
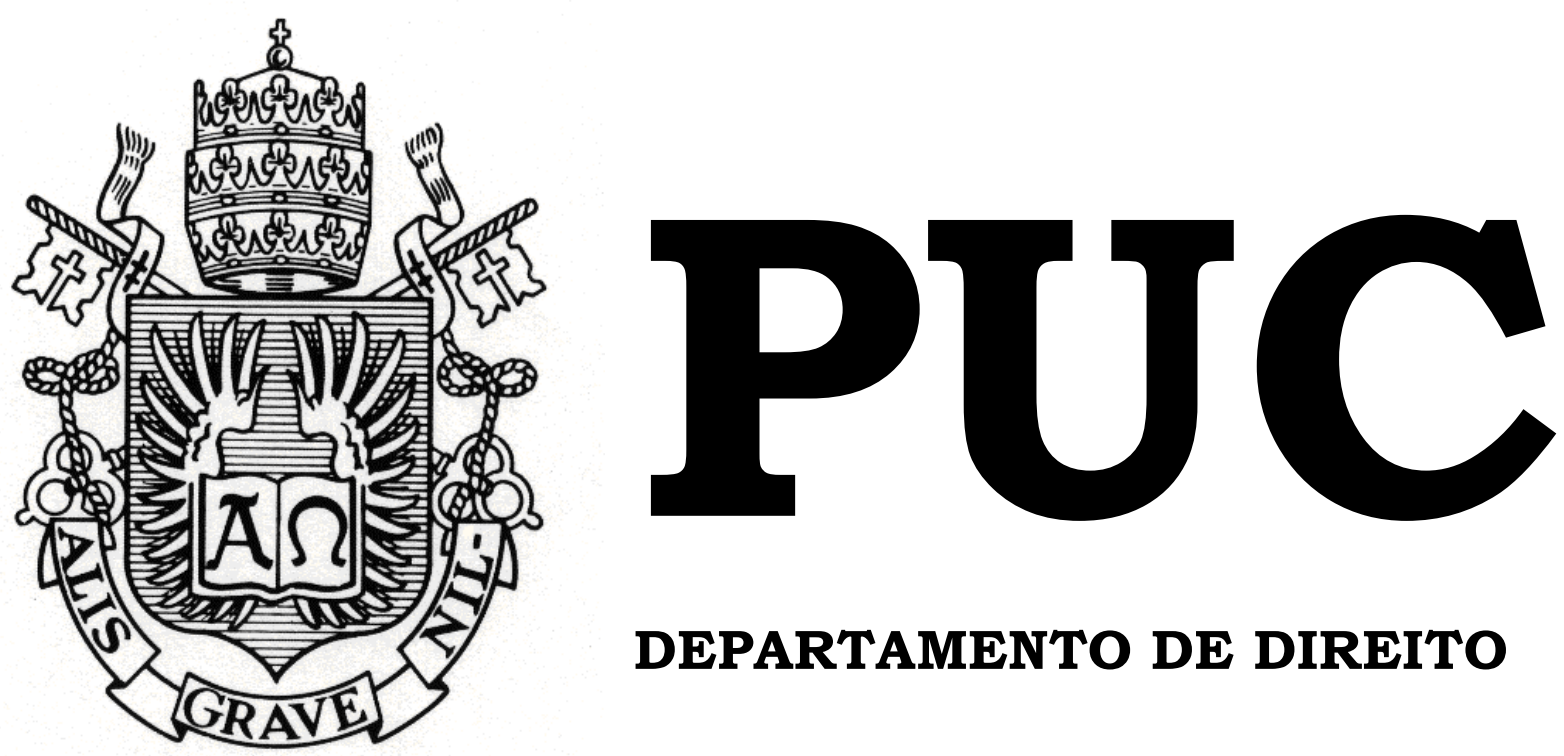

DEPARTAMENTO DE DIREITO

\title{
AUDIÊNCIA DE CUSTÓDIA: A HUMANIZAÇÃO DO PROCESSO PENAL ATRAVÉS DO OLHAR DO JUIZ
}

Por

GABRIELA TEIXEIRA DE ABREU RAPOSO

ORIENTADOR: BRENO MELARAGNO COSTA

2016.2

PONTIFÍCIA UNIVERSIDADE CATÓLICA DO RIO DE JANEIRO

RUA MARQUÊS DE SÃO VICENTE, 225 - CEP 22451-900

RIO DE JANEIRO - BRASIL 


\title{
AUDIÊNCIA DE CUSTÓdIA: A HUMANIZAÇÃO DO PROCESSO PENAL ATRAVÉS DO OLHAR DO JUIZ
}

\author{
por \\ GABRIELA TEIXEIRA DE ABREU RAPOSO
}

Monografia apresentada ao

Departamento de Direito da

Pontificia Universidade Católica do

Rio de Janeiro (PUC-Rio) para a

obtenção do Título de Bacharel em Direito.

Orientador: Breno Melaragno Costa

2016.2 


\section{AGRADECIMENTOS}

Primeiramente, à minha família em especial à minha mãe e ao meu pai pelo amor incondicional e incentivo, não somente nestes anos de faculdade, mas em todos os momentos da minha vida. Devo tudo a vocês!

À minha avó por ser o amor da minha vida, para sempre.

Ao mestre, Prof. Breno, pela confiança e orientação na elaboração deste trabalho. Meus agradecimentos pelos ensinamentos e o seu papel atuante no meu processo de formação profissional ao longo da faculdade.

À Dra. Muna Bastos pelo carinho, atenção, suporte e auxílio prestado no desenvolvimento deste trabalho. Meus sinceros agradecimentos por me proporcionar o conhecimento da realidade das Audiências de Custódias no Rio de Janeiro. Sem a sua colaboração e da equipe da Central da Audiência de Custódia, em especial a Equipe Multidisciplinar que exerce um belíssimo trabalho na vida de muitas pessoas, esta monografia não seria tão rica em detalhes.

À Dra. Adriana Gameiro agradeço às indicações das palestras oferecidas pela Defensoria Pública do Estado do Rio de Janeiro sobre as Audiências de Custódias, que foram de suma importância para a elaboração do presente trabalho. Além disso, agradeço pelo significativo papel que a sua atuação como profissional e o seu amor inspirador pela função exercida pela Defensoria Pública teve na minha formação não só como estudante, mas também como ser humano.

Às minhas amigas Sasha e Lu pela parceria e pelo apoio para que eu concluísse mais essa etapa na minha vida! 


\title{
RESUMO
}

\begin{abstract}
A realidade brasileira ilustra que a cultura do encarceramento corrobora para o quadro maquiavélico de superlotação do sistema penitenciário, instigando o recrudescimento do rigor punitivista do Poder Judiciário quanto a decretação imprópria da prisão cautelar, mais especificamente da prisão preventiva. O Projeto da Audiência de Custódia, arquitetado pelo Conselho Nacional de Justiça em 2015, e que hoje se encontra implementado em todas as capitais brasileiras, foi concebido como uma estratégia voltada para alterar o cenário da superpopulação carcerária, ante a percepção da responsabilidade do Poder Judiciário quanto ao excesso de presos provisórios nas cadeias. A Audiência de Custódia é uma ferramenta eficaz de combate à tortura, está prevista em tratados internacionais de direitos humanos ratificados pelo Brasil há décadas atrás e, mesmo assim, carece de legislação regulamentando o seu procedimento até os dias de hoje. Visa-se com o instituto jurídico da Audiência de Custódia, a humanização do processo penal através do olhar do juiz para o custodiado.
\end{abstract}

Palavras-Chave: Audiência de Custódia; Resolução nº 213 do CNJ; Estado Democrático de Direito; humanização do processo penal; cultura do encarceramento; prisão cautelar; direito à liberdade como regra; combate à tortura. 


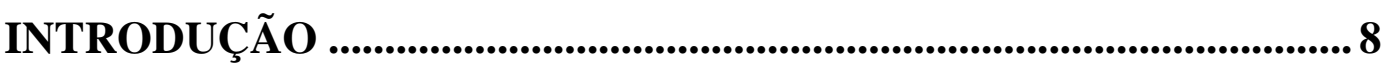

CAPÍTULO 1 - O SISTEMA PROCESSUAL ACUSATÓRIO, PENA PRIVATIVA DE LIBERDADE E O ESTADO DEMOCRÁTICO DE

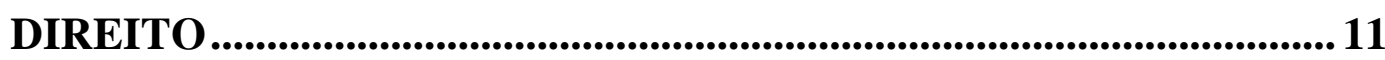

1.1. Noções gerais relacionadas à pena privativa de liberdade ................ 14

1.2. Bases constitucionais para o controle da legalidade e formalidade do

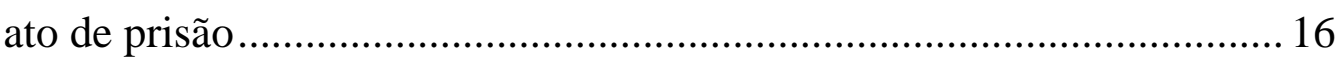

1.3. Concepções estruturais das medidas cautelares ................................. 18

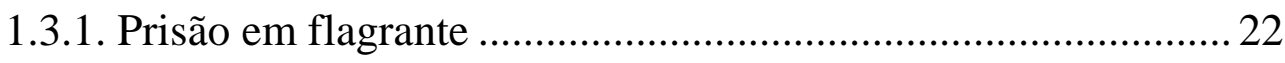

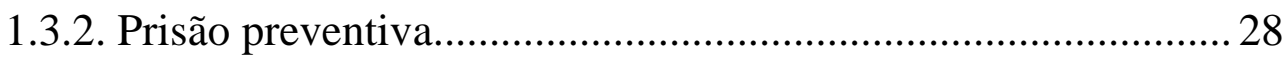

1.3.3. Medidas cautelares diversas da prisão ……………………….... 32

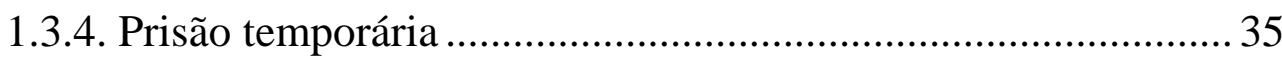

1.3.5. Prisão domiciliar como medida cautelar..................................... 39

1.3.6. Prisão como execução provisória de sentença condenatória confirmada em segunda instância ......................................................... 41

CAPÍTULO 2 - A CULTURA DO ENCARCERAMENTO EM MASSA, PRISÃO CAUTELAR E A REALIDADE BRASILEIRA .... 48

2.1. O desvio de finalidade do instituto da prisão cautelar........................ 49

2.2. Realidade carcerária brasileira ....................................................... 52

CAPÍTULO 3 - AUDIÊNCIA DE CUSTÓdia E AS SUAS DIRETRIZES NOS TRATADOS INTERNACIONAIS ..........................55

3.1. Audiência de Custódia e o direito comparado.....................................58

3.2. A implementação da Audiência de Custódia no Brasil ....................... 62

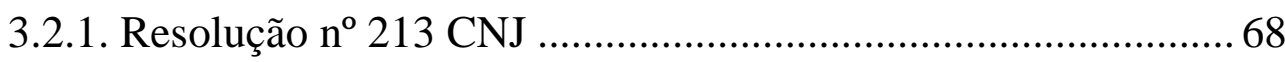

3.3. Aspectos gerais da Audiência de Custódia......................................... 72

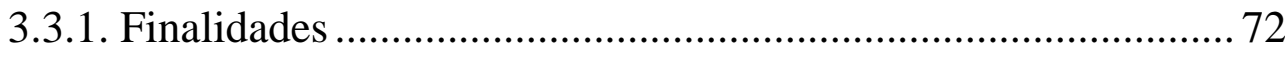

3.3.1.1. Preservar a integridade física e psíquica do conduzido .... 73

3.3.1.2. Analisar a legalidade da prisão............................................ 76 
3.3.1.3. Medidas cautelares de ordem pessoal .................................. 77

3.3.2. Princípios assegurados na Audiência de Custódia .................... 78

3.3.2.1. Presunção de Inocência ...................................................... 78

3.3.2.2. Dignidade da Pessoa Humana ............................................... 79

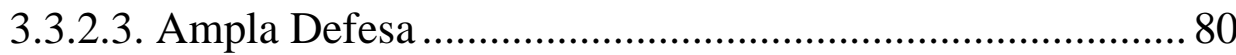

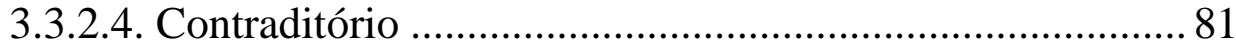

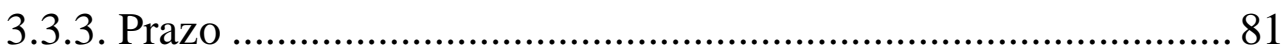

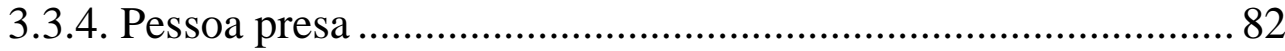

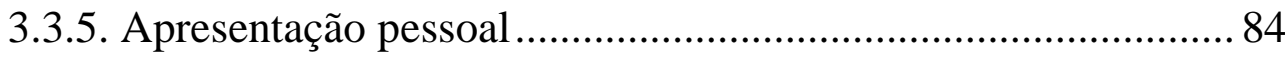

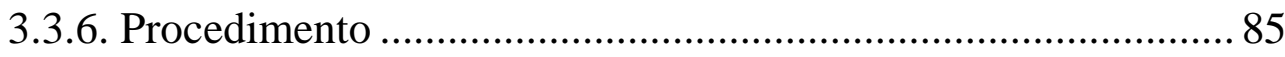

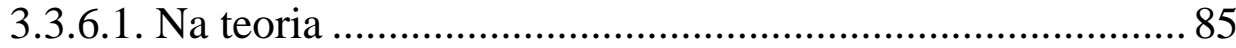

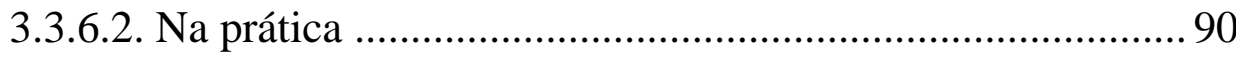

3.3.7. Consequência jurídica da não realização da Audiência de

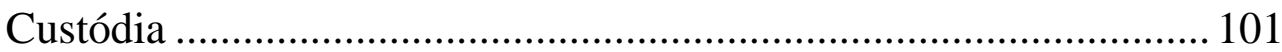

3.4. Críticas e dificuldades de implementação........................................... 103

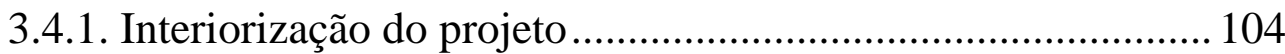

3.4.2. Realização diária das Audiências de Custódia ........................ 105

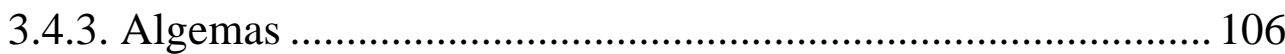

3.4.4. Estrutura médica e multidisciplinar .......................................... 107

3.4.5. Inércia do Poder Legislativo ................................................... 107

3.4.6. Deficiência na apuração dos relatos de tortura ......................... 108

3.4.7. Perfil social dos custodiados................................................... 110

3.4.8. Resistência social e midiática quanto a implementação da Audiência de Custódia ................................................................... 111

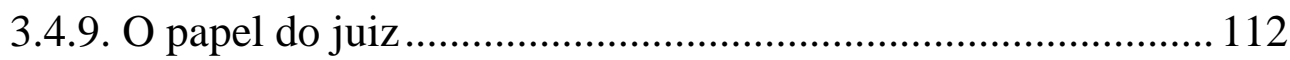

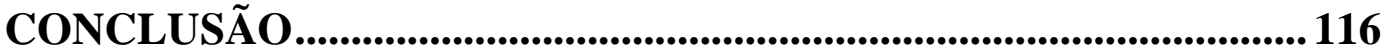

REFERÊNCIAS BIBLIOGRÁFICAS ............................................... 120 


\section{LISTA DE ABREVIAÇÕES}

ADC - Ação Direta de Constitucionalidade

ADI - Ação Direta de Inconstitucionalidade

ADPF - Arguição de Descumprimento de Preceito Fundamental

APF - Auto de Prisão em Flagrante

APL - Apelação

ART - Artigo

CF - Constituição Federal

CNJ - Conselho Nacional de Justiça

$\mathrm{CP}$ - Código Penal

CPP - Código de Processo Penal

HC - Habeas Corpus

IML - Instituto Médico Legal

TJ - Tribunal de Justiça

TRF - Tribunal Regional Federal

MP - Ministério Público

STF - Supremo Tribunal Federal

STJ - Supremo Tribunal de Justiça 
Serei feliz se puder provocar alguma vez esse frêmito pelo qual as almas sensiveis respondem à voz dos defensores da humanidade!

Cesare Beccaria 


\section{INTRODUÇÃO}

Antes de iniciar a leitura do presente trabalho acadêmico, ou de qualquer outra obra sobre direito processual penal, é necessário afastar a ótica do homem comum sobre o direito penal, movida pelas emoções, nutrida pelas experiências como cidadão-vítima da violência urbana e influenciada pelo discurso manipulador da mídia. Somente assim, será possível analisar criticamente a visão do Estado acerca da matéria, como pessoa jurídica de direito público, que possui como finalidade a administração de políticas públicas democráticas que atendam os anseios de toda a sociedade civil.

É de extrema importância também ter-se em mente que a Constituição de 1988 é a solidificação de um estado democrático destinado a garantir valores supremos de uma sociedade pautada na liberdade. Assim, todos os dispositivos infraconstitucionais devem ser interpretados de modo a garantir máxima efetividade das normas constitucionais devendo preferirse interpretações que reconheçam a maior eficácia dos direitos fundamentais previstos na Lei Maior, principalmente no que se refere às leis processuais penais. O código de processo penal foi instituído em 1941 com influências autoritárias do período ditatorial, apesar de pontuais alterações legislativas realizadas posteriormente ao longo dos anos, ainda se evidencia contradições com os princípios democráticos instituídos pela Constituição.

Dito isto, ressalta-se que a presente monografia imprime um prisma sistemático crítico do processo penal a partir dos fundamentos democráticos do sistema acusatório, enfatizando os princípios assentados na Constituição Federal e nos tratados internacionais ratificados pelo Brasil, que suscitaram o instituto jurídico da Audiência de Custodia. 
Esta obra desempenha o fim de aperfeiçoar o conhecimento sobre temas relevantes e controversos a respeito da Audiência de Custódia, a sua relação direta com a prisão preventiva, a cultura do encarceramento e a superpolução carcerária.

O primeiro capítulo do presente trabalho discorre sobre a relação entre o Estado Democrático de Direito, pautado no sistema processual acusatório, e as penas privativas de liberdade. São abordados os temas das prisões cautelares, destacando-se a prisão em flagrante e a prisão preventiva que se correlacionam frontalmente com o instituto da Audiência de Custódia. Merece destaque o fato de que, apesar de não ser uma modalidade de prisão cautelar, a prisão como execução provisória de sentença condenatória confirmada em segunda instância recebe breves exposições na Monografia, pois o tema se encontra em voga no cenário jurídico, vez que foi admitida a partir de uma recente decisão do STF, contrariando todos os precedentes até então estabelecidos.

O segundo capítulo pronuncia-se a respeito da caótica realidade carcerária que muito se deve a cultura do encarceramento na qual não só o Poder Judiciário, mas toda a sociedade se encontra inserida nos dias de hoje. Evidencia-se estatisticamente que o uso indiscriminado das prisões cautelares, mais especificamente no que se diz respeito ao instituto da prisão preventiva, é o grande responsável para o diagnóstico do exorbitante número de pessoas encarceradas, que segue uma tendência de crescimento continuo e acelerado.

O terceiro capítulo aborda a temática da Audiência de Custódia propriamente dita, analisando de forma crítica, seus objetivos, sua relação com o direito comparado no cenário internacional, a previsão de suas diretrizes nos Tratados Internacionais ratificados pelo Brasil, os intentos (insuficientes) de ordem legislativa e como a implantação do instituto vem ocorrendo de forma gradativa e tímida no país diante as dificuldades 
existentes. Evidencia-se neste capítulo também, a exposição detalhada acerca do procedimento adotado pela Central de Audiência de Custódia localizada no Tribunal de Justiça do Estado do Rio de Janeiro e a comparação com outros estados.

Visa-se com a monografia o fomento do debate acadêmico sobre a Audiência de Custódia instituto este que, apesar da sua recepção pelo ordenamento jurídico interno ter ocorrido há mais de duas décadas com a ratificação dos tratados internacionais, carece de regulamentação legislativa até os dias de hoje e de estudos mais aprofundados no mundo forense.

Objetiva-se também com o presente trabalho, a partir de uma visão democrática lapidada pelo princípio da máxima efetividade da Constituição Federal, romper o falso paradigma sustentado pela cultura do encarceramento de que o direito penal é o meio de contenção da violência urbana advinda dos desvios e da ineficiência das políticas públicas sociais.

Ressalta-se que por inexistir regulamentação proveniente do Poder Legislativo a respeito do procedimento da Audiência de Custódia e pelo tema, infelizmente, não se encontrar ainda como destaque na pauta das discussões doutrinárias, os dados fornecidos por órgãos do Poder Judiciário, como o Conselho Nacional de Justiça (CNJ), a Central de Audiência de Custódia localizada no Tribunal de Justiça do Estado do Rio de Janeiro e as palestras oferecidas pela Defensoria Pública do Estado do Rio de Janeiro foram de suma importância para o desenvolver da presente monografia com elementos informacionais realísticos, verídicos e estatísticos. 


\section{CAPÍTULO 1 - O SISTEMA PROCESSUAL ACUSATÓRIO, PENA PRIVATIVA DE LIBERDADE E O ESTADO DEMOCRÁTICO DE DIREITO}

O sistema processual penal é a instrumentalização da função do Estado, através da consolidação de normas e princípios, que definem as regras a serem utilizadas na aplicação do direito penal, por meio de um processo.

Segundo valiosos ensinamentos do jurista Paulo Rangel:

Sistema Processual Penal é o conjunto de princípios e regras constitucionais, de acordo com o momento político de cada Estado, que estabelece as diretrizes a serem seguidas para a aplicação do direito penal (...) através do processo, que deve se revestir, em princípio, de duas formas: a inquisitiva e a acusatória ${ }^{1}$.

A adoção do sistema acusatório configura um Estado Democrático de Direito pois garante os direitos fundamentais e individuais dos cidadãos contra o arbítrio do Estado. Já o sistema inquisitivo legitima a concentração do poder nas mãos de um Estado totalitário.

Conforme disciplina Hélio Tornaghi:

O que distingue a forma acusatória da inquisitória é o seguinte: na primeira, as três funções de acusar, defender e julgar estão atribuídas a três órgãos diferentes: acusador, defensor e juiz; na segunda, as três funções estão confiadas ao mesmo órgão. $\mathrm{O}$ inquisidor deve proceder espontaneamente e suprir as necessidades da defesa. O réu é tratado como objeto do processo e não como sujeito, isso é, como pessoa titular do direito de defesa; nada pode exigir².

Atualmente não é possível encontrar mais o sistema acusatório puro ou o sistema acusatório inquisitivo puro. O que configura se um Estado

\footnotetext{
${ }^{1}$ RANGEL, Paulo. Direito Processual Penal. $7^{\mathrm{a}}$ ed. Rio de Janeiro: Editora Lumen Juris, 2003. p. 45.

2 TORNAGHI, Hélio. Instituições de Direito Processual Penal. $2^{\mathrm{a}}$ ed. v. II, São Paulo: Saraiva, 1997. p. 1-2.
} 
adota o sistema inquisitivo ou o acusatório é a predominância de um, em relação ao outro, na lei pátria de cada país.

Apesar de não ter sido esclarecido de forma expressa, o sistema adotado pela Constituição Federal brasileira foi o sistema acusatório pois, de acordo com os princípios estabelecidos pela Lei Maior, mais precisamente o princípio do contraditório (Art. $5^{\circ}, \mathrm{LV}$ CF) e do juiz natural (Art. 5º, LIII CF), vislumbra-se a separação em órgãos distintos do papel acusatório, julgador e defensor. A gestão da prova, ou seja, a produção das provas é conferida às partes, enquanto o juiz, imparcial, é mero expectador.

O ônus da produção da prova, é do órgão acusador. É conferido ao réu direito à ampla defesa e ao contraditório durante todo o processo penal. Cabe ao juiz (juiz expectador), ao final da prestação jurisdicional, valorar as provas apresentadas por ambas as partes e deliberar, conforme a verdade processual dos fatos, acerca da condenação ou não do réu.

Está ratificado na Constituição da República Federativa do Brasil que o fundamento do Estado Democrático de Direito é a dignidade da pessoa humana, descrito no Art. $1^{\circ}$, III $\mathrm{CF}^{3}$.

Quando a ordem jurídica justa é rompida por um indivíduo que pratica um crime, nasce para o Estado a pretensão punitiva que, por meio de seu órgão acusador representado pela figura do Ministério Público ${ }^{4}$, pode pleitear o cerceamento da liberdade do indivíduo como uma forma de restabelecer a manutenção da ordem e a punição para aquele que a infringiu.

Conforme disciplina Afranio Silva Jardim:

\footnotetext{
${ }^{3}$ Art. $1^{\circ} \mathrm{CF}$ - A República Federativa do Brasil, formada pela união indissolúvel dos Estados e Municípios e do Distrito Federal, constitui-se em Estado Democrático de Direito e tem como fundamentos:

III - a dignidade da pessoa humana.

${ }^{4}$ (...) Há um próprio órgão próprio, criado pelo Estado, para a propositura da ação. Na França, em fins do século XIV, surgiram os les procureurs du roi (procuradores do rei), dando origem ao Ministério Público. Assim, o titular da ação penal pública passou a ser o Ministério Público (...). RANGEL, 2003, p. 49.
} 
(...) pretensão punitiva trata-se de uma exigência no sentido de que prevaleça o interesse do autor da ação na punição do réu, ordinariamente em detrimento de sua aspiração de manter a liberdade ou, ao menos, o seu estado de inocência. Desta forma, a pretensão punitiva é fato processual, praticado em juízo através do exercício da ação penal condenatória ${ }^{5}$.

Desta forma, em um Estado Democrático de Direito que adota o sistema processual penal acusatório, embora o Estado tenha o poder/dever de aplicar a sanção aquele que violando o ordenamento jurídico praticou um ilícito, a pena somente deverá ser aplicada após um devido processo legal, segundo Art. $5^{\circ}$, LIV CF ${ }^{6}$.

O devido processo legal é um supra princípio do qual decorrem todos os demais princípios processuais penais constitucionais. $\mathrm{O}$ devido processo legal assegura o cumprimento de todas as formalidades do processo ("regras do jogo"); formalidades estas que são as garantias de um processo justo. Caso não sejam observadas as "regras do jogo" no trâmite do processo conforme consta na lei, significa que houve manifesta ilegalidade em seu transcorrer sendo este apenado com nulidade.

As limitações ao poder Estatal são exercidas através do cumprimento do devido processo legal, no qual deverão ser respeitadas todas as formalidades, direitos e garantias constitucionais de um processo justo, concedendo a paridade de armas entre acusação e defesa por meio do princípio do contraditório e ampla defesa ${ }^{7}$, além do princípio da presunção da inocência ${ }^{8}$ e do juiz natural ${ }^{9}$, consagrados na constituição Federal.

\footnotetext{
${ }^{5}$ JARDIM, Afranio Silva. Direito Processual Penal. $7^{\text {a }}$ ed. Rio de Janeiro: Editora Forense, 1999. p. 35 .

${ }^{6}$ Art. $5^{\circ} \mathrm{CF}$ - Todos são iguais perante a lei, sem distinção de qualquer natureza, garantindo-se aos brasileiros e aos estrangeiros residentes no País a inviolabilidade do direito à vida, à liberdade, à igualdade, à segurança e à propriedade, nos termos seguintes:

LIV - ninguém será privado da liberdade ou de seus bens sem o devido processo legal.

${ }^{7}$ Art. $5^{\circ} \mathrm{CF}(\ldots)$

LV - aos litigantes, em processo judicial ou administrativo, e aos acusados em geral são assegurados o contraditório e ampla defesa, com os meios e recursos a ela inerentes;

${ }^{8}$ Art. $5^{\circ} \mathrm{CF}(\ldots)$

LVII - ninguém será considerado culpado até o trânsito em julgado de sentença penal condenatória;

${ }^{9}$ Art. $5^{\circ} \mathrm{CF}$ (...)
} 
Conforme elucida Guilherme de Souza Nucci:

O sistema processual penal, com seus princípios constitucionais, está interligado ao penal e seus princípios constitucionais. Portanto, deve-se visualizar o cenário único das ciências criminais, regidas que são pelos princípios morais da dignidade da pessoa humana e do devido processo legal ${ }^{10}$.

Visa-se discorrer neste capítulo, uma noção geral sobre as prisões a partir de uma abordagem constitucional de um Estado Democrático, a respeito de seus fundamentos e formalidades. Além do esclarecimento das modalidades das prisões previstas na legislação e das medidas cautelares alternativas a prisão.

\title{
1.1. Noções gerais relacionadas à pena privativa de liberdade
}

A partir do momento em que o homem, até então em estado selvagem, passou a viver em comunidade, adotou-se o sistema de aplicação de penas todas as vezes que as regras da sociedade eram violadas.

Conforme leciona Cesare Beccaria quanto a origem das penas e do direito de punir:

\begin{abstract}
Ninguém faz graciosamente o sacrifico de uma parte de sua liberdade apenas visando ao bem público. (...) os primeiros homens, até então em estado selvagem, foram forçados a agrupar-se (...) cansados de uma liberdade cuja incerteza de conservá-la tornava inútil, sacrificaram uma parte e dela para usufruir do restante com mais segurança. A soma dessas partes de liberdade, assim sacrificadas ao bem geral, constituiu a soberania da nação e aquele que foi encarregado como depositário dessas liberdades foi proclamado soberano. (...) não era suficiente a formação desse depósito; era necessário protege-lo contra as usurpações de cada partícula pois a tendência do homem é tão forte para o despotismo que ele procura, incessantemente, não só retirar da massa comum a sua parte de liberdade como também usurpar a dos outros. Eram necessários meios poderosos para sufocar esse espirito despótico (...). Tais meios foram as penas estabelecidas contra os que infringiam as leis ${ }^{11}$.
\end{abstract}

LIII - ninguém será processado nem sentenciado senão pela autoridade competente.

${ }^{10}$ NUCCI, Guilherme de Souza. Prisão e Liberdade. $4^{\mathrm{a}}$ ed. Rio de Janeiro: Editora Forense, 2014. p. 15 .

${ }^{11}$ BECCARIA, Cesare. Dos delitos e das penas. $7^{\mathrm{a}}$ ed. Editora Martin Claret., 2013. p. 16-17. 
Desde a Antiguidade até meados do século XVIII, as penas judicias constituíam-se em castigos severos como torturas, banimento e penas de morte, no qual o corpo do agente infrator respondia pelos atos praticados.

O período iluminista foi tido como o marco inicial para a mudança desta mentalidade na aplicação das penas existindo hoje uma preocupação maior com a cominação de punições justas, com a proporcionalidade entre pena e dano causado, com a integridade física e mental do infrator e com o princípio da dignidade da pessoa humana. ${ }^{12}$

O Art. 32 do código pena $1^{13}$ disciplina as espécies de penas previstas no ordenamento jurídico brasileiro: pena privativa de liberdade, restritiva de direitos e multa.

Segundo Manuel Pedro Pimentel:

A pena de prisão teve sua origem nos mosteiros de Idade Média, como punição imposta aos monges os clérigos faltosos, fazendo com que se recolhessem às suas celas para se dedicarem, em silencio, à meditação e se arrependerem da falta cometida, reconciliando-se assim com Deus ${ }^{14}$.

A pena privativa de liberdade é a mais severa das penas previstas na nossa legislação atual e consiste na supressão da liberdade de deslocamento do indivíduo.

A prisão pode ser anterior ou posterior à uma sentença condenatória transitada em julgado. Quando se trata de uma prisão pós sentença condenatória sob a qual não há mais recurso cabível, estamos diante de uma prisão-pena. Já, quando se trata de uma prisão anterior à uma sentença condenatória, podemos estar nos referindo à uma prisão cautelar ou, conforme acordão recente do $\mathrm{STF}^{15}$, uma prisão que consiste na execução

\footnotetext{
12 GRECO, Rogério. Curso de Direito Penal Parte e Geral. v. I. $15^{\mathrm{a}}$ ed. Niterói, Rio de Janeiro: Editora Impetus, 2013. p. 473.

${ }^{13}$ Art. 32 CP: As penas são: I - privativas de liberdade; II - restritivas de direitos; III - de multa.

${ }^{14}$ PIMENTEL, Manoel Pedro. O crime e a pena na atualidade. 1983. p. 132.

${ }^{15}$ STF, HC n. 126.292. Rel. Ministro Teori Zavascki, Brasília, 17 fev. 2016.
} 
provisória de sentença penal condenatória confirmada em segunda instância.

\subsection{Bases constitucionais para o controle da legalidade e formalidade do ato de prisão}

Os institutos penais e processuais penais devem ser interpretados de forma a garantir a máxima efetividade dos princípios fundamentais estabelecidos na Constituição Federal, principalmente em consonância com o princípio da dignidade da pessoa humana.

A Constituição Federal disciplina no caput do seu Art. $5^{\circ}$, que o direito à liberdade é inviolável. Contudo, quando confrontamos os princípios da liberdade individual e o da segurança pública, vislumbramos um antagônico conflito entre ambos ${ }^{16}$.

Motivo pelo o qual, leciona Pedro Lenza acerca da temática:

Os direitos fundamentais não são absolutos (relatividade), havendo, muitas vezes, no caso concreto, confronto, conflito de interesses. A solução ou vem discriminada na própria Constituição (...), ou caberá ao interprete, ou magistrado, no caso concreto, decidir qual direito deverá prevalecer, levando em consideração a regra da máxima observação dos direitos fundamentais envolvidos ${ }^{17}$.

O direito fundamental à liberdade de ir e vir do indivíduo pode ser flexibilizado para a aplicação de uma pena privativa de liberdade após o trânsito em julgado de uma decisão definitiva, observado o devido Processo Legal, ou para a aplicação de uma prisão cautelar.

A prisão do acusado deve ser sempre considerada a ultima ratio ou seja, trata-se de uma medida excepcional a deve ser tomada somente em casos de real conveniência. Quando necessária, deve ser devidamente

\footnotetext{
${ }^{16}$ Art. $5^{\circ} \mathrm{CF}$ - Todos são iguais perante a lei, sem distinção de qualquer natureza, garantindo-se aos brasileiros e aos estrangeiros residentes no País a inviolabilidade do direito à vida, à liberdade, à igualdade, à segurança e à propriedade, nos termos seguintes.

${ }^{17}$ LENZA, Pedro. Direito Constitucional Esquematizado. 12a ed. Editora Saraiva, 2008. p. 590.
} 
formalizada conforme a legislação e substancialmente motivada. Assim, a liberdade individual é a regra e a prisão cautelar, a exceção.

O Legislador Constituinte estruturou os direitos e garantias fundamentais previstos no Art. $5^{\circ}$ da Constituição Federal de modo a assegurar o controle pleno da legalidade da prisão. O texto constitucional visa a eficácia da preservação dos direitos elementares dos indivíduos contra possíveis abusos e arbítrios do Estado, legitimando assim um efetivo Estado Democrático de Direito.

A Constituição consagra em seu Art. $5^{\circ}$, LXI CF e no Art. 93, IX CF que a prisão somente poderá ser efetuada mediante situação de flagrância, devido a sua urgência, ou por decisão essencialmente fundamentada pelo órgão competente ${ }^{18}$.

Destaca ainda que a prisão de qualquer pessoa e o local em que se encontra deverá ser imediatamente comunicado a família do preso e ao juiz competente segundo o Art. $5^{\circ}$, LXII CF ${ }^{19}$.

Outro aspecto importante diz respeito a obrigatoriedade do indivíduo de obter informações sobre os seus direitos no momento da prisão, como por exemplo o seu direito de defesa de permanecer em silêncio, previsto no Art. $5^{\circ}$, LXIII CF ${ }^{20}$.

A Constituição no Art. $5^{\circ}$, LXIV enaltece o direito do preso de obter o conhecimento dos responsáveis pela sua prisão e pelo interrogatório policial o que facilita uma possível responsabilização das autoridades que,

\footnotetext{
18 Art. 5 , LXI - ninguém será preso senão em flagrante delito ou por ordem escrita e fundamentada de autoridade judiciária competente, salvo nos casos de transgressão militar ou crime propriamente militar, definidos em lei.

Art. 93, IX - todos os julgamentos dos órgãos do Poder Judiciário serão públicos, e fundamentadas todas as decisões, sob pena de nulidade, podendo a lei limitar a presença, em determinados atos, às próprias partes e a seus advogados, ou somente a estes, em casos nos quais a preservação do direito à intimidade do interessado no sigilo não prejudique o interesse público à informação;

19 Art. $5^{\circ}$, LXII - a prisão de qualquer pessoa e o local onde se encontre serão comunicados imediatamente ao juiz competente e à família do preso ou à pessoa por ele indicada.

${ }^{20}$ Art. $5^{\circ}$, LXIII - o preso será informado de seus direitos, entre os quais o de permanecer calado, sendo-lhe assegurada a assistência da família e de advogado.
} 
por ventura, venham a praticar algum ato ilícito durante estes procedimentos ${ }^{21}$.

O controle da autoridade judiciaria quanto as formalidades da prisão em flagrantes são reconhecidas pela Constituição Federal de modo que prevê o Art. $5^{\circ} \mathrm{LXV}$ que a prisão viciada de ilegalidade deve ser relaxada pelo magistrado imediatamente ${ }^{22}$.

Nos casos em que a prisão em flagrante é legal, porém é cabível a concessão da liberdade provisória, estabelece a Lei Pátria em seu Art. $5^{\circ}$ LXVI que o direito à liberdade provisória é impreterível ${ }^{23}$.

A Lei Maior assegura o princípio da presunção de inocência, reafirmando o caráter excepcional da prisão anterior a sentença penal sem, porém, obstar a legitimidade da prisão cautelar no interim da investigação criminal ou no decorrer do processo ${ }^{24}$.

A Constituição ainda torna imperiosa a obrigação do Estado prestar assistência gratuita jurídica a todos aqueles que não possuírem recursos para prover uma defesa técnica e dela necessitarem ${ }^{25}$.

Em suma, há fundamentos constitucionais que solidificam a legalidade da sistemática da prisão assim como a exigência das suas formalidades e consubstanciam este instituto como sendo de caráter excepcional, uma vez que a liberdade é a regra no Estado Democrático de Direito.

\subsection{Concepções estruturais das medidas cautelares}

\footnotetext{
${ }^{21}$ Art. $5^{\circ}$, LXIV - o preso tem direito à identificação dos responsáveis por sua prisão ou por seu interrogatório policial.

${ }^{22}$ Art. $5^{\circ}$, LXV - a prisão ilegal será imediatamente relaxada pela autoridade judiciária.

${ }^{23}$ Art. $5^{\circ}$, LXVI - ninguém será levado à prisão ou nela mantido, quando a lei admitir a liberdade provisória, com ou sem fiança.

${ }^{24}$ Art. $5^{\circ}$, LVII - ninguém será considerado culpado até o trânsito em julgado de sentença penal condenatória.

${ }^{25}$ Art. $5^{\circ}$, LXXIV - o Estado prestará assistência jurídica integral e gratuita aos que comprovarem insuficiência de recursos.
} 
Medidas cautelares são providências emergentes que servem para garantir a eficiência do processo e visam minimizar possíveis prejuízos advindos do lapso temporal em que o mesmo se deflagra.

Conforme leciona Antonio Scarance Fernandes:

No intervalo entre o nascimento da relação jurídica processual e a obtenção do provimento final, existe sempre o risco de sucederem eventos que comprometam a atuação jurisdicional ou afetem profundamente a eficácia e utilidade do julgado. Há então a necessidade de medidas cautelares que eliminem ou amenizem esse perigo $^{26}$.

Em linhas gerais, existem dois pressupostos essenciais para a aplicação das medidas cautelares: periculum in mora e fumus boni iuris.

O fumus boni iuris, ou fumaça do bom direito, consiste na presença de indicativos da existência do crime e da autoria. O periculum in mora, ou periculum libertatis, constitui o perigo que a demora no julgamento possa resultar, interferindo na justa solução da causa ou na aplicação da lei penal.

Acerca da temática afirmam com muita propriedade Araújo Cintra, Ada Pellegrini e Cândido Dinamarco:

(...) a atividade cautelar foi preordenada para evitar que o dano oriundo da inobservância do direito fosse agravado pelo inevitável retardamento do remédio jurisdicional (periculum in mora). $\mathrm{O}$ provimento cautelar funda-se antecipadamente na hipótese de um futuro provimento jurisdicional favorável ao autor (fumus boni iuris) ${ }^{27}$.

Conforme preceitua o Art. 282 CPP, os requisitos para a aplicação das medidas cautelares concentram-se basicamente na necessidade e adequação ${ }^{28}$.

\footnotetext{
${ }^{26}$ FERNANDES, Antonio Scarance. Processo Penal Constitucional. $3^{\text {a }}$ ed. Editora Revista dos Tribunais.1999. p. 301.

${ }^{27}$ CINTRA, Antônio; PELLEGRINI, Ada e DINAMARCO, Cândido. Teoria Geral do Processo. $3^{\text {a }}$ ed. São Paulo: Revista dos Tribunais, 1981. p. 280.

${ }^{28}$ Art. 282. As medidas cautelares previstas neste Título deverão ser aplicadas observando-se a: I - necessidade para aplicação da lei penal, para a investigação ou a instrução criminal e, nos casos expressamente previstos, para evitar a prática de infrações penais;
} 
O princípio constitucional da presunção de inocência ${ }^{29}$, legado do Estado Democrático de Direito, pressupõe que ninguém será considerado culpado antes do trânsito em julgado, o que justifica a real necessidade como condição para a decretação de qualquer medida cautelar. Já, com relação ao requisito da adequabilidade, vincula-se o princípio da proporcionalidade e o da individualização da pena $^{30}$. Nesse sentido, o magistrado na análise do caso concreto deve avaliar as circunstâncias do fato e as condições pessoais do acusado para poder fixar as medidas cautelares cabíveis.

A prisão cautelar é a medida cautelar mais severa e a mais conhecida na seara processual.

O Art. $319 \mathrm{CPP}^{31}$ elenca outras medidas cautelares diversas da prisão que envolvem restrições à liberdade individual como a proibição de acesso a determinados lugares e monitoramento eletrônico.

II - adequação da medida à gravidade do crime, circunstâncias do fato e condições pessoais do indiciado ou acusado.

$\S 1$ o As medidas cautelares poderão ser aplicadas isolada ou cumulativamente.

$\S 20$ As medidas cautelares serão decretadas pelo juiz, de ofício ou a requerimento das partes ou, quando no curso da investigação criminal, por representação da autoridade policial ou mediante requerimento do Ministério Público.

§ 3o Ressalvados os casos de urgência ou de perigo de ineficácia da medida, o juiz, ao receber o pedido de medida cautelar, determinará a intimação da parte contrária, acompanhada de cópia do requerimento e das peças necessárias, permanecendo os autos em juízo.

$\S 4$ o No caso de descumprimento de qualquer das obrigações impostas, o juiz, de ofício ou mediante requerimento do Ministério Público, de seu assistente ou do querelante, poderá substituir a medida, impor outra em cumulação, ou, em último caso, decretar a prisão preventiva (Art. 312, parágrafo único).

§ 5o O juiz poderá revogar a medida cautelar ou substituí-la quando verificar a falta de motivo para que subsista, bem como voltar a decretá-la, se sobrevierem razões que a justifiquem.

$\S 6$ o A prisão preventiva será determinada quando não for cabível a sua substituição por outra medida cautelar (Art. 319).

${ }^{29}$ Art. $5^{\circ}$, LVII CF: ninguém será considerado culpado até o trânsito em julgado de sentença penal condenatória;

${ }^{30}$ Art. $5^{\circ}$, XLVI CF: ninguém será levado à prisão ou nela mantido, quando a lei admitir a liberdade provisória, com ou sem fiança;

${ }^{31}$ Art. 319 CPP - São medidas cautelares diversas da prisão:

I - comparecimento periódico em juízo, no prazo e nas condições fixadas pelo juiz, para informar e justificar atividades;

II - proibição de acesso ou frequência a determinados lugares quando, por circunstâncias relacionadas ao fato, deva o indiciado ou acusado permanecer distante desses locais para evitar o risco de novas infrações;

III - proibição de manter contato com pessoa determinada quando, por circunstâncias relacionadas ao fato, deva o indiciado ou acusado dela permanecer distante; 
Cabe ressaltar que dentre as medidas cautelares, o magistrado deve optar primeiramente pela aplicação de alguma das medidas previstas no código processual penal diferentes da prisão. E somente se estas se demonstrarem insuficiente é que deve o juiz aplicar a medida mais gravosa que consiste no recolhimento da pessoa ao cárcere.

A prisão cautelar é a privação da liberdade do indivíduo, antes da sentença proferida.

A Constituição Federal consagra vários princípios fundamentais em seu Art. $5^{\circ}$ que amparam a prisão cautelar. O primeiro deles é o princípio da decisão fundamentada ${ }^{32}$ destacando que toda a prisão, inclusive de natureza cautelar, deve ser decretada mediante ordem escrita e fundamentada pela autoridade judiciaria competente.

Outro princípio previsto pela lei pátria, que versa sobre a prisão cautelar, é o da presunção de inocência ${ }^{33}$ que disciplina que o réu possui status de inocente até o trânsito em julgado da sentença penal condenatória. Este princípio, espinha dorsal que sustenta o processo penal democrático, ampara três aspectos processuais penais: o ônus da prova é da acusação, indubio pro réu (valoração da prova em benefício do réu em caso de dúvida) e a forma de tratamento do imputado ao longo do processo (o

IV - proibição de ausentar-se da Comarca quando a permanência seja conveniente ou necessária para a investigação ou instrução;

$\mathrm{V}$ - recolhimento domiciliar no período noturno e nos dias de folga quando o investigado ou acusado tenha residência e trabalho fixos;

VI - suspensão do exercício de função pública ou de atividade de natureza econômica ou financeira quando houver justo receio de sua utilização para a prática de infrações penais;

VII - internação provisória do acusado nas hipóteses de crimes praticados com violência ou grave ameaça, quando os peritos concluírem ser inimputável ou semi-imputável (Art. 26 do Código Penal) e houver risco de reiteração;

VIII - fiança, nas infrações que a admitem, para assegurar o comparecimento a atos do processo, evitar a obstrução do seu andamento ou em caso de resistência injustificada à ordem judicial;

IX - monitoração eletrônica.

§ 4o A fiança será aplicada de acordo com as disposições do Capítulo VI deste Título, podendo ser cumulada com outras medidas cautelares.

32 Art. $5^{\circ}$, LXI CF: ninguém será preso senão em flagrante delito ou por ordem escrita e fundamentada de autoridade judiciária competente, salvo nos casos de transgressão militar ou crime propriamente militar, definidos em lei.

${ }^{33}$ Art. $5^{\circ}$, LVII CF - ninguém será considerado culpado até o trânsito em julgado de sentença penal condenatória; 
magistrado deve enxergar o réu como um possível inocente e não como um provável culpado).

A prisão cautelar se trata de uma medida que visa resguardar o processo e não o direito material discutido neste.

Conforme leciona Nucci:

A prisão pena advém da imposição da sentença condenatória, com trânsito em julgado. A prisão cautelar é fruto da necessidade de se obter uma investigação ou instrução criminal produtiva, eficiente e livre de interferências. Embora ambas provoquem a segregação do indiciado ou acusado, a primeira constitui efetiva sanção penal; a segunda não passa de uma medida de cautela, com o fim de assegurar algo ${ }^{34}$.

São espécies de prisão cautelar: prisão em flagrante, prisão preventiva, prisão temporária e prisão domiciliar como medida cautelar.

Passemos agora a analisar cada uma das modalidades de prisão cautelar realizando uma comparação crítica a respeito da sistemática dos diversos institutos processuais penais que cerceiam o direito à liberdade individual e o os preceitos constitucionais que fundamentam o Estado Democrático de Direito.

\subsubsection{Prisão em flagrante}

Conforme ensinamentos do jurista Fernando Capez:

Prisão em flagrante é, portanto, medida restritiva de liberdade, de natureza cautelar e processual, consistente na prisão, independente de ordem escrita do juiz competente, de quem é surpreendido cometendo, ou logo após ter cometido um crime ou contravençãa ${ }^{35}$.

A autorização para a prisão cautelar em flagrante sobrevém do seu caráter urgente e em defesa da própria sociedade. Diante a notória ocorrência de um fato criminoso, aguardar a providência de uma autoridade

\footnotetext{
${ }^{34}$ NUCCI, 2014, p. 30.

${ }^{35}$ CAPEZ, Fernando. Curso de Processo Penal. 16 ${ }^{\mathrm{a}}$ ed. Editora Saraiva, 2009. p. 263.
} 
judicial para fundamentar a prisão não seria condizente com a demanda célere que tal situação carece.

Logo, qualquer do povo pode dar voz de prisão a alguém que esteja praticando um fato criminoso. Além disso, ressalta-se o fato de que as autoridades policiais têm o poder-dever de agir de acordo com o Art. 301 CPP e se não agirem com as suas atribuições, poderão responder pelo crime de prevaricação ${ }^{36}$.

Somente há flagrante delito se a conduta do agente estiver tipificada em uma das hipóteses previstas na legislação processual penal, caso o contrário, a prisão será considerada ilegal. O Art. 302 CPP dispõem taxativamente sobre as hipóteses de flagrante ${ }^{37}$.

Denomina-se flagrante próprio/real/autêntico o contexto de flagrância previsto no Art. 302, I e II CPP, que são os casos em que o indivíduo está cometendo ou acaba de cometer a infração penal ${ }^{38}$.

A circunstância elencada no inciso Art. 302, III CPP denomina-se flagrante impróprio/irreal/não autêntico e ocorre quando o indivíduo é perseguido logo após uma situação que faça presumir ser ele o autor da infração ${ }^{39}$.

Quando o agente é encontrado logo depois com instrumentos que façam presumir ser ele o autor da infração, conforme descrito no Art. 302, IV CPP, emerge o denominado flagrante presumido ou suposto ${ }^{40}$.

\footnotetext{
${ }^{36}$ Art. 301 CPP. Qualquer do povo poderá e as autoridades policiais e seus agentes deverão prender quem quer que seja encontrado em flagrante delito.

${ }^{37}$ Art. 302. Considera-se em flagrante delito quem:

I - está cometendo a infração penal;

II - acaba de cometê-la;

III - é perseguido, logo após, pela autoridade, pelo ofendido ou por qualquer pessoa, em situação que faça presumir ser autor da infração;

IV - é encontrado, logo depois, com instrumentos, armas, objetos ou papéis que façam presumir ser ele autor da infração.

${ }^{38}$ NUCCI, 2014, p. 73.

${ }^{39}$ Ibid., p. 73.

${ }^{40}$ Ibid., p. 73.
} 
As expressões logo após e logo depois previstas no Art. 302, III e IV CPP são objetos de controvérsias doutrinárias. As expressões carregam um conteúdo premente conforme o próprio instituto da situação em flagrante dispõe. Vislumbra-se um cenário de perseguição contínua, sem perda do rastro ou desconhecimento da autoria.

Nucci disciplina as duas situações de flagrância da seguinte forma:

(...) ilustrando, no caso do inciso III, a autoridade policial chega ao local do delito alguns minutos após o seu cometimento, recebendo a informação do local para onde se dirigiu o agente, já identificando por testemunhas. Encontra-o, uma ou duas horas depois nesse lugar, dando-lhe voz de prisão em flagrante. No tocante ao inciso IV, a polícia atende a ocorrência de imediato e passa a circular com a vítima pelo bairro a procura do agente do roubo. Minutos após o suspeito se encontrado, ainda carregando consigo a bolsa pertencente a ofendida. Recebe, então voz de prisão ${ }^{41}$.

Todas as situações ensejam a prisão em flagrante do agente, sem ordem judicial, por qualquer cidadão ou por agentes policias. No caso de crimes permanentes, conforme disciplina o Art. 303 CPP, pela consumação perdurar por no tempo, o status de flagrância é estendido enquanto não cessar a permanência ${ }^{42}$.

Há ainda quatro espécies de flagrantes elencadas pela maior parte da doutrina: preparado, esperado, forjado e deferido/retardado.

O flagrante preparado é ocasionado por obra do agente provocador e não é compatível com o ordenamento jurídico.

De acordo com Paulo Rangel:

No flagrante preparado o agente é induzido à ação criminosa pelo chamado "agente provocador" (policial) que faz nascer e alimenta o delito, o qual não seria praticado sem a sua intervenção. A súmula 145 STF diz: "Não há crime quando a preparação do flagrante pela polícia torna impossível a sua consumação". A explicação para a edição desta se dá, pois um Estado Democrático não dar o aval

\footnotetext{
${ }^{41}$ Ibid., p. 73.

42 Art. 303. Nas infrações permanentes, entende-se o agente em flagrante delito enquanto não cessar a permanência.
} 
para a realização de procedimentos policiais que não sejam fruto de um exercício de legalidade ${ }^{43}$.

Flagrante esperado, admitido pelo ordenamento jurídico, ocorre quando a autoridade aguarda o agente provocar o ato ilícito.

\section{Segundo Fernando Capes:}

Nesse caso, a atividade do policial ou do terceiro consiste em simples aguardo do momento do cometimento do crime, sem qualquer atitude de induzimento ou instigação. Considerando que nenhuma situação foi artificialmente criada, não há que se falar em fato atípico ou crime impossível. O agente comete o crime e, portanto, poderá ser efetuada a prisão em flagrante ${ }^{44}$.

Já, o flagrante forjado, também chamado de fabricado, ocorre quando policiais de má fé criam provas inexistentes de um crime, o que é severamente reprimido pelo ordenamento jurídico pátrio.

\section{Conforme Paulo Rangel:}

Ocorre quando maus policias realizam busca pessoal em uma determinada pessoa e inventam que a pessoa estava com posse de drogas por exemplo, e para justificar a voz de prisão, implantam determinada quantidade de entorpecentes no bolso ou no carro do indivíduo. Nesta hipótese, evidentemente, não há crime por parte do indivíduo e somente dos agentes policias ${ }^{45}$.

O flagrante deferido/retardado, titulado também ação controlada, está previsto na Lei 12.850/2013 denominada Lei de Crime Organizado, e tratase de um procedimento policial que possui como objetivo observar e acompanhar determinada ação ilícita com o escopo de efetuar a prisão em um momento oportuno e eficiente, obtendo provas e informações sobre a organização criminosa.

Conforme leciona Paulo Rangel a respeito do tema:

\footnotetext{
${ }^{43}$ RANGEL, 2003, p. 605.

${ }^{44}$ CAPEZ, 2009, p. 263.

${ }^{45}$ RANGEL, 2003, p. 606.
} 
Há, desta forma, uma brecha legal para que os policias possam acompanhar e observar a empreitada criminosa praticada por determinada organização criminosa sem realizar a efetiva prisão em flagrante logo de início e que isso configure o crime de prevaricação por parte e dos agentes ${ }^{46}$.

Pelo fato da prisão em flagrante poder ser efetuada sem a análise do Poder Judiciário, torna-se relevante a sua formalização. Para que a prisão em flagrante esteja em consonância com a legislação é necessário a observância do Art. 302 CPP e que todos os requisitos previstos no Art. 304 CPP tenham sido cumpridos ${ }^{47}$.

A ordem de inquirição prevista neste artigo não pode ser afastada ou alterada. Caso essas formalidades não sejam apreciadas, a prisão será considerada ilegal.

O código, em seu Art. 306 CPP, preceitua algumas formalidades previstas na qualidade de direito fundamental na Constituição como a comunicação imediata da prisão aos familiares do preso e ao juiz. Determina que o Ministério Público também deve ser comunicado e institui o prazo de 24 horas, após a prisão, para que o auto de prisão em flagrante seja encaminhado para o magistrado e para a Defensoria Pública ${ }^{48}$.

\footnotetext{
${ }^{46}$ Ibid., p. 607.

${ }^{47}$ Art. 304. Apresentado o preso à autoridade competente, ouvirá esta o condutor e colherá, desde logo, sua assinatura, entregando a este, cópia do termo e recibo de entrega do preso. Em seguida, procederá à oitiva das testemunhas que o acompanharem e ao interrogatório do acusado sobre a imputação que lhe é feita, colhendo, após cada oitiva suas respectivas assinaturas, lavrando, a autoridade, afinal, o auto.

$\S 1$ o Resultando das respostas fundada a suspeita contra o conduzido, a autoridade mandará recolhê-lo à prisão, exceto no caso de livrar-se solto ou de prestar fiança, e prosseguirá nos atos do inquérito ou processo, se para isso for competente; se não o for, enviará os autos à autoridade que o seja.

§ 20 A falta de testemunhas da infração não impedirá o auto de prisão em flagrante; mas, nesse caso, com o condutor, deverão assiná-lo pelo menos duas pessoas que hajam testemunhado a apresentação do preso à autoridade.

§ 3o Quando o acusado se recusar a assinar, não souber ou não puder fazê-lo, o auto de prisão em flagrante será assinado por duas testemunhas, que tenham ouvido sua leitura na presença deste.

$\S 4$ o Da lavratura do auto de prisão em flagrante deverá constar a informação sobre a existência de filhos, respectivas idades e se possuem alguma deficiência e o nome e o contato de eventual responsável pelos cuidados dos filhos, indicado pela pessoa presa.

48 Art. 306. A prisão de qualquer pessoa e o local onde se encontre serão comunicados imediatamente ao juiz competente, ao Ministério Público e à família do preso ou à pessoa por ele indicada.
} 
Essas formalidades possuem caráter essencial e devem ser concretizadas conforme dita a lei sob pena de tornar a prisão ilegal devendo, então, ser relaxada pelo Poder Judiciário.

O legislador ao disciplinar este artigo visou ratificar a fiscalização do Poder Judiciário uma vez foi concedida a autoridade policial o poder de verificar a priori a presença do fumus boni iuris. A comunicação rápida ao juiz de direito permite que a pessoa fique recolhida por um curto período de tempo cabendo ao magistrado exerce o controle da legalidade do flagrante $\mathrm{e}$ deliberar acerca da medida cabível ao caso concreto.

O Art. $310 \mathrm{CPP}$ estabelece que o juiz, ao ser comunicado da prisão por meio do APF, deve (a) relaxar a prisão dotada de ilegalidade e em seguida verificar se, presentes os requisitos, é cabível a aplicação de (b) medidas cautelares ou da prisão preventiva e a possibilidade da concessão da (c) liberdade provisória ${ }^{49}$.

\section{Segundo Canotilho:}

O princípio da máxima efetividade é um princípio operativo em relação a todas e quaisquer normas constitucionais, e embora sua origem esteja ligada a tese da atualidade das normas programáticas, é hoje sobretudo invocado no âmbito dos direitos fundamentais (no caso deve preferir-se a interpretação que reconheça maior eficácia aos direitos fundamentais $)^{50}$.

\section{A Lei Maior brasileira consagra que no Estado Democrático de} Direito o direito à liberdade é a regra. Assim, de modo a garantir a máxima efetividade da Constituição Federal, o magistrado ao avaliar o APF deve

$\S 1^{\circ}$ Em até 24 (vinte e quatro) horas após a realização da prisão, será encaminhado ao juiz competente o auto de prisão em flagrante e, caso o autuado não informe o nome de seu advogado, cópia integral para a Defensoria Pública.

$\S 2^{\circ}$ No mesmo prazo, será entregue ao preso, mediante recibo, a nota de culpa, assinada pela autoridade, com o motivo da prisão, o nome do condutor e os das testemunhas.

${ }^{49}$ Art. 310. Ao receber o auto de prisão em flagrante, o juiz deverá fundamentadamente:

I - relaxar a prisão ilegal; ou

II - converter a prisão em flagrante em preventiva, quando presentes os requisitos constantes do Art. 312 deste Código, e se revelarem inadequadas ou insuficientes as medidas cautelares diversas da prisão; ou

III - conceder liberdade provisória, com ou sem fiança.

${ }^{50}$ CANOTILHO, J.J.G. Direito constitucional e teoria da Constituição. $6^{\text {a }}$ ed. 1993. p. 227. 
considerar primeiramente a possibilidade da concessão da sua liberdade provisória e, somente se esta não for possível, considerar a aplicação de alguma medida acautelatória, sendo a prisão a última destas.

\subsubsection{Prisão preventiva}

Prevista nos artigos 311 a $316 \mathrm{CPP}$, a prisão preventiva é a modalidade clássica da prisão cautelar sendo a mais rigorosa e mais conhecida de todas as medidas cautelares.

Conforme conceitua Fernando Capes acerca desse instituto jurídico:

Trata-se de uma prisão cautelar de natureza processual decretada pelo juiz durante o inquérito policial ou processo criminal, aténs do trânsito em julgado, sempre que estiverem preenchidos os requisitos legais e ocorrem motivos autorizadores $^{51}$.

Sua decretação deve advir somente de decisão judicial. O juiz somente pode decreta-la de ofício durante o processo. Durante o inquérito, somente pode determinar a prisão preventiva mediante requerimento do Ministério Público ou por representação da autoridade policial. O Art. 311 CPP é, portanto, um legado do sistema processual penal acusatório o qual institui a separação das funções com o escopo de garantir a imparcialidade do juiz ${ }^{52}$.

No Art. 312 CPP estão previstos os dois pressupostos de toda a prisão cautelar: fumus boni iuris e periculum in mora. A fumaça do bom direito é evidenciada na segunda parte do dispositivo quando a lei exige a prova da existência do crime e indício suficiente da autoria do crime.

A lei exige também a demonstração do perigo na demora jurisdicional de modo que a liberdade do acusado represente uma ameaça

\footnotetext{
${ }^{51}$ CAPEZ, 2009, p. 278.

52 Art. 311: Em qualquer fase da investigação policial ou do processo penal, caberá a prisão preventiva decretada pelo juiz, de ofício, se no curso da ação penal, ou a requerimento do Ministério Público, do querelante ou do assistente, ou por representação da autoridade policial.
} 
para a garantia da ordem pública, ordem econômica, conveniência da instrução criminal e para a aplicação da lei penal ${ }^{53}$.

No que tange a expressão "garantia da ordem pública" prevista no código, Paulo Rangel leciona:

Por ordem pública a paz e a tranquilidade social que deve existir no seio da comunidade, com todas as pessoas vivendo em perfeita harmonia, sem que haja qualquer comportamento divorciado do modus vivendi em sociedade. Assim, se o indiciado ou o acusado em liberdade continuar a praticar ilícitos penais no curso do processo, a medida extrema é necessária se presentes os demais requisitos dos indícios da autoria e prova da existência do crime ${ }^{54}$.

Em suma, a garantia da ordem pública envolve a própria segurança pública. Entretanto, faz-se necessário conferir a este instituto um significado concreto quando aplicado na prática. A interpretação conservadora, que se baseia em presunções abstratas de qualquer infração, utiliza a garantia da ordem pública como uma "carta coringa" para justificar a decretação da prisão preventiva de qualquer delito que atente contra o ordenamento jurídico. É necessário que se prevaleça sempre o caráter excepcional e emergencial da prisão cautelar.

No que se refere a decretação da prisão preventiva para assegurar a aplicação da lei penal, disciplina o jurista Nucci que "vincula-se precipuamente, a potencial fuga do agente, evitando qualquer eficiência punitiva estatal. Não se trata de presunção de fuga" ${ }^{55}$.

A prisão para atestar a aplicação da lei penal normalmente é um meio de se evitar a fuga do indiciado ou do acusado. Geralmente deve ser aplicada quando o agente começa a dar indícios de que pretende fugir nos

\footnotetext{
${ }^{53}$ Art. 312. A prisão preventiva poderá ser decretada como garantia da ordem pública, da ordem econômica, por conveniência da instrução criminal, ou para assegurar a aplicação da lei penal, quando houver prova da existência do crime e indício suficiente de autoria.

Parágrafo único. A prisão preventiva também poderá ser decretada em caso de descumprimento de qualquer das obrigações impostas por força de outras medidas cautelares (Art. 282, § 40).

${ }^{54}$ RANGEL, 2003, p. 616.

${ }^{55}$ NUCCI, 2014, p. 96.
} 
casos em que, por exemplo, vende todo o seu patrimônio, compra passagens aéreas e renova o passaporte.

O judiciário precisa atentar para que a fuga não seja considerada uma presunção judicial. Não é o poder econômico do réu ou a existência de um passaporte de outra nacionalidade que automaticamente fará o juiz presumir que o mesmo irá evadir-se para evitar uma possível sansão penal. Devem existir, além do fumu boni iuris (indícios de autoria e prova da existência do crime) reais indicativos da pretensão de fuga do agente.

No que se refere a decretação da prisão preventiva por garantia da instrução criminal, Antonio Scaranse Fernandes comenta:

A prisão por conveniência da instrução criminal serve para garantir a prova. São exemplos dessa hipótese a prisão porque há ameaça a testemunha ou porque pode o acusado eliminar provas importantes ${ }^{56}$.

A custódia por adequação da instrução criminal é conveniente quando há indícios de que o agente está ameaçando testemunhas, manipulando provas, subornando peritos e autoridades com o escopo de prejudicar ou até impedir que se chegue a verdade real dos fatos.

Abordando o prisma da garantia da ordem econômica, Nucci acrescenta:

Noutros termos, a ordem econômica, quando abalada, tende a acarretar gravame a ordem pública. Reserva-se tal prisma a delinquência de colarinho branco, crimes financeiros e tributários. Quem comete um crime desse porte, insistindo, enquanto aguarda a investigação ou processo, a permanecer ativo em seus negócios fraudulentos e ilícitos, certamente, provoca abalo a ordem econômica, justificando a decretação da prisão cautelar ${ }^{57}$.

O magistrado pode decretar a prisão preventiva para evitar que o agente continue praticando delitos contra a ordem econômica. Esta hipótese

\footnotetext{
${ }^{56}$ FERNANDES, 1999, p. 302.
}

${ }^{57}$ NUCCI, 2014, p. 96. 
foi considerada como um requisito para a prisão preventiva em razão do crescimento da criminalidade econômica e financeira nas últimas décadas.

Importante frisar que se não estiverem presentes os referidos elementos do fumus boni iuris (no que se refere a indícios suficientes de autoria e prova da existência do crime) e o periculum in mora (caso em que a concessão da liberdade ocasionaria uma ameaça latente à ordem pública, ordem econômica, conveniência da instrução criminal, e aplicação da lei penal) fundamentados por uma decisão judicial, ninguém poderá ser mantido no cárcere.

A prisão preventiva somente é admitida nos crimes praticados com dolo e com pena privativa de liberdade máxima que transpassa 4 anos conforme Art. 313 CPP. Pode ser imposta como sanção ao agente que injustificadamente descumpriu uma obrigação imposta por alguma medida cautelar $^{58}$.

Assim como a prisão preventiva pode ser decretada em qualquer fase processual ou da instrução criminal desde que subsistam os requisitos, a prisão poderá ser revogada quando os motivos que embasaram a decisão não mais existirem, conforme disciplina o Art. $316 \mathrm{CPP}^{59}$.

No que se diz respeito ao instituto da prisão cautelar, Paulo Rangel sabiamente faz um alerta para a sociedade:

(...) não podemos confundir prisão cautelar com política pública seria de combate à violência, ou seja, nada tem a ver com a prisão cautelar os altos índices de violência urbana que assolam nosso País. (...) deve o Estado adotar medidas necessária para conter essa onda de violência e não culparmos o judiciário que não lançou mão de uma medida cautelar para conte-la. Uma coisa é a certeza que há polícia outra é haver necessidade de, no curso do processo, o réu ser preso.

O Art. 319 CPP elenca várias medidas cautelares diversas da prisão que restringem a liberdade do indivíduo que podem, inclusive, serem

\footnotetext{
${ }^{58}$ NUCCI, 2014, p. 99.

${ }^{59}$ Ibid., p. 102.
} 
aplicadas cumulativamente. Em muitos casos as medidas cautelares são perfeitamente cabíveis e eficientes, sem a necessidade de automática segregação. Somente se, após a avaliação do caso concreto, vislumbrar-se que as medidas são insuficientes é que deve-se aplicar a prisão preventiva como ultima ratio.

\subsubsection{Medidas cautelares diversas da prisão}

O código de processo penal, alterado pela Lei 12.403/11, lista um rol de medidas cautelares distintas da prisão. Tratam-se de medidas que, dependendo do caso concreto, se demonstram suficientes para atingir o principal escopo de manter o agente, que responde a um processo criminal, sob controle e vigilância sem que seja necessário o seu encarceramento.

O princípio da supremacia da Constituição $0^{60}$ atrelado ao princípio da máxima efetividade ${ }^{61}$ norteiam que as leis infraconstitucionais sejam interpretadas a luz da Constituição Federal, exigindo-se uma interpretação que reconheça uma maior eficácia dos direitos fundamentais, em especial, o direito à liberdade.

Dito isso a liberdade, então, é a regra geral e a prisão do indivíduo, a excepcionalidade. Motivo pelo o qual a prisão preventiva cautelar somente pode ser imposta como ultima ratio ou seja, somente quando as outras medidas cautelares alternativas ao cárcere se demonstrarem ineficientes e inadequadas para obstarem uma possível situação de perigo ocasionada pelo status libertatis do agente.

O legislador conferiu uma proteção a esse instituto ao disciplinar no Art. $282 \S 4^{\circ}$ CPP que quando descumprida a medida imposta pelo

\footnotetext{
${ }^{60}$ É a lei suprema do Estado, pois é nela que se encontram a própria estruturação destes e a organização de seus órgãos; é nela que se acham as normais fundamentais de Estado, e só nisso se notará sua superioridade em relação as demais normas jurídicas. LENZA, 2008, p. 117.

${ }^{61} \mathrm{O}$ princípio da máxima efetividade das normas constitucionais deve ser entendido no sentido de a norma constitucional ter a mais ampla efetividade social. Ibid., p. 73.
} 
magistrado, é possível a conversão da medida cautelar em prisão preventiva $^{62}$.

As medidas cautelares devem ser norteadas e impostas de acordo com a adequação e a necessidade do caso concreto ${ }^{63}$.

Tais medidas poderão ser aplicadas isoladas ou cumulativamente. Podem ser revogadas, substituídas e decretadas novamente pelo magistrado se sobrevierem razões que as justifiquem segundo o Art. $282, \S 1^{\circ}$ e $\S 5^{\circ}$ $\mathrm{CPP}^{64}$.

\section{Conforme leciona Nucci:}

A medida cautelar é um instrumento restritivo de liberdade, de caráter provisório e urgente, diverso da prisão, como forma de controle e acompanhamento do acusado, durante a persecução penal, desde que necessária e adequada ao caso concreto. Estão previstas no Art. $319 \mathrm{CPP}^{65}$.

As medidas cautelares estão elencadas no Art. $319^{66}$ e Art. $320^{67}$ CPP.

\footnotetext{
${ }^{62}$ Art. $282 \S^{\circ}$ - No caso de descumprimento de qualquer das obrigações impostas, o juiz, de ofício ou mediante requerimento do Ministério Público, de seu assistente ou do querelante, poderá substituir a medida, impor outra em cumulação, ou, em último caso, decretar a prisão preventiva (Art. 312, parágrafo único).

${ }^{63}$ Art. 228 CPP - As medidas cautelares previstas neste Título deverão ser aplicadas observando-se a:

I - necessidade para aplicação da lei penal, para a investigação ou a instrução criminal e, nos casos expressamente previstos, para evitar a prática de infrações penais;

II - adequação da medida à gravidade do crime, circunstâncias do fato e condições pessoais do indiciado ou acusado.

${ }^{64}$ Art. $282 \S 1^{\circ} \mathrm{CPP}$ - As medidas cautelares poderão ser aplicadas isolada ou cumulativamente. Art. $282 \S 5^{\circ} \mathrm{CPP}$ - juiz poderá revogar a medida cautelar ou substituí-la quando verificar a falta de motivo para que subsista, bem como voltar a decretá-la, se sobrevierem razões que a justifiquem. ${ }^{65}$ NUCCI, 2014, p. 30.

${ }^{66}$ Art. 319: São medidas cautelares diversas da prisão:

I - comparecimento periódico em juízo, no prazo e nas condições fixadas pelo juiz, para informar e justificar atividades;

II - proibição de acesso ou frequência a determinados lugares quando, por circunstâncias relacionadas ao fato, deva o indiciado ou acusado permanecer distante desses locais para evitar o risco de novas infrações;

III - proibição de manter contato com pessoa determinada quando, por circunstâncias relacionadas ao fato, deva o indiciado ou acusado dela permanecer distante;

IV - proibição de ausentar-se da Comarca quando a permanência seja conveniente ou necessária para a investigação ou instrução;
} 
A medida cautelar prevista no inciso I do Art. 319 CPP, visa assegurar o poder de vigilância e controle do Estado com o agente, uma vez que estipula o comparecimento periódico em juízo. Caso o réu não se apresente ou não cumpra as condições fixadas pelo juiz, poderá ser preso preventivamente.

A imposição da medida mencionada no inciso II do Art. 319 CPP, evita que o agente cometa novas infrações associadas ao fato, a priori, praticado. $\mathrm{O}$ agente pode ser proibido de frequentar lugares onde se consume bebidas alcoólicas, boates e estádios de futebol por exemplo.

O inciso III do Art. 319 CPP prevê uma medida específica para as situações em que possível autor e vítima se conheçam. O Estado impõe que o agente mantenha distancia da vítima para evitar novos conflitos relacionados ao fato oriundo de um processo ou uma investigação criminal.

A medida cautelar prevista no inciso IV do Art. 319 CPP que proíbe o indivíduo de se afastar da Comarca, ilustra a necessidade, quando conveniente, do poder de vigilância e controle do Estado com relação ao indivíduo. Na prática, esta medida é geralmente utilizada cumulativamente a outra.

O inciso V do Art. 319 CPP prevê uma medida fundada nos preceitos da prisão domiciliar. O Estado almeja que o indiciado ou acusado se distancie do meio social, mais especificamente no período noturno, nos

$\mathrm{V}$ - recolhimento domiciliar no período noturno e nos dias de folga quando o investigado ou acusado tenha residência e trabalho fixos;

VI - suspensão do exercício de função pública ou de atividade de natureza econômica ou financeira quando houver justo receio de sua utilização para a prática de infrações penais

VII - internação provisória do acusado nas hipóteses de crimes praticados com violência ou grave ameaça, quando os peritos concluírem ser inimputável ou semi-imputável (Art. 26 do Código Penal) e houver risco de reiteração;

VIII - fiança, nas infrações que a admitem, para assegurar o comparecimento a atos do processo, evitar a obstrução do seu andamento ou em caso de resistência injustificada à ordem judicial;

IX - monitoração eletrônica.

$\S 4$ o A fiança será aplicada de acordo com as disposições do Capítulo VI deste Título, podendo ser cumulada com outras medidas cautelares.

67 Art. 320: A proibição de ausentar-se do País será comunicada pelo juiz às autoridades encarregadas de fiscalizar as saídas do território nacional, intimando-se o indiciado ou acusado para entregar o passaporte, no prazo de 24 (vinte e quatro) horas. 
fins de semana e nos dias de folga sob pena da conversão da medida cautelar em prisão preventiva quando descumpridas tais condições.

A previsão do inciso VI do Art. 319 CPP se destina a uma medida geralmente utilizada nos delitos contra a administração pública, como a corrupção por exemplo, e contra o sistema econômico e financeiro.

A medida cautelar disciplinada no inciso VII do Art. 319 CPP de internação deve ser realizada em locais apropriados diversos do cárcere comum uma vez que é inverossímil manter um indivíduo com sinais nítidos de enfermidade em uma prisão comum.

O instituto da fiança como medida cautelar prevista no inciso VIII do Art. 319 CPP, visa estabelecer o pagamento de determinada quantia em dinheiro de modo a persuadir o indivíduo a estar presente nos atos processuais, a cumprir as ordens judiciais sob pena de perda econômica. Normalmente esta medida é imposta a indivíduos com grande poder aquisitivo e aplicadas cumulativamente a outras.

A monitoração eletrônica como medida cautelar do inciso IX do Art. 319 CPP, possibilita o controle, a vigilância e a fiscalização do réu durante o processo ou o inquérito.

A proibição de se ausentar do país, medida cautelar disposta no Art. 320 CPP, consiste na entregar do passaporte no prazo de 24 horas após a sua intimação.

Em síntese, as medidas cautelares diversas ao cárcere protegem os bens jurídicos tutelados relacionadas a um fato sem necessidade de se determinar a privação severa de um direito tão fundamental como a liberdade do acusado através da prisão.

\subsubsection{Prisão temporária}


A prisão temporária está prevista na Lei 7960/89, é uma espécie de prisão cautelar que exige para a sua configuração os requisitos de todas as medidas cautelares: fumus boni iuris e o periculum in mora.

Vislumbra-se o fumus boni iuris no Art. $1^{\circ}$, III da Lei 7960/89 quando o artigo exige, para a prisão, fundadas razões de autoria ou participação do indiciado nos crimes próprios previstos na lei. Já, o periculum in mora, está presente no inciso I e II do mesmo artigo ${ }^{68}$.

Conforme leciona o jurista Fernando Capez acerca do conceito de prisão temporária: "Trata-se de uma prisão cautelar de natureza processual destinada a possibilitar as investigações a respeito de crimes graves, durante o inquérito policial”69.

Em razão da má redação ao Art. $1^{\circ}$ Lei 7960/89, este dispositivo pode causar dúvidas quanto a interpretação cumulativa ou alternativa dos requisitos. $\mathrm{O}$ entendimento que prevalece é o de que a prisão temporária pode ser efetuada nos crimes apontados no inciso III se presentes as condições do inciso I ou do inciso II.

\footnotetext{
${ }^{68}$ Art. $1^{\circ}$ - Caberá prisão temporária:

I - quando imprescindível para as investigações do inquérito policial;

II - quando o indicado não tiver residência fixa ou não fornecer elementos necessários ao esclarecimento de sua identidade;

III - quando houver fundadas razões, de acordo com qualquer prova admitida na legislação penal, de autoria ou participação do indiciado nos seguintes crimes:

a) homicídio doloso (Art. 121, caput, e seu $\S 2^{\circ}$ );

b) sequestro ou cárcere privado (Art. 148, caput, e seus $\S \S 1^{\circ} \mathrm{e} 2^{\circ}$ );

c) roubo (Art. 157, caput, e seus $\S \S 1^{\circ}, 2^{\circ}$ e $3^{\circ}$ );

d) extorsão (Art. 158, caput, e seus $\S \S 1^{\circ}$ e $2^{\circ}$ );

e) extorsão mediante sequestro (Art. 159 , caput, e seus $\S \S 1^{\circ}, 2^{\circ}$ e $3^{\circ}$ )

f) estupro (Art. 213, caput, e sua combinação com o Art. 223, caput, e parágrafo único);

g) atentado violento ao pudor (Art. 214, caput, e sua combinação com o Art. 223, caput, e parágrafo único);

h) rapto violento (Art.219, e sua combinação com o Art. 223 caput, e parágrafo único);

i) epidemia com resultado de morte (Art. 267, $\S 1^{\circ}$ );

j) envenenamento de água potável ou substância alimentícia ou medicinal qualificado pela morte (Art. 270, caput, combinado com Art. 285);

1) quadrilha ou bando (Art. 288), todos do Código Penal;

m) genocídio (Arts. $1^{\circ}, 2^{\circ}$ e $3^{\circ}$ da Lei $n^{\circ} 2.889$, de $1^{\circ}$ de outubro de 1956), em qualquer de suas formas típicas;

n) tráfico de drogas

o) crimes contra o sistema financeiro

p) crimes previstos na Lei de Terrorismo.

${ }^{69}$ CAPEZ, 2009, p. 283.
} 
Conforme leciona Damasio de Jesus a respeito do tema:

É imprescindível que se trate de um dos crimes referidos no inciso III. O rol é taxativo e não pode ser ampliado. Não é necessário, entretanto, que as condições dos três incisos coexistam ${ }^{70}$.

Na mesma linha de interpretação, elucida o jurista Nucci:

(...) somente se pode decretar a temporária nas hipóteses descritas pelo inciso III associadas a imprescindibilidade paras as investigações do inquérito policial, ou quando o indiciado não tiver residência fixa ou não fornecer elementos necessários ao esclarecimento da sua identidade ${ }^{71}$.

A gravidade abstrata do crime, por si só, não é elemento suficiente para que a prisão temporária seja determinada. Ressalta-se que a custódia cautelar não é uma satisfação à sociedade em um Estado Democrático de Direito onde contempla-se o princípio da presunção de inocência. O magistrado somente poderá determina-la se o suposto crime estiver previsto no rol taxativo da lei, ser a prisão uma medida imprescindível para a investigação ou ser demonstrado que o suspeito não tem residência fixa ou identidade certa.

$\mathrm{O}$ Art. $2^{\circ}$ da Lei que regula a prisão temporária institui que esta somente pode ser decretada pelo magistrado desde que em face de representação da autoridade policial ou a requerimento do Ministério Público e durante as investigações do inquérito. Este inciso consagra o fundamento do sistema processual acusatório quando garante a imparcialidade do juiz durante a fase policial, uma vez que é defeso ao magistrado de ofício decretar a prisão temporária, somente podendo institui-la quando provocado por outro órgão e mediante decisão fundamentada, respeitando os requisitos traçados pela lei.

\footnotetext{
${ }^{70}$ JESUS, Damásio E. de. Código de Processo Penal Anotado. $9^{\mathrm{a}}$ ed. v. tb. RT, 1995. p. 643.

${ }^{71}$ NUCCI, 2014, p. 62.
} 
O Art. $2^{\circ}$ prevê que o prazo máximo para a prisão temporária é de 5 dias prorrogável em uma única vez, por igual período, nos casos de fundada necessidade ${ }^{72}$.

Nos casos dos crimes hediondos o Art. $2^{\circ}$, $\S^{\circ}$ Lei 8.072/90 prevê que o prazo máximo da prisão temporária será de 30 dias prorrogáveis na mesma forma ${ }^{73}$.

\section{Segundo o jurista Nucci:}

A prisão temporária é uma das modalidades de prisão cautelar de cunho persecutório penal, decretada na fase da investigação criminal, com o objetivo de aprimora-la, tornando-a eficiente, dentro dos parâmetros constitucionais ${ }^{74}$.

Muitas são as críticas apontas pela doutrina no tocante a forma como a prisão temporária foi formalmente regulamentada no ordenamento jurídico brasileiro.

A prisão temporária foi instituída pela Medida Provisória 111/89 e posteriormente convertida na Lei 7960/89. Muito se discute a respeito da constitucionalidade da prisão temporária uma vez que esta foi criada pelo Poder Executivo e não pelo Poder Legislativo.

\footnotetext{
${ }^{72}$ Art. $2^{\circ}$ A prisão temporária será decretada pelo Juiz, em face da representação da autoridade policial ou de requerimento do Ministério Público, e terá o prazo de 5 (cinco) dias, prorrogável por igual período em caso de extrema e comprovada necessidade.

$\S 1^{\circ} \mathrm{Na}$ hipótese de representação da autoridade policial, o Juiz, antes de decidir, ouvirá o Ministério Público.

$\S 2^{\circ} \mathrm{O}$ despacho que decretar a prisão temporária deverá ser fundamentado e prolatado dentro do prazo de 24 (vinte e quatro) horas, contadas a partir do recebimento da representação ou do requerimento.

$\S 3^{\circ}$ O Juiz poderá, de ofício, ou a requerimento do Ministério Público e do Advogado, determinar que o preso lhe seja apresentado, solicitar informações e esclarecimentos da autoridade policial e submetê-lo a exame de corpo de delito.

$\S 4^{\circ}$ Decretada a prisão temporária, expedir-se-á mandado de prisão, em duas vias, uma das quais será entregue ao indiciado e servirá como nota de culpa.

$\S 5^{\circ}$ A prisão somente poderá ser executada depois da expedição de mandado judicial.

$\S 6^{\circ}$ Efetuada a prisão, a autoridade policial informará o preso dos direitos previstos no Art. $5^{\circ} \mathrm{da}$ Constituição Federal.

$\S 7^{\circ}$ Decorrido o prazo de cinco dias de detenção, o preso deverá ser posto imediatamente em liberdade, salvo se já tiver sido decretada sua prisão preventiva.

${ }^{73}$ Art. $2^{\circ} \S 4^{\circ}$ - A prisão temporária, sobre a qual dispõe a Lei no 7.960 , de 21 de dezembro de 1989, nos crimes previstos neste artigo, terá o prazo de 30 (trinta) dias, prorrogável por igual período em caso de extrema e comprovada necessidade.
}

${ }^{74}$ NUCCI, 2014, p. 61. 
O jurista Paulo Rangel se manifesta acerca da problemática afirmando:

(...) a prisão foi criada através da Medida Provisória $n^{\circ} 111$ de 24 de novembro de 1989, ou seja, o Executivo, através da Medida Provisória, legislou sobre o Processo Penal e Direito Penal, matérias que são de competência privativa da União e, portanto, deveriam ser tratadas pelo Congresso Nacional (...). Neste caso, entendemos que a Lei traz um vício de iniciativa que não é sanado com a conversão da medida em lei. Há flagrante inconstitucionalidade por vício formal, qual seja: a iniciativa da matéria ${ }^{75}$.

Alguns doutrinadores afirmam que a prisão temporária é uma ofensa ao Estado Democrático de Direito e inconstitucional. A crítica é feita pois o Estado, diante a inexistência de elementos suficientes que comprovem o delito se vale da constrição da liberdade do indivíduo para que esses elementos sejam de fato alcançados. O Estado primeiro prende e depois investiga.

Paulo Rangel é adepto desta linha doutrinaria ao afirmar que:

(...) o Estado prende, por sua incompetência, para investigar se o indiciado é ou não autor do fato. Faz-nos lembrar a famigerada prisão para averiguação da época da ditadura, através do instituto da contravenção de vadiagem, ondo o indivíduo era preso por vadiagem, para que se pudesse investigar um outro delito em que havia suspeita de sua autoria e/ou participação ${ }^{76}$.

Nucci por usa vez, defende o caráter constitucional da lei:

(...) a prisão temporária destina-se muitas vezes, a permitir a colheita de provas da materialidade da infração penal e dos elementos básicos de autoria. Eis por que se trata de um mal necessário. Embora de curta duração, nem sempre decretada em função de motivos sólios, pelo menos se trata de medida cautelar privativa de liberdade controlada pelo judiciário ${ }^{77}$.

\subsubsection{Prisão domiciliar como medida cautelar}

\footnotetext{
${ }^{75}$ RANGEL, 2003, p. 643.

${ }^{76}$ RANGEL, 2003, p. 644.

${ }^{77}$ NUCCI, 2014, p. 63.
} 
A prisão domiciliar é o recolhimento do indivíduo em sua moradia, somente podendo ausentar-se com autorização judicial. Pode ser aplicada na forma preventiva (como medida cautelar, regulada pelo código de processo penal) ou durante a execução de uma pena restritiva de liberdade (regulada pela lei de execução penal).

Como já tratado anteriormente, a prisão cautelar difere-se da prisão pena pois a primeira é decretada para acautelar o processo e a segunda, é a pena privativa de liberdade decorrente de sentença penal condenatória transitada em julgado.

A prisão domiciliar como medida cautelar decretada antes da condenação definitiva, que consiste no recolhimento do indiciado ou acusado em sua residência, substitui a prisão preventiva quando o agente cumpre um dos requisitos do Art. $318 \mathrm{CPP}^{78}$.

A respeito das hipóteses de cabimento da prisão domiciliar cautelar como substituta da prisão preventiva, destacam-se as alterações que a recente Lei 13.257/16 trouxe para o instituto.

A antiga redação do inciso IV do Art. 418 CPP previa que somente as gestantes a partir do $7^{\circ}$ mês de gravidez, ou sendo esta de alto risco, teriam direito à prisão domiciliar. A nova lei com viés protetivo aos direitos humanos, estabeleceu que basta a indiciada ou acusada estar grávida para cumprir o requisito. Além disso, a lei inovou ao estabelecer que a mulher com filho de até 12 (doze) anos de idade incompletos ou o homem, caso

\footnotetext{
${ }^{78}$ Art. 318 Poderá o juiz substituir a prisão preventiva pela domiciliar quando o agente for:

I - maior de 80 (oitenta) anos;

II - extremamente debilitado por motivo de doença grave;

III - imprescindível aos cuidados especiais de pessoa menor de 6 (seis) anos de idade ou com deficiência;

IV - gestante; (Redação dada pela Lei n ${ }^{\circ} 13.257$, de 2016)

V - mulher com filho de até 12 (doze) anos de idade incompletos; (Incluído pela Lei no 13.257, de 2016)

VI - homem, caso seja o único responsável pelos cuidados do filho de até 12 (doze) anos de idade incompletos. (Incluído pela Lei no 13.257, de 2016)

Parágrafo único. Para a substituição, o juiz exigirá prova idônea dos requisitos estabelecidos neste artigo.
} 
seja o único responsável pelos cuidados do filho de até 12 (doze) anos de idade incompletos, fazem jus ao instituto desde de que devidamente comprovados os requisitos.

\subsubsection{Prisão como execução provisória de sentença condenatória confirmada em segunda instância}

A prisão como execução provisória de sentença penal condenatória apesar de não ser uma modalidade de prisão cautelar, é um tema recente e merece uma rápida menção no presente trabalho.

O STF revolucionou a interpretação jurisprudencial ao permitir a execução da pena antes do trânsito em julgado.

O HC 126.292, que deu origem a discussão, foi impetrado com o intuito de contrapor uma decisão prolatada pelo TJ/SP que determinou o início da execução da pena antes do seu trânsito em julgado. Por maioria de 7 votos contra 4, o plenário do STF negou provimento ao $\mathrm{HC}$ inovando a jurisprudência da Corte. Prevalece, a partir de agora, o entendimento de que depois da sentença condenatória confirmada em segunda instancia, já é possível exigir-se a execução da pena sem a necessidade de se esperar o trânsito em julgado, ou seja, antes de se esgotar todas as instâncias recursais cabíveis da decisão.

Como argumentos sustentados a favor da execução da sentença penal condenatória antes de consumado o seu trânsito em julgado, temos o fato de que nos recursos extraordinários e nos recursos especiais não cabe mais a discussão de matéria fática probatória e sim, somente, a questão de direito. Assim, após a segunda instância, haveria o trânsito em julgado das questões fundadas em provas e fatos do processo, possibilitando, portanto, uma antecipação de pena. 
Segundos os dizeres do Ministro Relator Teori Zavascki em seu voto:

(...) É dizer: os recursos de natureza extraordinárias não configuram desdobramentos do duplo grau de jurisdição, porquanto não são recursos de ampla resolutividade, já que não se prestam ao debate da matéria fática probatória. Noutras palavras, com o julgamento implementado pelo Tribunal de apelação, ocorre espécie de preclusão da matéria envolvendo os fatos da causa. Os recursos ainda cabíveis para instancias extraordinárias do STJ e do STF recurso especial e extraordinário - têm, como se sabe, âmbito de cognição estrito a matéria de direito. Nessas circunstancias, tendo havido, em segundo grau, um juízo de incriminação do acusado, fundado em fatos e provas insuscetíveis de reexame pela instancia extraordinária, parece inteiramente justiçável a relativização e até mesmo a própria inversão para o caso concreto, do princípio da presunção de inocência até então observado ${ }^{79}$.

Outro argumento endossado pela maioria dos ministros do STF neste julgamento, diz respeito ao efeito meramente devolutivo dos recursos especiais e extraordinários. Por estes recursos não serem dotados de efeito suspensivo, segundo o Art. $27 \S 2^{\circ}$ Lei $8038 / 90^{80}$, nada impedem a prisão decorrente de acordão que, em apelação, confirmou a sentença penal condenatória (ainda recorrível).

\section{Conforme ilustra Ministro Edson Fachin em seu voto que} acompanhou o voto do relator:

Se afirmarmos que a presunção de inocência não cede nem mesmo depois de um juízo monocrático ter afirmado a culpa de um acusado, com a subsequente confirmação por parte de experientes julgadores de segundo grau, soberanos na avaliação dos fatos e integrantes de instancia a qual não se opõem limites a devolutividade recursal, reflexamente estaríamos a afirmar que a Constituição erigiu uma presunção absoluta de desconfianças as decisões provenientes das instancias ordinárias ${ }^{81}$.

O direito comparado também foi utilizado como argumento favorável ao entendimento de que a decisão de segunda instância já é suficiente para o cumprimento antecipado de pena. O ministro Teori

\footnotetext{
${ }^{79}$ STF, HC n. 126.292/SP. Rel. Ministro Teori Zavascki, Brasília, 17 fev. 2016.

${ }^{80}$ Art. 27 - Recebida a petição pela Secretaria do Tribunal e aí protocolada, será intimado o recorrido, abrindo-se-lhe vista pelo prazo de quinze dias para apresentar contrarrazões: $\S 2^{\circ}$ - Os recursos extraordinário e especial serão recebidos no efeito devolutivo.

${ }^{81}$ STF, HC n. 126.292/SP. Rel. Ministro Teori Zavascki, Brasília, 17 fev. 2016.
} 
Zavascki ilustra seu voto mencionando que o direito inglês, norteamericano, canadense, alemão, francês, português, espanhol e argentino admitem o cumprimento de pena, mesmo pendentes outros recursos. No cenário internacional observa-se que depois da segunda instância, a execução de uma condenação não fica suspensa aguardando o julgamento dos recursos pela Corte Suprema.

Além disso, foi utilizado o argumento de que a interposição dos recursos especiais e extraordinários, na maioria dos casos, é tida como estratégia de defesa para protelar a pretensão punitiva ou executória do Estado.

Conforme ilustra o voto do Ministro Luiz Roberto Barroso que também acompanhou o relator:

Além disso, a execução provisória da pena permitirá reduzir o grau de seletividade do sistema punitivo brasileiro. Atualmente, como já demonstrado, permite-se que as pessoas com mais recursos financeiros, mesmo que condenadas, não cumpra a pena ou possam procrastinar a sua execução por mais 20 anos. Como é intuitivo, as pessoas que hoje superlotam as prisões brasileiras (muitas vezes, sem qualquer condenação de primeiro ou segundo grau) não tem condições de manter advogado para interpor um recurso atrás do outro. (...) A alteração da compreensão do STF acerca do momento de início de cumprimento da pena (...) produzirá um efeito republicano e igualitário sobre o sistema ${ }^{82}$.

A contrário sensu, os votos vencidos alegam que a execução antecipada da sentença penal condenatória antes do trânsito em julgado propaga um retrocesso do Estado Democrático de Direito não compatível com o sistema constitucional vigente.

O argumento primordial dos Ministros que tiveram seus votos vencidos no referido julgamento, e de maior parte da doutrina, é que a execução provisória de sentença penal condenatória é uma violação do princípio constitucional da presunção de inocência.

${ }^{82}$ Ibid., 17 fev. 2016. 
Pelo princípio da presunção de inocência previsto no Art. $5^{\circ}, \mathrm{LVII}$ da Constituição, entende-se que toda pessoa se presume inocente até que tenha sido declarada culpada por sentença transitada em julgado.

O Pacto de San José da Costa Rica no seu Art. $8^{\circ} \S^{\circ}$, recepcionado pelo Brasil via decreto $678 / 92$, preceitua a respeito deste princípio $^{83}$.

Claramente observa-se que o trânsito em julgado da sentença penal condenatória foi o marco legal escolhido pelo legislador constituinte para estabelecer o fim da presunção de inocência do réu. Ou seja, o réu somente será considerado culpado quando não se puder mais recorrer da decisão condenatória, seja porque já foram esgotadas todas as instâncias recursais, o prazo para recorrer se exauriu ou por decisão própria do réu de não querer recorrer da decisão.

Adverso a decisão final do STF, o Ministro Celso de Mello em seu voto no julgamento do HC 126.912, critica o instituto da execução provisória da sentença penal condenatória pois esta seria uma ofensa ao princípio da presunção de inocência:

Acho importante acentuar que a presunção de inocência não se esvazia progressivamente, a medida em que se sucedem os graus de jurisdição. Isso significa, portanto, que, mesmo confirmada a condenação penal por um Tribunal de segunda instancia, ainda assim subsistirá, em favor do sentenciado esse direito fundamental, que só deixará de prevalecer - repita-se - com o trânsito em julgado da sentença penal condenatória, como claramente estabelece, em texto inequívoco, a Constituição da República ${ }^{84}$.

O Ministro Marco Aurélio, preocupado com as consequências que a execução provisória da sentença penal condenatória ainda recorrível as instancias extraordinárias, alerta:

\footnotetext{
${ }^{83}$ Art. $8^{\circ}, \S 2^{\circ}$ - "Toda pessoa acusada de delito tem direito a que se presuma sua inocência enquanto não se comprove legalmente sua culpa. Durante o processo, toda pessoa tem direito, em plena igualdade, às seguintes garantias mínimas: (...).

Enquanto a Constituição institui o princípio da seguinte forma:

Art. $5^{\circ}$, LVII - ninguém será considerado culpado até o trânsito em julgado de sentença penal condenatória;

${ }^{84}$ STF, HC n. 126.292/SP. Rel. Ministro Teori Zavascki, Brasília, 17 fev. 2016.
} 
Indaga-se: perdida a liberdade, vindo o título condenatório e provisório - porque ainda sujeito a modificação por meio de recurso - a ser alterado, transmudando-se condenação em absolvição, a liberdade será devolvida ao cidadão? Aquele que surge como inocente? A resposta, Presidente, é negativa ${ }^{85}$.

Ressalta-se ainda que o postulado da presunção de inocência tem previsão no Art. $5^{\circ}$, LVII ${ }^{86}$ da Constituição Federal, Art. $8^{\circ} \S 2^{\circ}$ do Pacto de San Jose da Costa Rica ${ }^{87}$ e no Código de Processo Penal no Art. 283 CPP $^{88}$.

Outros documentos internacionais como por exemplo a Declaração Universal de Direitos da Pessoa Humana, a Declaração Americana dos Direitos e Deveres do Homem, a Convenção Europeia para Salvaguardar os Direitos do Homem e das Liberdades Fundamentais entre outros, também proclamam que todos presumem-se inocentes até a condenação judicial definitiva.

Como já mencionado anteriormente estamos inseridos em uma cultura de prisão compulsória na qual o cerceamento da liberdade do indivíduo é visto pelos magistrados, com o apoio da sociedade, como a primeira medida cabível, muitas das vezes a única, e eficiente a ser tomada.

Essa prática possui reflexos diretos com o quadro caótico do sistema carcerário atual, sua falta de estrutura e a sua superlotação. O STF ao decidir favoravelmente a execução provisória da sentença penal antes de transitada em julgado, além de violar preceitos constitucionais contribuiu ainda mais para a deterioração do sistema carcerário atual.

É bem verdade que o Brasil, nos dias atuais, vem passando por uma crise política evidente, ilustrada por escândalos de corrupção e imoralidade

\footnotetext{
${ }^{85}$ Ibid., 17 fev. 2016.

${ }^{86}$ Art. $5^{\circ}$, LVII CF - ninguém será considerado culpado até o trânsito em julgado de sentença penal condenatória.

${ }^{87} \operatorname{Art} .8^{\circ}, \S 2^{\circ}$ - Toda pessoa acusada de delito tem direito a que se presuma sua inocência enquanto não se comprove legalmente sua culpa. Durante o processo, toda pessoa tem direito, em plena igualdade, às seguintes garantias mínimas: (...).

${ }^{88}$ Art. 283 CPP - Ninguém poderá ser preso senão em flagrante delito ou por ordem escrita e fundamentada da autoridade judiciária competente, em decorrência de sentença condenatória transitada em julgado ou, no curso da investigação ou do processo, em virtude de prisão temporária ou prisão preventiva.
} 
por parte dos nossos representantes políticos. Entretanto, os Ministros do STF não podem valer-se de seus cargos para inovar interpretações incompatíveis com os padrões democráticos estabelecidos pela Constituição, com o propósito de dar uma resposta ao clamo social. Permitir a relativização do preceito fundamental da presunção de inocência, significa abrir a possibilidade para que outros direitos e garantias constitucionais, que conferem dignidade ao indivíduo, possam ser flexibilizados no futuro ameaçando assim, a existência de um Estado Democrático de Direito.

É necessário observar que a prisão como execução provisória da pena antes do seu trânsito em julgado não é a única solução para legitimar a prisão do réu enquanto o mesmo recorre da decisão. A prisão cautelar, quando presentes os requisitos, admite o encarceramento do réu enquanto perdurar o processo, sem contradizer os padrões democráticos constitucionalizados.

Por fim, é de suma importância relatar que diante manifesta violação do princípio constitucional que gerou controversas na jurisprudência, a OAB ajuizou no STF uma Ação Declaratória de Constitucionalidade (ADC $\left.\mathrm{n}^{\mathrm{o}} 44\right)$ visando atestar o caráter constitucional do Art. $283 \mathrm{CPP}^{89}$, não mencionado no julgamento do $\mathrm{HC}$ em questão. O Partido Ecológico Nacional também ingressou com uma Ação Direta de Constitucionalidade (ADC $\mathrm{n}^{\circ}$ 43) que versa, também, a respeito do reconhecimento da legitimidade do Art. 283 CPP.

As ADC 44 e 43 foram julgadas no dia 05/10/2016. Por 6 a 5, os Ministros mantiveram o entendimento proferido em fevereiro no julgamento do HC 12692 de que o réu que tiver a sua sentença condenatória confirmada por um Tribunal de Justiça ou por um Tribunal de Justiça

\footnotetext{
${ }^{89}$ Art. 283 CPP - Ninguém poderá ser preso senão em flagrante delito ou por ordem escrita e fundamentada da autoridade judiciária competente, em decorrência de sentença condenatória transitada em julgado ou, no curso da investigação ou do processo, em virtude de prisão temporária ou prisão preventiva.
} 
Regional Federal, já poderá comprimir a pena ainda que subsistam recursos pendentes no STJ e STF.

Por ser um instituto novo, acredita-se que muito tem-se a discutir a respeito do mesmo na prática e na doutrina no que tange a sua constitucionalidade e a sua aplicabilidade. 


\section{CAPÍTULO 2 - A CULTURA DO ENCARCERAMENTO EM MASSA, PRISÃO CAUTELAR E A REALIDADE CARCERÁRIA BRASILEIRA}

Retomando aos estudos evidenciados no capítulo anterior, vivemos em um Estado Democrático de Direito que adota o sistema processual acusatório regrado pelo princípio do devido processo legal que garante o estrito cumprimento de todos os imperativos previstos na Constituição durante o trâmite do processo. Vigora como regra, portanto, a liberdade de ir e vir do indivíduo e, como exceção, o cerceamento deste direito na forma da prisão.

É necessário que os magistrados interpretem o código de processo penal de modo a garantir a máxima efetividade dos direitos fundamentais constitucionais. A liberdade é a regra no nosso Estado Democrático de Direito devendo a prisão, principalmente a de natureza cautelar, ser vista como uma contingência excepcional. Não podem os magistrados permitir que suas decisões judiciais sejam influenciadas pelo clamor social e midiático.

\section{Conforme elucida Décio Alonso Gomes:}

O debate social e político sobre a justiça tem como plano de fundo uma percepção generalizada de crise do sistema judicial no seu conjunto e, especificamente, do plano penal. Esta percepção tem sido dramatizada pela crescente visibilidade social dos tribunais nos meios de comunicação em massa. A aproximação da sociedade (...) da maior visibilidade do trabalho realizado pelo Judiciário pelos agentes de persecução, não se faz acompanhar da necessária transparência e acessibilidade, o que tende a aumentar a percepção ou concepção, de um sistema ineficaz, inoperante, permeável e manipulável, com evidentes déficits de democracia ${ }^{90}$.

A desmoralização social quanto a política pública de combate a violência vem sendo, erroneamente, associada ao direito penal produzindo

\footnotetext{
${ }^{90}$ GOMES, Décio Alonso. (Des)Acelaração Processual: Abordagens sobre dromologia na busca do tempo razoável do Processo Penal. Rio de Janeiro: Editora Lumen Juris, 2007. p. 2-3.
} 
consequências diretas no Poder Judiciário. Em razão disso, os direitos fundamentais processuais do réu vêm sendo relativizados principalmente com relação ao princípio da presunção de inocência e o uso abusivo das prisões cautelares durante o processo. Não se pode confundir prisão cautelar com política pública. Os autos indicieis de violência nada tem a ver com a atuação do Poder Judiciário e sim com a ineficiência do Poder Executivo.

Neste capítulo teceremos a relação entre a cultura do encarceramento em massa, o desvio de finalidade da prisão cautelar, mais especificamente a prisão preventiva, e a hiperlotação do sistema penitenciário brasileiro.

\subsection{O desvio de finalidade do instituto da prisão cautelar}

A prisão cautelar, em um Estado Democrático de Direito, não pode ser encarada como uma satisfação que o Poder Judiciário "deve" à sociedade. Por mais grave que seja o suposto crime cometido, a prisão preventiva, por exemplo, tem como finalidade exclusiva assegurar o curso do processo de modo a possibilitar que a prestação jurisdicional seja ministrada de forma adequada e somente pode ser decretada quando presentes seus requisitos.

Conforme elucida o jurista Paulo Rangel:

O Judiciário não pode substituir a ação do Executivo. Polícia nas ruas, garantindo segurança, é problema do Executivo. Prisão cautelar, para assegurar o processo penal justo, é medida a ser adotada pelo Poder Judiciário (...) uma coisa é a certeza de que nas ruas não há polícia, outra, bem diferente é em decorrência disso, haver necessidade de, no curso do processo, o réu ser preso ${ }^{91}$.

Vive-se em uma sociedade inserida na cultura do encarceramento que associa, equivocadamente, a solução para os autos índices de violência urbana ao Direito Penal e as prisões. O clamo midiático e social volta-se para intensificar o rigor punitivista estatal. O Poder Legislativo cria mais

\footnotetext{
${ }^{91}$ RANGEL, 2003, p. 581.
} 
tipos penais e elevavam as penas dos crimes. O Poder Judiciário, por sua vez, impõe regimes mais gravosos aos condenados, sem amparo legal, e "banalizam" o instituto da prisão preventiva.

Segundo dados $^{92}$ fornecidos pelo Levantamento Nacional de Informação Penitenciaria - Infopen 2014, o Brasil alcançou o quarto lugar no ranking dos países com a maior quantidade de pessoas recolhidas ao cárcere e quase a metade destas, são presos provisórios.

Este quadro evidencia na prática, portanto, que o Poder Judiciário possui uma grande parcela de responsabilidade no cenário de superlotação do sistema penitenciário.

Tal situação gera custos sociais, políticos e econômicos proeminentes e potencializa a criminalidade. O Poder Judiciário ao "banalizar" o instituto da prisão preventiva, coloca em prática a cultura do encarceramento e contribui para a superlotação do sistema carcerário, gerando um ciclo vicioso entre a violação de direitos mínimos fundamentais dos presos, o aumento da criminalidade e da insegurança social. Analisemos: a superlotação é a raiz dos demais problemas do sistema carcerário. Quanto mais pessoas são encarceradas, agravam-se as condições degradantes e sub-humanas a que os presos são submetidos. Sob custódia, os presos são sujeitados à condições precárias de salubridade em suas celas, proliferação de doenças, rebeliões, escassez de agua potável, falta de alimentação mínima de qualidade, produtos de higiene básicos, mortes e violências sexuais. Os cárceres não alcançam o fim de ressocialização dos presos sendo incontestável que os detidos submetidos a este tratamento indigno, saem do presidio propensos a cometerem mais crimes. Pesquisas ${ }^{93}$

\footnotetext{
${ }^{92}$ INFOPEN, Levantamento Nacional de Informações Penitenciária. jun. 2014. Disponível em: $<$ https://www.justica.gov.br/noticias/mj-divulgara-novo-relatorio-do-infopen-nesta-tercafeira/relatorio-depen-versao-web.pdf>. Acesso em: 15 ago. 2016.

${ }^{93}$ IPEA, Instituto de Pesquisa Econômica Aplicada. Relatório de Pesquisa: Reincidência no Brasil. 2015. Disponível em: <http://www.cnj.jus.br/files/conteudo/destaques/arquivo/2015/07/572bba385357003379ffeb4c9aa 1f0d9.pdf $>$. Acesso em: 24 ago. 2016.
} 
demonstram que um a cada quatro ex-condenados, volta a ser condenado por algum crime no prazo de cinco anos sendo que, a maioria são ex-presos provisórios que passaram a integrar alguma facção criminosa a partir do contato com outros custodiados nos presídios. As altas taxas de reincidência, causam mais insegurança a população que, por sua vez, pleiteia por mais enceramentos. O Poder Judiciário, para corresponder ao clamo social e midiático, consolida a cultura do encarceramento em massa, agravando ainda mais o quadro crítico da superlotação do sistema carcerário.

Além de ser a liberdade um dos principais direitos fundamentais característico de um real Estado Democrático de Direito devendo ser cerceado somente em situações de extrema necessidade, inserir um indivíduo desnecessariamente no sistema carcerário como medida cautelar, significa que estar-se-á contribuindo, ainda mais, para a saturação das prisões e para violações generalizadas de seus direitos como pessoa humana prejudicando, assim, toda a sociedade.

Embora exista uma fronteira relevante entre a legitima necessidade de assegurar a ordem pública, ordem econômica, instrução criminal, aplicação da lei penal e o impulso punitivo estatal, a arbitrariedade do Estado, nutrida pela cultura do encarceramento, contribui para o aprisionamento em massa que vem ocorrendo no Brasil.

Como já previa Cesare Beccaria em 1764:

(...) a razão está em que o sistema atual da jurisprudência criminal apresenta os nossos espíritos a ideia da forca e do poder, em vez da justiça; é que se atiram, na mesma masmorra, sem distinção alguma o inocente suspeito e o criminoso convicto; é que a prisão, entre nós, é antes de tudo um suplício e não um meio de deter um acusado; é que, enfim, as forças que estão externamente em defesa do trono e dos direitos da nação estão separadas daquelas que mantem as leis no interior, quando deveriam estar intimamente ligadas ${ }^{94}$.

\footnotetext{
${ }^{94}$ BECCARIA, 2013, p. 24-25.
} 
Somado a todo o exposto, apesar da liberdade ser a regra em um Estado Democrático de Direito por força do princípio da presunção de inocência, da decretação da prisão preventiva ser autorizada restritivamente quando presentes os requisitos do Art. 312 CPP e somente quando as outras medidas cautelares diversas do cárcere se demonstrarem insuficientes ao caso concreto, os juízes vinculam a prisão como a primeira (única) ratio das medidas cautelares e protagonista do sistema processual penal brasileiro.

Conforme elucida Aury Lopes Jr. e Caio Paiva em seu artigo a respeito da temática abordada:

O (con)texto da prisão, no Brasil, é tão preocupante que sequer se registrou uma mudança efetiva na prática judicial após o advento da Lei 12.403/2011, (dita) responsável por colocar, no plano legislativo, a prisão como a ultima ratio das medidas cautelares (...). E o que verificamos na prática? Simples: que a lógica judicial permanece vinculada ao protagonismo da prisão, que a homologação do flagrante, longe de ser a exceção, figura como regra no sistema processual penal brasileiro. Prova disso é que não houve a tão esperada redução do número de presos cautelares após a reforma de $2011^{95}$.

\subsection{Realidade carcerária brasileira}

De acordo com os dados ${ }^{96}$ fornecidos pelo Levantamento Nacional de Informação Penitenciaria - Infopen 2014, o total de pessoas privadas de liberdade no Brasil em junho de 2014 era correspondente a 607.731 para quase 377 mil vagas do sistema penitenciário. Além disso, demonstram que $41 \%$ dos aprisionados eram provisórias, isso significa dizer que quatro a cada dez presos encarcerados não tinham sido julgados e condenados.

Além disso os dados catalogados demonstram que a taxa de aprisionamento no Brasil, que ocupa a indecorosa posição de $4^{\circ}$ lugar dos países com mais pessoas presas no mundo, tende a crescimento contínuo. Enquanto os outros países, Estados Unidos ( $1^{\circ}$ lugar no ranking), a China

\footnotetext{
${ }^{95}$ LOPES, Aury Jr.; PAIVA, Caio. Audiência de Custódia e a imediata apresentação do preso ao juiz: Rumo à evolução civilizatória do processo penal. Disponível em: <http://www.revistaliberdades.org.br/site/outrasEdicoes/outrasEdicoesExibir.php?rcon_id=209>. Acesso em: 25 ago. 2016.

${ }^{96}$ INFOPEN, Levantamento Nacional de Informações Penitenciária. Acesso em: 15 ago. 2016.
} 
( $2^{\circ}$ lugar no ranking) e a Rússia ( $3^{\circ}$ lugar no ranking), estão reduzindo seu ritmo de encarceramento, o Brasil presenciou o aumento de $33 \%$ da sua taxa de aprisionamento entre dos anos de 2008 a 2014.

Segundo as palavras de Edmundo Campos Coelho que ilustram, com veracidade, o sistema penitenciário:

\begin{abstract}
Surdas, úmidas e imundas, escuras e sufocantes nas quais se isola o preso por longos períodos e inspetores e guardas que o agridem e humilham na calada da noite não são, efetivamente, apenas imagens literárias. Não são ficção, e é absolutamente necessário proteger o preso da violência oficial. (...) Outro é o caso, todavia, da proteção do preso contra o preso, do fraco contra o forte, agressivo e violento. Como garantir a integridade física - e frequentemente a vida - do preso fraco e indefeso que habita celas coletivas onde amontam- se de trinta a quarenta outros presos, alguns já brutalizados pela vida no cárcere, mas todos carentes das mais básicas condições de existência digna ${ }^{97}$ ?
\end{abstract}

Para reverter o quadro crescente de aumento da população carcerária e todas as consequências advindas das problemáticas apontadas anteriormente, principalmente no que se refere as prisões provisórias, bastaria, portanto, que os magistrados não fechassem os olhos para a realidade do estado de falência do sistema carcerário e cumprissem o disposto na lei processual penal.

Uma das soluções encontradas para remodelar este cenário é a implementação da Audiência de Custódia. Trata-se de um instituto que além de ser um direito do preso, busca com a humanização da relação juizpreso romper com os paradigmas endossados pelo Poder Judiciário (grande maioria) que possui consequenciais direitas nos altos índices de decretação de prisão preventiva diante a análise do APF.

A comunicação da prisão em flagrante ao juiz através do APF não é eficiente para que o magistrado disponha de subsídios concisos para analisar as condições pessoais do detido, impondo medidas alternativas diversa ao cárcere de ordem pessoal por exemplo, e ainda relaxar as prisões

\footnotetext{
97 COELHO, Edmundo Campos. A Oficina do Diabo: Crise e conflitos no sistema penitenciário do Rio de Janeiro. Rio de Janeiro: Editora Espaço e Tempo LTDA; IUPERJ, 1987. p. 14.
} 
viciadas de ilegalidade. Assim, diante uma demanda diária e crescente de APF somada a cultura do encarceramento no qual a sociedade em seu tudo está inserida, a prisão preventiva passa a ser a primeira medida a ser considerada pelo magistrado, mesmo nos casos em que o detido cumpra os requisitos para responder ao processo criminal em liberdade.

A Audiência de Custódia, portanto, além de ser um direito do preso demonstra ser uma solução democrática para o declínio da barreira arquiteta pela cultura do encarceramento e delimitada pelo auto de prisão em flagrante.

No próximo capítulo, serão apontados estudos sobre a Audiência de Custódia abordando os principais temas relacionados ao instituto e uma reflexão crítica acerca dos seus aspectos mais relevantes. 


\section{CAPÍTULO 3 - AUDIÊNCIA DE CUSTÓdIA E AS SUAS DIRETRIZES NOS TRATADOS INTERNACIONAIS}

A Convenção Americana sobre Direitos Humanos, identificada também como Pacto de San José da Costa Rica, foi ratificada pelo Brasil através do Decreto Lei nº 678 de 1992.

Este tratado se embasa na Declaração Universal dos Direitos Humanos e prevê imperativos normativos que se respaldam nos direitos fundamentais da pessoa humana, na justiça social e na liberdade. Os países que se afiliam ao Pacto se comprometem a reafirmar os direitos políticos, culturais, civis e a integralidade física e psíquica inerente a pessoa humana.

A Corte Interamericana de Direitos Humanos, criada pelo Pacto de San José da Costa Rica, é um órgão judicial cujo fito primordial é a interpretação dos artigos mencionados no Pacto e a salvaguarda da efetivação de seus regramentos.

Ao reconhecer a jurisdição da Corte Interamericana de Direitos Humanos por meio de uma declaração expressa ${ }^{98}$, sendo esta uma faculdade dos Estados signatários do Pacto, o Brasil se subordina também a precedentes, jurisprudência, e a interpretação das normas ali previstas, emanadas pelo órgão.

O Art. $7^{\circ}$ item 5 do Pacto de San José da Costa Rica dispõem:

Art. $7^{\circ}$ - Direito à liberdade pessoal

5. Toda pessoa presa, detida ou retida deve ser conduzida, sem demora, à presença de um juiz ou outra autoridade autorizada por lei a exercer funções judiciais e tem o direito de ser julgada em prazo razoável ou de ser posta em

\footnotetext{
98 Art. 62 - 1. Todo Estado-parte pode, no momento do depósito do seu instrumento de ratificação desta Convenção ou de adesão a ela, ou em qualquer momento posterior, declarar que reconhece como obrigatória, de pleno direito e sem convenção especial, a competência da Corte em todos os casos relativos à interpretação ou aplicação desta Convenção.
} 
liberdade, sem prejuízo de que prossiga o processo. Sua liberdade pode ser condicionada a garantias que assegurem o seu comparecimento em juízo.

A Corte Interamericana de Direitos Humanos, consolida o entendimento de que o simples conhecimento do juiz sobre a prisão de um indivíduo, através de um documento (APF), não é tão eficiente quanto a apresentação física do preso ao juiz. O contato pessoal entre detido em flagrante e magistrado, propicia uma deliberação mais eficaz a respeito da manutenção do cárcere, da concessão da liberdade, da análise sobre o caráter legal da prisão e da fiscalização de eventuais maus-tratos sofridos pelos detidos em sede policial.

Consoante o veredito da Corte Interamericana de Direitos Humanos no caso Acosta Calderón Vs. Ecuador:

Como tem sido apontado em outros casos, o Tribunal considera certos esclarecimentos (...).Primeiro, os termos da garantia estabelecida no artigo 7.5 da Convenção são claros em que a pessoa detida deve ser levada imediatamente a um juiz ou a autoridade judicial competente, de acordo com os princípios de controle judicial e rapidez processual. Isto é essencial para a proteção do direito à liberdade pessoal e conceder proteção a outros direitos como a vida e a integridade pessoal. $\mathrm{O}$ mero conhecimento por um juiz de que uma pessoa é detida não satisfaz esta garantia, o detido deve comparecer pessoalmente e dar sua declaração ao juiz ou autoridade competente ${ }^{99}$.

A evidência da imperatividade dos preceitos instituidos pelo Pacto de San José da Costa Rica em cenario nacional deu-se diante o julgamento do RE 466.343 pelo STF. Neste julgamento ${ }^{100}$, foi conferido a particuladidade de norma supralegal ao referido Pacto.

\footnotetext{
${ }^{99}$ Tal y como lo ha señalado en otros casos, este Tribunal estima necesario realizar algunas precisiones sobre este punto64. En primer lugar, los términos de la garantía establecida en el artículo 7.5 de la Convención son claros en cuanto a que la persona detenida debe ser llevada sin demora ante un juez o autoridad judicial competente, conforme a los principios de control judicial e inmediación procesal. Esto es esencial para la protección del derecho a la libertad personal y para otorgar protección a otros derechos, como la vida y la integridad personal. El simple conocimiento por parte de un juez de que una persona está detenida no satisface esa garantía, ya que el detenido debe comparecer personalmente y rendir su declaración ante el juez o autoridad competente. Caso Acosta Calderón Vs. Ecuador. p. 26. Disponível em: <http://www.corteidh.or.cr/docs/casos/articulos/seriec_129_esp1.pdf〉. Acesso em: 16 ago.2016. 100 (...) antes da entrada em vigor da Emenda 45/2004, os tratados internacionais de direitos humanos, anteriormente a sua ratificação pelo Presidente da República, eram exclusivamente
} 


\author{
Segundo conclui o Ministro Gilmar Mendes em seu voto que \\ solidificou o posicionamento do STF quanto ao status de norma supralegal \\ do Pacto em analise:
}

\begin{abstract}
Em conclusão, entedo que, desde a adesão do Brasil sem qualquer reserva, ao Pacto Internacional dos Direitos Civis e Políticos (...) e à Convenção Americana sobre Direitos Humanos - Pacto de San José da Costa Rica (...), ambos em 1992 (...) o carater especial desses diplomas internacionais sobre direitos humanos lhes reserva lugar especifico no ordenamento juridico, estando abaixo da Constituição, porém acima da legislação interna. $\mathrm{O}$ status normativo supralegal dos tratados internacionais de direitos humanos subscritos pelo Brasil, dessa forma, torna inaplicavel a legislação infraconstitucional com ele conflitante, seja ela anterior ou posterios ao ato de adesão ${ }^{101}$.
\end{abstract}

\author{
Além de ter base legal no Pacto de San José da Costa Rica, a questão \\ da breve condução do preso a autoridade competente após a prisão também \\ está prevista no Art. 9, item 3 do Pacto Internacional dos Direitos Civis e \\ Políticos, ratificado pelo Brasil através Decreto Lei no 592/1992.
}

\begin{abstract}
Art. $9^{\circ}$
3. Qualquer pessoa presa ou encarcerada em virtude de infração penal deverá ser conduzida, sem demora, à presença do juiz ou de outra autoridade habilitada por lei a exercer funções judiciais e terá o direito de ser julgada em prazo razoável ou de ser posta em liberdade. A prisão preventiva de pessoas que aguardam julgamento não deverá constituir a regra geral, mas a soltura poderá estar condicionada a garantias que assegurem o comparecimento da pessoa em questão à audiência, a todos os atos do processo e, se necessário for, para a execução da sentença.
\end{abstract}

\footnotetext{
aprovados (por meio de Decreto Legislativo) por maioria simples, nos termos do Art. 49, I, CF, o que gerava inúmeras controvérsias jurisprudenciais sobre a aparente hierarquia infraconstitucional (nível de normas ordinárias) desses instrumentos internacionais no nosso Direito interno. (...) A Emenda Constitucional $n^{\circ} 45$ (...) estabeleceu, no $\S^{\circ}$ do art. $5^{\circ}$ da Carta de 1988 , que os tratados e convenções internacionais sobre direitos humanos serão equivalentes às emendas constitucionais, uma vez aprovados, em cada Casa do Congresso Nacional, em dois turnos, por três quintos dos votos dos seus representantes. (...). Surgiria, ainda, o problema em saber se os tratados de direitos humanos ratificados Internacional sobre Direitos Civis e Políticos e tantos outros, poderiam ter o status de norma constitucional (...). Não há no citado qualquer menção ou ressalva dos compromissos assumidos anteriormente pelo Brasil. (...) o STF passou a atribuir aos tratados de direitos humanos (quando não aprovados pelo sistema do art. $5^{\circ} \S 3^{\circ}$ da Constituição) o nível de norma supralegal (a partir de 3 de novembro de 2008, com o julgamento do RE 466.343-1 SP). MAZZUOLI, Valerio de Oliveira. Curso de Direito Internacional Público. $4^{\mathrm{a}}$ ed. Editora Revista dos Tribunais, 2010. p. 767-771.

${ }^{101}$ STF, RE 466.343-1/SP, Rel. Ministro Gilmar Mendes, Brasília, 31 dez. 2008.
} 
Diante de todo o exposto, (a)apesar de décadas da incorporação do Pacto de San José da Costa Rica e do Pacto Internacional dos Direitos Civis e Políticos no ordenamento jurídico pátrio, (b)do reconhecimento do status normativo supralegal desses tratados internacionais e (c)da submissão jurisprudencial do Brasil à Corte Interamericana de Direitos Humanos, o comando da obrigatoriedade da apresentação, sem demora, do detido ao juiz competente, não é uma realidade na pratica forense de todo o Brasil.

A Audiência de Custódia é, portanto, o nome concedido pela doutrina nacional ao instituto que corresponde a pronta apresentação do preso ao magistrado, após ter o seu direito de liberdade cerceado. Trata-se de um direito da pessoa presa e permite que o juiz, através do contato pessoal com detido, possa obter mais informações e subsídios para deliberar acerca da legalidade da prisão, da necessidade da manutenção do encarceramento, ou da possibilidade da concessão da liberdade provisória. Além disso, a apresentação pessoal do preso ao juiz, permite que o Poder Judiciário realize um controle mais rígido sobre os atos de violência e maus-tratos praticados contra os aprisionados em sede policial.

Neste capítulo, desenvolveremos a temática acerca da morosidade e das dificuldades da disseminação do instituto da Audiência de Custódia por todo o território nacional, do seu conceito, das suas peculiaridades, da relação entre este instituto e o cenário internacional e da importância da sua implementação como solução para reverter o quadro caótico do sistema carcerário brasileiro.

\subsection{Audiência de Custódia e o direito comparado}

Na experiência do Direito Comparado, é válido mencionar que a pronta apresentação do preso a autoridade judiciaria, após o cometimento de um delito, é uma prática consagrada no cenário internacional, não só no contexto da Americana Latina, mas de todo o mundo. 
O Chile, país que assim como o Brasil ratificou ${ }^{102}$ o Pacto de San José da Costa Rica, em seu código de processo penal institui que o preso deve ser apresentado a um promotor no prazo de 12 horas cabendo libertar o detido ou encaminha-lo ao juiz competente, no prazo máximo de 24 horas.

Art. 131. Os prazos de prisão.

(...) Quando a detenção se praticar em virtude dos artigos 129 e 130, o policial que tiver a realizado, ou o gerente do centro de detenção deve informar o Ministério Público no prazo máximo de doze horas. O procurador poderá deixar sem efeito a prisão ou encaminhar o detido a um juiz dentro de um período máximo de vinte e quatro horas, contadas desde quando a prisão tiver sido efetuada. Se o procurador não se manifestar, a polícia deve apresentar o detido perante a autoridade judicial dentro do período especificado (... $)^{103}$.

O código de processo penal da Colombia, país que também afiliou$\operatorname{se}^{104}$ ao Pacto de San José da Costa Rica, prevê a apresentação do preso ao juiz no período de 36 horas.

Art. 297. Para capturar se exigirá ordem escrita que será proferida por um juiz de controle de garantias, formalidades legais e motivo previamente definidos por lei. (...).

Capturada a pessoa será colocada a disposição de um juiz de controle de garantias dentro de um prazo máximo de trinta e seis (36) horas para que efetue a audiência

\footnotetext{
102 Disponível em:

<https://www.cidh.oas.org/basicos/portugues/d.Convencao_Americana_Ratif..htm>. Acesso em: 20 ago.2016.

${ }^{103}$ Artículo 131.- Plazos de la detención. (...) Cuando la detención se practicare en virtud de los artículos 129 y 130, el agente policial que la hubiere realizado o el encargado del recinto de detención deberán informar de ella al ministerio público dentro de un plazo máximo de doce horas. El fiscal podrá dejar sin efecto la detención u ordenar que el detenido seconducido ante el juez dentro de un plazo máximo de veinticuatro horas, contado desde que la detención se hubiere practicado. Si el fiscal nada manifestare, la policía deberá presentar el detenido ante la autoridad judicial en el plazo indicado. (...). Disponível em:

<http://www.leychile.cl/Navegar?idNorma=176595>. Acesso em: 20 ago.2016.

PAIVA, Caio et al.. Audiência de Custódia Comentários à Resolução 213 do Conselho Nacional de Justiça. $1^{\mathrm{a}}$ ed. Porto Alegre: Livraria do Advogado, 2016, p. 67.

${ }^{104}$ Disponível em:

<https://www.cidh.oas.org/basicos/portugues/d.Convencao_Americana_Ratif..htm>. Acesso em: 20 ago. 2016.
} 
de controle de legalidade, ordene o cancelamento do mandado de captura e tome a decisão adequada no que diz respeito ao apreendido ${ }^{105}$.

\title{
A Constituição da Guatemala, país que também aderiu ${ }^{106}$ ao Pacto de
}

\section{San José da Costa Rica, prevê expressamente que o prazo de apresentação do preso ao juiz após o cometimento do delito não pode exceder 6 horas.}

\author{
Art. $6^{\circ}$. Detenção legal.
}

\begin{abstract}
Ninguém pode ser preso ou detido, se não por causa de crime ou contravenção penal e em virtude de uma ordem emitida nos termos da lei por uma autoridade judiciária competente. Excepcionam os casos de flagrante delito (...). Os detidos devem ser colocados à disposição da autoridade judicial competente num prazo não superior a seis horas, e não podem ficar sujeitos a nenhuma outra autoridade.
\end{abstract}

O funcionário ou autoridade que viola as disposições do presente artigo serão punidos de acordo com a lei $(. . .)^{107}$.

\footnotetext{
${ }^{105}$ Artículo 297. Requisitos Generales.

Para la captura se requerirá orden escrita proferida por un juez de control de garantías con las formalidades legales y por motivos razonablemente fundados, de acuerdo con el artículo 221, para inferir que aquel contra quien se pide librarla es autor o partícipe del delito que se investiga, según petición hecha por el respectivo fiscal.

Capturada la persona será puesta a disposición de un juez de control de garantías en el plazo máximo de treinta y seis (36) horas para que efectúe la audiencia de control de legalidad, ordene la cancelación de la orden de captura y disponga lo pertinente con relación al aprehendido.

PARÁGRAFO. Salvo los casos de captura en flagrancia, o de la captura excepcional dispuesta por la Fiscalía General de la Nación, con arreglo a lo establecido en este código, el indiciado, imputado o acusado no podrá ser privado de su libertad ni restringido en ella, sin previa orden emanada del juez de control de garantías.

Disponível em: <https://www.hrw.org/pt/news/2014/02/03/252627>. Acesso em: 22 ago. 2016.

Disponível em:

<http://www.secretariasenado.gov.co/senado/basedoc/ley_0906_2004_pr007.html\#297>. Acesso em: 22 ago. 2016.

PAIVA, 2016, p. 67.

${ }^{106}$ Disponível em:

<https://www.cidh.oas.org/basicos/portugues/d.Convencao_Americana_Ratif..htm>. Acesso em: 22 ago. 2016.

107 Articulo 6.- Detención legal.

Ninguna persona puede ser detenida o presa, sino por causa de delito o falta y en virtud de orden librada con apego a la ley por autoridad judicial competente. Se exceptúan los casos de flagrante delito o falta. Los detenidos deberán ser puestos a disposición de la autoridad judicial competente en un plazo que no exceda de seis horas, y no podrán quedar sujetos a ninguna otra autoridad. El funcionario, o agente de la autoridad que infrinja lo dispuesto en este artículo será sancionado conforme a la ley, y los tribunales, de oficio, iniciarán el proceso correspondiente. Constitución de Guatemala, Art. $6^{o}$. Disponível em:

<https://es.wikisource.org/wiki/Constituci\%C3\%B3n_de_Guatemala>. Acesso em: 22 ago. 2016. PAIVA, 2016, p. 93.
} 
O Constituição de Portugal ${ }^{108}$, por sua vez, prevê que a apresentação do preso ao juiz deve ocorrer em 48 horas após o cometimento do delito.

Art. $28^{\circ}$

1. A detenção será submetida, no prazo máximo de quarenta e oito horas, a apreciação judicial, para restituição à liberdade ou imposição de medida de coação adequada, devendo o juiz conhecer das causas que a determinaram e comunicá-las ao detido, interrogá-lo e dar-lhe oportunidade de defesa.

\section{A Constituição da África do Sul disciplina que a apresentação do} preso a um Tribunal competente deve correr no prazo máximo de 48 horas após a sua prisão.

Art. 35. Presos, detidos e pessoas acusadas.

1. Todo indivíduo preso por ter supostamente cometido um delito tem o direito:

d. de ser conduzido a um tribunal o mais rápido possível, não ultrapassando o limite de

(i) 48 horas após a detenção; ou

(ii) do fim do primeiro dia de expediente forense depois da expiração das 48 horas, se as 48 horas expirarem fora do horário de expediente ou em um dia em que não haja expediente forense ${ }^{109}$;

${ }^{108}$ Artigo $28^{\circ}$

1. A detenção será submetida, no prazo máximo de quarenta e oito horas, a apreciação judicial, para restituição à liberdade ou imposição de medida de coacção adequada, devendo o juiz conhecer das causas que a determinaram e comunicá-las ao detido, interrogá-lo e dar-lhe oportunidade de defesa. Disponível em:

〈http://www.parlamento.pt/Legislacao/Paginas/ConstituicaoRepublicaPortuguesa.aspx>. Acesso em: 22 ago. 2016.

ANDRADE, Mauro Fonseca; ALFLEN, Pablo Rodrigo. Audiência de Custódia no Processo Penal Brasileiro. $2^{\mathrm{a}}$ ed. Porto Alegre: Livraria do Advogado, 2016. p. 67.

109 35. Arrested, detained and accused persons

1 - Everyone who is arrested for allegedly committing an offence has the right -

d. to be brought before a court as soon as reasonably possible, but not later than -

i. 48 hours after the arrest; or

ii. the end of the first court day after the expiry of the 48 hours, if the 48 hours expire outside ordinary court hours or on a day which is not an ordinary court day. Disponível em: <http://www.gov.za/documents/constitution/Constitution-Republic-South-Africa-1996-1>. Acesso em: 22 ago. 2016. 
Os países citados acima, são exemplos de nações que normatizaram em seus ordenamentos jurídicos o direito do preso, o mais breve possível, de ser apresentado a uma autoridade judiciaria competente após a sua prisão, de modo a garantir os seus direitos fundamentais contra eventuais violações por parte do Estado.

\title{
Segundo Mauro Fonseca Andrade e Pablo Rodrigo Alflen:
}

\begin{abstract}
Não tardou muito a que outros diplomas de cunho nacional ratificassem esse imperativo de apresentação das pessoas privadas em sua liberdade ao juiz ou outra autoridade que exercesse poderes judiciais. Na América do Sul, alguns países inseriram a necessidade dessa apresentação do preso em sua própria constituição, ao passo que outros preferiram inseri-la na legislação infraconstitucional. Entretanto, o Brasil vem se mostrando tímido - para não se dizer resistente - em dar plena aplicabilidade a todos os termos das Convenção Americana de Direitos Humanos, da qual ele próprio é signatário. (...) o Brasil é um dos poucos países da América Latina - quiçá, o único - a não contemplar tal direito em sua legislação ${ }^{110}$.
\end{abstract}

Apesar das diretrizes da Audiência de Custódia terem sido recepcionadas pelo ordenamento jurídico nacional há mais de 2 décadas, o Brasil ainda não possui uma lei normatizando a condução do detido, o mais breve possível, a uma autoridade judiciária após a sua prisão.

\subsection{A implementação da Audiência de Custódia no Brasil}

Apesar deste instituto ter base legal em tratados de direitos humanos ratificados pelo Brasil, a apresentação física do preso sem demora a autoridade judiciária após a prisão, não se verificava na pratica forense brasileira. O instituto da Audiência de Custodia se ajusta ao artigo $7^{\circ}$ item 5 do Pacto de San José da Costa Rica, e ao artigo $9^{\circ}$ item 3 do Pacto Internacional de Direitos Civis e Político, como já dito anteriormente. 
$\mathrm{O}$ código de processo penal em seu Art. $306 \S 1^{\circ} \mathrm{CPP}^{111}$ disciplina que em até 24 horas o APF deve ser encaminhado ao juiz, nada versa, porém, sobre o contato físico do preso com o juiz de direito.

Constata-se na prática que a comunicação da prisão em flagrante ao juiz, realizada por meio de um mero documento (auto de prisão em flagrante) demonstra não ser tão eficiente quanto o contato físico entre ambos. A Audiência de Custódia visa a "humanização" do processo penal, mais especificamente da relação entre juiz-preso. Com uma apresentação pessoal, o juiz pode colher mais informações e obter subsídios para deliberar de forma mais concisa a respeito da manutenção da prisão ou a concessão da liberdade provisória. É um direito do preso. Além disso, o controle de eventuais maus tratados em sede policial pelo Poder Judiciário também é mais eficaz através desta apresentação.

Em 2011, sob a argumentação de adequar o código de processo penal aos tratados e convenções firmados pelo Brasil, foi apresentado o Projeto de Lei do Senado $\mathrm{n}^{\mathrm{o}} 554$ de $2011^{112}$ que remodela o Art. $306^{\circ} \mathrm{CPP}$ para firmar

\footnotetext{
111 Art. 306 - A prisão de qualquer pessoa e o local onde se encontre serão comunicados imediatamente ao juiz competente e à família do preso ou a pessoa por ele indicada.

$\S 1^{\circ}$ - Dentro em $24 \mathrm{~h}$ (vinte e quatro horas) depois da prisão, será encaminhado ao juiz competente o auto de prisão em flagrante acompanhado de todas as oitivas colhidas e, caso o autuado não informe o nome de seu advogado, cópia integral para a Defensoria Pública.

${ }^{112}$ Em 6 de setembro de 2011 o Senador Antônio Carlos Valadares apresentou o PLS no 554/2011 com o fito de inserir a apresentação pessoal do preso na prática processual brasileira, alterando o Art. $306 \S 1^{\circ} \mathrm{CPP}$. O projeto inicial em trâmite no Senado Federal recebeu inúmeras emendas, e em 2015 após o parecer da Comissão de Constituição, Justiça e Cidadania, apreciado pela Comissão de Assuntos Econômicos (CAE) e Comissão de Direitos Humanos e Legislação Participativa $(\mathrm{CDH})$, foi conferida a seguinte redação ao Art. 306 CPP: “Art. 306. A prisão de qualquer pessoa e o local onde se encontre serão comunicados imediatamente pelo delegado de polícia responsável pela lavratura do auto de prisão em flagrante ao juiz competente, ao Ministério Público e à Defensoria Pública quando não houver advogado habilitado nos autos, bem como à família do preso ou à pessoa por ele indicada.

$\$ 1^{\circ} \mathrm{Em}$ até 24 (vinte e quatro) horas após a realização da prisão, será encaminhado pelo delegado de polícia ao juiz competente e ao Ministério Público o auto de prisão em flagrante e, caso o autuado não informe o nome de seu advogado, cópia integral para a Defensoria Pública respectiva. $\S 2^{\circ}$ No mesmo prazo, será entregue ao preso, mediante recibo, a nota de culpa, assinada pelo delegado de polícia, com o motivo da prisão, capitulação jurídica, o nome do condutor e os das testemunhas.

$\S 3^{\circ}$ Imediatamente após a lavratura do auto de prisão em flagrante, diante da ocorrência de suposta violação aos direitos fundamentais da pessoa presa, o delegado de polícia em despacho fundamentado determinará a adoção das medidas cabíveis para a preservação da integridade do preso, além de determinar a apuração das violações apontadas, instaurando de imediato inquérito
} 
que o custodiado deverá ser apresentado pessoalmente a um juiz no período

máximo de 24 horas após a prisão. Entretanto, até hoje, essa lei não entrou em vigor no ordenamento jurídico brasileiro.

\author{
Basicamente, essa iniciativa legislativa foi o marco para a \\ inauguração das discussões acerca da incorporação da Audiência de \\ Custódia no Brasil.
}

\author{
Sabiamente ilustram os juristas Mauro Fonseca Andrade e Pablo \\ Rodrigo Alfen acerca da realidade forense durante esse período:
}

Em meio essa indefinição em âmbito legislativo, o Poder Judiciário brasileiro começou a emitir suas primeiras posições sobre o tema, ora entendendo pela autoaplicabilidade dos tratados e convenções - obviamente ratificados pelo Brasil

policial para apuração dos fatos, requisitando a realização de perícias, exames complementares, também determinando a busca de outros meios de prova cabíveis.

$\S 4^{\circ}$ No prazo máximo de 24 (vinte e quatro) horas após a lavratura do auto de prisão em flagrante, o preso será conduzido à presença do juiz para ser ouvido, com vistas às medidas previstas no art. 310 e para que se verifique se estão sendo respeitados seus direitos fundamentais, devendo a autoridade judiciária tomar as mediadas cabíveis para preservá-los e para apurar eventual violação $\S 5^{\circ} \mathrm{Na}$ Audiência de Custódia de que trata o parágrafo quarto, o juiz ouvirá o Ministério Público, que poderá, caso entenda necessária, requerer a prisão preventiva ou outra medida cautelar alternativa à prisão, em seguida, ouvirá o preso e, após manifestação da defesa técnica, decidirá fundamentadamente, nos termos do art. 310

$\S 6^{\circ}$ A oitiva a que se refere o parágrafo anterior será registrada em autos apartados, não poderá ser utilizada como meio de prova contra o depoente e versará, exclusivamente, sobre a legalidade e necessidade da prisão; a prevenção da ocorrência de tortura ou de maus-tratos; e os direitos assegurados ao preso e ao acusado.

$\S 7^{\circ}$ A oitiva do preso em juízo sempre se dará na presença de seu advogado, ou, se não tiver ou não o indicar, na de Defensor Público, e na do membro do Ministério Público, que poderão inquirir o preso sobre os temas previstos no parágrafo sexto, bem como se manifestar previamente à decisão judicial de que trata o art. 310 .

$\S 8^{\circ} \mathrm{Na}$ impossibilidade, devidamente certificada e comprovada, da autoridade judiciária realizar a inquirição do preso quando da sua apresentação, a autoridade custodiante ou o delegado de polícia, por meio de seus agentes, tomará recibo do serventuário judiciário responsável, determinando a juntada nos autos neste último caso, retornando com o preso e comunicando o fato de imediato ao Ministério Público, à Defensoria Pública e ao Conselho Nacional de Justiça.

$\S 9^{\circ}$ Tendo em vista a necessidade de garantir os direitos fundamentais da pessoa presa, a Audiência de Custódia deverá ser obrigatoriamente realizada no primeiro dia útil subsequente, devendo a autoridade custodiante, sob pena de responsabilidade, reapresentá-lo na data indicada.

$\S 10$ Nos casos de crimes de competência da Polícia Federal, quando o município do local da lavratura do flagrante delito não coincidir com sede da Justiça Federal, a autoridade custodiante ou o delegado de polícia federal deverá determinar a seus agentes que conduza o preso ao Juízo de Direito do local da lavratura da peça flagrancial no prazo máximo de vinte e quatro horas, ocasião em que deverá ser apresentado o auto de prisão em flagrante acompanhado de todas as oitivas colhidas e, caso o autuado não informe o nome de seu advogado, cópia integral para a Defensoria Pública. Disponível em:

$<\mathrm{http}$ //www.senado.leg.br/atividade/rotinas/materia/getPDF.asp?t=172861\&tp=1\#Emenda10>. Acesso em: 25 ago.2016.

Disponível em: <https://www25.senado.leg.br/web/atividade/materias/-/materia/102115)>.

Acesso em: 25 ago.2016. 
- que fazem referência a audiência de custodia, ora entendendo por sua desnecessidade (...). Sem exagero nenhum, é possível afirmar que entre os anos de 2014 e 2015, a não realização dessa audiência foi carro-chefe das manifestações defensivas objetivando o relaxamento da prisão preventiva daqueles indivíduos que haviam sido presos em flagrante. Em uma situação isolada e de forma independente, o Tribunal de Justiça do Maranhão chegou a emitir uma resolução disciplinando a forma como deveria se dar aquele ato na capital do seu Estado ${ }^{113}$.

Diante o descumprimento das disposições instituídas pelos tratados internacionais ratificados pelo Brasil na pratica judicial associado ao indecoroso quadro carcerário brasileiro, o Conselho Nacional de Justiça ${ }^{114}$, conjuntamente com o Ministério da Justiça e com o Tribunal de Justiça de São Paulo, implementou o Projeto Audiência de Custódia no Estado de São Paulo em 2015. O TJSP instituiu o Provimento nº3/15 em janeiro de 2015, regulamentando o mecanismo procedimental da Audiência de Custódia. O Estado paulista seria o ponto de partida para a implementação do instituto, tirando-se como experiência os pontos positivos e negativos para a futura disseminação deste por todo o Brasil.

Em razão do sucesso do "projeto-modelo" em São Paulo, vários outros Estados foram aderindo a implementação da Audiência de Custodia em seus territórios, possuindo cada Tribunal de Justiça discricionariedade para regulamentar o funcionamento do instituto.

O provimento que norteava a atuação da Audiência de Custódia no Estado São Paulo foi o propósito da Ação Direita de Inconstitucionalidade (ADI 5240) interposta pela Associação dos Delegados de Polícia do Brasil. Questionava-se que a competência para legislar sobre a matéria de direito

\footnotetext{
${ }^{113}$ ANDRADE; ALFLEN, 2016, p. 12.

${ }^{114}$ A Emenda Constitucional n. 45 (EC 45), promulgada em dezembro de 2004 e conhecida como a Reforma do Judiciário, trouxe como principal novidade a criação do Conselho Nacional de Justiça (CNJ). (...) a sua natureza de "órgão exclusivamente administrativo", com atribuições de controle financeiro e disciplinar da Magistratura e com competência em relação aos órgãos e juízes situados, hierarquicamente, abaixo do Supremo Tribunal Federal (STF). (...) focados no planejamento estratégico e na indução de mudanças, a partir de visão moderna de diálogo e participação democrática dos atores da cena judiciária, especialmente os juízes.

SCHMIDT, Paulo Luiz et al.. Livro Digital - CNJ 10 Anos. 2015. p. 12. Disponível em: <http://www.cnj.jus.br/files/conteudo/arquivo/2016/02/09dc2798333678820c2c7d6ba61fc067.pdf >. Acesso em: 22 ago.2016.
} 
processual penal e penal é exclusiva da União o que configuraria o caráter inconstitucional de tal provimento criado pelo Tribunal de São Paulo.

A ADI não foi provida. Com a alegação de que o Pacto de San José, o qual prevê o fundamento da Audiência de Custódia em seu Art. $7^{\circ}$ item 5, já havia sido recepcionado pelo ordenamento jurídico brasileiro através do Decreto Lei $n^{\circ}$ 678/92, não se tratava o provimento do TJSP da criação de um novo instituto jurídico, e sim apenas de regramentos internos ${ }^{115}$ de cunho administrativo, destinados a organizar os serviços prestados.

Sabiamente em seu voto o Ministro Luiz Fux, relator da ADI, deu credibilidade a iniciativa da Audiência de Custodia mencionando:

\begin{abstract}
A proposta das audiências de custodias, capitaneada pelo Conselho Nacional de Justiça e encampada por diversos tribunais do país, sem dúvida é das mais relevantes nessa seara, como provam os resultados hauridos até então pelas cortes pioneiras: redução de $50 \%$ das prisões cautelares no TJEJ e redução de $40 \%$ das prisões cautelares no TJSP, no primeiro mês de realização das audiências de custodia, além da estimativa de economia de 75 milhões de reais por ano com gastos no sistema penitenciário do Estado do Paraná e de 27 milhões de reais por ano no Amazonas ${ }^{116}$.
\end{abstract}

Após o julgamento da ADI, foi proposta pelo PSOL ${ }^{117}$ uma Ação de Arguição de Descumprimento de Preceito Fundamental (ADPF 47) no STF em defesa dos direitos humanos da população carcerária. Teve como objeto as violações das garantias constitucionais, as condições sub-humanas e indignas que são impostas aos presos e pedia-se, liminarmente, a obrigatoriedade da realização das Audiências de Custódia.

No julgamento da ADPF 347, o Supremo Tribunal Federal determinou o caráter obrigatório da apresentação da pessoa presa a

\footnotetext{
115 Art. $96 \mathrm{CF}$ - Compete privativamente:

I - aos tribunais:

a) eleger seus órgãos diretivos e elaborar seus regimentos internos, com observância das normas de processo e das garantias processuais das partes, dispondo sobre a competência e o funcionamento dos respectivos órgãos jurisdicionais e administrativos;

${ }^{116}$ STF, ADI n. 5240/SP, Rel. Ministro Luiz Fux, Brasília, 20 ago. 2015.

${ }^{117}$ Partido Socialismo e Liberdade.
} 
autoridade judicial competente. O Ministro Relator Marco Aurelio, relator da ADPF, ressalta em seu voto:

AUDIÊNCIA DE CUSTÓDIA - OBSERVÂNCIA OBRIGATÓRIA. Estão obrigados juízes e tribunais, observados os artigos 9.3 do Pacto dos Direitos Civis e Políticos e 7.5 da Convenção Interamericana de Direitos Humanos, a realizarem, em até noventa dias, audiências de custódia, viabilizando o comparecimento do preso perante a autoridade judiciária no prazo máximo de 24 horas, contado do momento da prisão. (...) audiência de custodia, instrumento ao qual o ministro Ricardo Lexandowski, como Presidente do Conselho Nacional de Justiça - CNJ, vem dando atenção especial, buscando torna-lo realidade concreta, no Judiciário, em diferentes unidades federativas e combatendo a cultura do encarceramento. A imposição da realização de audiências de custodias há de ser estendida a todo o Poder Judiciário do país. A medida está prevista nos artigos 9.3 do Pacto dos Direitos Civis e Políticos e 7.5 da Convenção Interamericana de Direitos Humanos, já internalizados no Brasil. O que lhes confere hierarquia legal. A providência conduzirá, de início, a redução da superlotação carcerária, além de implicar diminuição considerável dos gastos com a custodia cautelar - o custo médio mensal individual seria, aproximadamente, de $\mathrm{R} \$ 2.000,00$. A pretensão também merece acolhimento ${ }^{118}$.

A decisão proferida pelo STF tanto no julgamento da referida ADI quanto no julgamento da ADPF, tiveram um papel relevante para a efetivação da Audiência de Custódia diante a afirmação da autoaplicabilidade das regras normativas provenientes dos tratos internacionais de direitos humanos ratificados pelo Brasil.

Efeito prático do sucesso do projeto-piloto em São Paulo e das decisões do STF foi que até o final de 2015 , todos ${ }^{119}$ os Tribunais de Justiça do país já haviam instituído a Audiência de Custódia nas capitais dos Estados brasileiros.

Cada unidade da Federação acabou disciplinando o tema de forma própria, pois os Tribunais (Estaduais e Federais), tinham discricionariedade para regulamentar seus provimentos quanto ao trâmite da Audiência de Custódia, em razão da inexistência de um modelo legislativo que vinculasse todos os Tribunais em caráter nacional e padronizado.

\footnotetext{
${ }^{118}$ STF, ADPF n. 347, Rel. Ministro Marco Aurélio, Brasília, 27 ago. 2015.

119 Disponível em: <http://www.cnj.jus.br/sistema-carcerario-e-execucao-penal/audiencia-decustodia/mapa-da-implantacao-da-audiencia-de-custodia-no-brasil>. Acesso em: 2 set. 2016.
} 
Em dezembro de 2015, o CJN regulamentou através da Resolução ${ }^{120}$ $n^{\circ} 213 / 2015$, o funcionamento das audiências de custodias em todo o pais. Essa resolução, apesar de não se tratar de uma norma legal, visa proporcionar uma padronização da Audiência de Custodia em todos os estados da Federação.

\subsubsection{Resolução no $213 \mathrm{CNJ}$}

Conforme os estudos já evidenciados no presente trabalho, apesar de duas décadas da ratificação dos tratados que conferem os fundamentos da Audiência de Custódia pelo Brasil, o grande preceptor para sua efetividade não foi o Poder Legislativo e sim o Poder Judiciário, através do CNJ e do Supremo Tribunal Federal.

Diante o limbo legislativo quanto a implementação do instituto da Audiência de Custódia no país, o CNJ em parceria com o Ministério da Justiça deu início ao projeto Audiência de Custódia que, começando pelo estado de São Paulo visava a disseminação gradativa do instituto por todos os estados da Federação. Com o apoio do Supremo Tribunal Federal os estados foram aderindo ao projeto de modo que a apresentação breve do preso a autoridade judicial virou realidade em $\operatorname{todas}^{121}$ as capitais do Brasil.

\footnotetext{
120 (...) aprovando resoluções de caráter estratégico, focadas nos princípios constitucionais que regem a Administração Pública e voltadas para a valorização da instituição judiciária, da Magistratura e da gestão eficiente e transparente. (...) ao longo desses dez anos de história, o CNJ debruçou-se sobre temas importantes que o aproximou da sociedade, entre outros o combate ao nepotismo, como citado anteriormente, o incentivo à conciliação, a Jornada Maria da Penha, a criação do Cadastro Nacional de Adoção, o projeto Começar de Novo, o programa Pai Presente, a preocupação com as regras para a viagem ao exterior de crianças e adolescentes, o casamento civil homoafetivo, o enfrentamento do tráfico de pessoas e, mais recentemente, as audiências de custódia. Iniciativas como essas comprovam que há muito mais além da competência correicional e que apontam para aquilo que a sociedade e a Magistratura esperam do CNJ: que pense estrategicamente o Poder Judiciário e atue em prol da melhoria da prestação jurisdicional para a sociedade. SCHMIDT, Paulo Luiz et al.. Livro Digital - CNJ 10 Anos. 2015. p. 13,17. Disponível em:<http://www.cnj.jus.br/files/conteudo/arquivo/2016/02/09dc2798333678820c2c7d6ba61fc067. pdf $>$. Acesso em: 22 ago.2016.

121 Disponível em: <http://www.cnj.jus.br/sistema-carcerario-e-execucao-penal/audiencia-decustodia/mapa-da-implantacao-da-audiencia-de-custodia-no-brasil >. Acesso em: 2 set.2016.
} 
Após atingir o objetivo da disseminação do projeto por todo o país, o CNJ caminhou para a construção de um modelo de regulamentação que uniformizasse o procedimento da Audiência de Custódio em todo o território nacional, já que cada um dos Estados, através do suas respectivas Cortes, disciplinou o tema de forma própria.

Para adentramos na questão quanto a essência da Resolução no 213, faz-se necessário tecer, previamente, as seguinte ponderações: o Conselho Nacional de Justiça ${ }^{122}$ (CNJ) é um órgão administrativo do Poder Judiciário que possui legitimidade ${ }^{123}$ para expedir atos normativos administrativos vinculativos ${ }^{124}$ por meio de Resoluções ${ }^{125}$, no âmbito de sua competência, taxativamente ${ }^{126}$ prevista no texto constitucional.

${ }^{122}$ Art. 92 CF - São órgãos do Poder Judiciário:

I-A o Conselho Nacional de Justiça; (Incluído pela Emenda Constitucional no 45, de 2004).

(...) desde a instalação do CNJ em 2005, o Poder Judiciário se tornou órgão bicéfalo, tendo um órgão de cúpula para os assuntos administrativos, financeiros e disciplinares (exatamente o CNJ) e outro para as questões jurisdicionais (Supremo Tribunal Federal, STF), embora sempre possa haver impugnação dos atos do CNJ perante o STF. O CNJ, como órgão do Poder Judiciário, desempenha seu papel em três eixos principais: a) atividade regulamentadora do Poder Judiciário, com exceção do STF; b) atividade de fiscalização e controle disciplinar da magistratura; e c) atividade de planejamento administrativo dos Tribunais.

SCHMIDT, Paulo Luiz et al.. Livro Digital - CNJ 10 Anos. 2015. p. 12. Disponível em:<http://www.cnj.jus.br/files/conteudo/arquivo/2016/02/09dc2798333678820c2c7d6ba61fc067. pdf>. Acesso em: 22 ago. 2016.

123 Art. $103-\mathrm{B}, \S 4^{\circ} \mathrm{CF}$ :

Compete ao Conselho o controle da atuação administrativa e financeira do Poder Judiciário e do cumprimento dos deveres funcionais dos juízes, cabendo-lhe, além de outras atribuições que lhe forem conferidas pelo Estatuto da Magistratura:

I - zelar pela autonomia do Poder Judiciário e pelo cumprimento do Estatuto da Magistratura, podendo expedir atos regulamentares, no âmbito de sua competência, ou recomendar providências; (...).

${ }^{124}$ Art. 102 - Regimento Interno CNJ:

O Plenário poderá, por maioria absoluta, editar atos normativos, mediante Resoluções, Instruções ou Enunciados Administrativos e, ainda, Recomendações.

$\S 5^{\circ}$ As Resoluções e Enunciados Administrativos terão força vinculante, após sua publicação no Diário da Justiça eletrônico e no sítio eletrônico do CNJ.

${ }^{125}$ Resolução é a fórmula de que se valem os órgãos colegiados para manifestar suas deliberações em assuntos da respectiva competência ou para dispor sobre seu próprio funcionamento. GASPARINI, Diógenes. Direito administrativo. São Paulo: Saraiva, 1995. p. 85.

${ }^{126}$ Art. $103-\mathrm{B} \$ 4^{\circ} \mathrm{CF}$ :

Compete ao Conselho o controle da atuação administrativa e financeira do Poder Judiciário e do cumprimento dos deveres funcionais dos juízes, cabendo-lhe, além de outras atribuições que lhe forem conferidas pelo Estatuto da Magistratura:

I - zelar pela autonomia do Poder Judiciário e pelo cumprimento do Estatuto da Magistratura, podendo expedir atos regulamentares, no âmbito de sua competência, ou recomendar providências; II - zelar pela observância do art. 37 e apreciar, de ofício ou mediante provocação, a legalidade dos atos administrativos praticados por membros ou órgãos do Poder Judiciário, podendo desconstituí- 
Pois bem, em dezembro de 2015, o CNJ criou a Resolução no 213 estabelecendo um modelo de regulamentação e uniformização da procedibilidade das Audiências de Custódia em todo o Brasil. Determinou também que os Tribunais de Justiça Estaduais e os Tribunais Regionais Federais tinham o prazo de 90 dias, desde a sua entrada em vigor, para aderirem às disposições ali previstas porém, não previu nenhuma sansão para o seu descumprimento.

Com o argumento de que ao regulamentar as Audiências de Custódia com caráter vinculativo em todo o país, estaria o CNJ legislando sobre matéria de Processo Penal ofendendo o Art. 22, I CF/88 ${ }^{127}$ e exorbitando a sua competência administrativa, a ANAMAGES (Associação Nacional dos Magistrados Estaduais) ajuizou uma Ação Direta de Inconstitucionalidade (ADI n ${ }^{\circ} 5448^{128}$ ) impugnando a inconstitucionalidade da Resolução no 213

O Supremo Tribunal Federal em decisão ${ }^{129}$ recente publicada no dia 10/02/2016, não chegou a se manifestar sobre o mérito da questão uma vez

\footnotetext{
los, revê-los ou fixar prazo para que se adotem as providências necessárias ao exato cumprimento da lei, sem prejuízo da competência do Tribunal de Contas da União;

III - receber e conhecer das reclamações contra membros ou órgãos do Poder Judiciário, inclusive contra seus serviços auxiliares, serventias e órgãos prestadores de serviços notariais e de registro que atuem por delegação do poder público ou oficializados, sem prejuízo da competência disciplinar e correicional dos tribunais, podendo avocar processos disciplinares em curso e determinar a remoção, a disponibilidade ou a aposentadoria com subsídios ou proventos proporcionais ao tempo de serviço e aplicar outras sanções administrativas, assegurada ampla defesa;

IV - representar ao Ministério Público, no caso de crime contra a administração pública ou de abuso de autoridade;

V - rever, de ofício ou mediante provocação, os processos disciplinares de juízes e membros de tribunais julgados há menos de um ano;

VI - elaborar semestralmente relatório estatístico sobre processos e sentenças prolatadas, por unidade da Federação, nos diferentes órgãos do Poder Judiciário;

VII - elaborar relatório anual, propondo as providências que julgar necessárias, sobre a situação do Poder Judiciário no País e as atividades do Conselho, o qual deve integrar mensagem do Presidente do Supremo Tribunal Federal a ser remetida ao Congresso Nacional, por ocasião da abertura da sessão legislativa.

${ }^{127}$ Art. 22-CF: Compete privativamente à União legislar sobre:

I - direito civil, comercial, penal, processual, eleitoral, agrário, marítimo, aeronáutico, espacial e do trabalho.

${ }^{128}$ Disponível em: <http://s.conjur.com.br/dl/adi-anamages-audiencias-custodia.pdf>. Acesso em: 2 set. 2016.

${ }^{129}$ Disponível em:

$<$ http://juris.cjcplp.org/portal/processo/verProcessoAndamento.asp?numero=5448\&classe=ADI\&o rigem $=$ AP\&recurso=0\&tipoJulgamento=M/> . Acesso em: 2 set. 2016.
} 
que negou seguimento a ADI por entender que a ANAMAGES não possui legitimidade ativa para ajuizar a ação vez que, o ato impugnado repercute sobre toda a classe judiciaria em caráter nacional e não somente a categoria que representa (juízes estaduais).

Segundo Luís Lanfredi ${ }^{130}$, coordenador do Departamento de Monitoramento e Fiscalização do Sistema Carcerário e juiz auxiliar da presidência do Conselho Nacional de Justiça durante a presidência do Ministro Ricardo Lewandowski:

A atuação do Conselho Nacional de Justiça neste momento não muda o que está sendo feito, mas dá muito mais subsídios e determina, impõem, um protocolo mais rígido, mais uniforme, de uma maneira mais equilibrada, dos deveres e obrigações dos juízes em relação a estas audiências de custódia ${ }^{131}$.

Na prática, apesar da Resolução no 213 CNJ conferir um caráter obrigatório ao cumprimento das suas disposições, esta foi recepcionada pelos Tribunais Estaduais e Federais como uma orientação/instrução para que os magistrados possam nortear o procedimento da Audiências de Custódia.

Por tratar-se de uma temática recente, acredita-se que muito se tem a debater sobre o assunto mas faz-se necessário ressaltar que este tema carece de uma regulamentação legislativa. Somente se alcançará a padronização do mecanismo da Audiência de Custódia, com a devida criação de uma lei emanada pelo Poder Legislativo normatizando o tema.

130 Disponível em: <http://www.cnj.jus.br/sistema-carcerario-e-execucao-penal/contatos-dmf $>$. Acesso em: 2 set. 2016.

131 Disponível em: <http://agenciabrasil.ebc.com.br/geral/noticia/2016-01/cnj-publica-resolucaoque-regulamenta-audiencias-de-custodia $>$. Acesso em: 5 set. 2016. 


\subsection{Aspectos gerais da Audiência de Custódia}

\subsubsection{Finalidades}

O tema da Audiência de Custódia surgiu na pauta dos assuntos do CNJ após a verificação do quadro crítico do sistema carcerário brasileiro. Verificou-se ${ }^{132}$ que o Brasil, em 2014, possuía mais de 600.000 mil presos e que $41 \%$ da população carcerária era composta de presos provisórios. Era preciso um meio para combater o número exorbitante dos encarcerados sem sentença penal condenatória.

A apresentação pessoal do preso ao magistrado após a prisão foi idealizada como uma possível solução para a redução das abundantes decisões que convertiam prisões em flagrantes em prisões preventivas.

O magistrado após a análise do APF, tende a deliberação "automática" da conversão da prisão em flagrante em prisão preventiva, mesmo quando presentes os requisitos para a concessão da liberdade provisória. Isto muito se deve à cultura do encarceramento vivenciada nos dias atuais. O "olhar" do magistrado para o custodiado na audiência, humaniza a relação juiz-preso e possibilita que o magistrado disponha de mais subsídios e informações acerca do preso e do ato da prisão. Desta forma, há um aumento significativo das chances de deliberações favoráveis ao status libertatis do custodiado.

Conforme instrui Pedro Abramovay, Diretor da Open Society Foundations para a América Latina e ex-secretário Nacional de Justiça, acerca da temática:

A medida tinha um claro propósito de evitar manutenção de prisões provisórias (...). Basicamente está-se obrigando o juiz a tomar a decisão olhando para uma pessoa e não para um papel. Ou seja, o juiz já era obrigado a decidir baseado nas mesmas leis. Mas agora ele deve fazer isso diante da presença física do réu. (...) aparentemente esse contato pessoal entre juiz e réu tem feito diferença. Continuo

${ }^{132}$ INFOPEN, Levantamento Nacional de Informações Penitenciária. Acesso em: 15 ago. 2016. 
acreditando que a presença física do réu frente a frente ao juiz, em substituição ao mero processo foi um elemento central para o aumento das solturas. Os momentos reais de dúvidas dos juízes olhando nos olhos dos réus não existiriam se fossem apenas processos de papel ${ }^{133}$.

Além do principal propósito do Projeto da Audiência de Custódia no Brasil reportado anteriormente, o instituto possui outras três finalidades basilares: (a)fiscalizar possíveis incidentes que envolvam atos de violência praticados contra o detido em sede policial, (b)averiguar a legalidade da prisão inibindo eventuais abusos e arbitrariedades provenientes do Estado e (c) proporcionar ao juiz mais subsídios e informações para deliberar acerca da possibilidade da liberdade provisória (com ou sem a imposição de medidas cautelares) ou da manutenção do encarceramento.

\subsubsection{Preservar a integridade física e psíquica do conduzido}

De acordo com o que expõem Pablo Rodrigo Alffen acerca da temática:

O simples fato de se tratar de instituto processual decorrente de Tratado Internacional Protetivo de Direitos Humanos já permitiria concluir, de imediato, ser objetivo da audiência de custodia, proceder ao asseguramento dos direitos humanos da pessoa presa. De modo mais específico, ser o principal objetivo da audiência de custodia fazer cessar ou evitar o risco de incidência de um dos principais problemas verificados nessa fase inicial da persecução penal, que é a ocorrência de violações a incolumidade física e/ou psíquica, tais como tortura e maus tratos dos indivíduos que tiverem sua liberdade privada ${ }^{134}$.

Os imperativos previstos no Pacto de San José da Costa Rica no Art. $5^{\circ}$ item 2 e na Convenção Contra a Tortura e Outros Tratamentos ou Penas Cruéis Desumanos ou Degradantes (Decreto Lei $n^{\circ}$ 40/1991) em seu Art. $2^{\circ}$ item 1, são um dos pilares da Audiência de Custódia.

Art. $5^{\circ}$. Direito à integridade pessoal

\footnotetext{
${ }^{133}$ ABRAMOVAY, Pedro. Banalidade do réu: um dia de observação das audiências de custódia. Disponível em: <http://jota.info/banalidade-reu-um-dia-de-observacao-das-audiencias-decustodia>. Acesso em: 1 nov. 2016.

${ }^{134}$ ANDRADE; ALFLEN, 2016, p. 61.
} 
2. Ninguém deve ser submetido a torturas, nem a penas ou tratos cruéis, desumanos ou degradantes. Toda pessoa privada da liberdade deve ser tratada com o respeito devido à dignidade inerente ao ser humano.

Art. $2^{\circ}$

1. Cada Estado Parte tomará medidas eficazes de caráter legislativo, administrativo, judicial ou de outra natureza, a fim de impedir a prática de atos de tortura em qualquer território sob sua jurisdição.

A Organização Internacional Human Right Watch ${ }^{135}$, engajada com a erradicação da prática de tortura no mundo, divulgou um relatório de 117 páginas denominado “'O Bom Policial Tem Medo’: Os Custos da Violência Policial no Rio de Janeiro"136 documentando que nas últimas décadas, somente no Rio de Janeiro, mais de 8.000 pessoas foram mortas por policiais, incluindo o número mínimo de 645 vítimas só em 2015.

Uma outra pesquisa realizada pela Human Right Watch em 2010 acompanhou de perto 64 casos que resultaram em prisão nos estados do Rio de Janeiro, São Paulo, Espírito Santo, Bahia e Paraná, e verificou que 40 destes constavam fortes indícios de que agentes estatais cometeram maustratos, tortura e submeteram os detidos a tratamentos desumanos. Foi apurado, inclusive, que a maioria dessas violações foram cometidas nas

\footnotetext{
135 “A Human Rights Watch é uma organização internacional de direitos humanos, nãogovernamental, sem fins lucrativos, contando com aproximadamente 400 membros que trabalham em diversas localidades ao redor do mundo. Nossa equipe é composta por profissionais de direitos humanos como advogados, jornalistas e especialistas e acadêmicos de diversas origens e nacionalidades. Fundada em 1978, a Human Rights Watch é reconhecida por investigações aprofundadas sobre violações de direitos humanos, elaboração de relatórios imparciais sobre essas investigações e o uso efetivo dos meios de comunicação para informar e sensibilizar diversos públicos sobre suas causas. Contando com o apoio de organizações locais de direitos humanos, publicamos mais de 100 relatórios e artigos sobre direitos humanos em todo o mundo todo os anos. A partir de casos concretos de violações, a HRW se reúne com governos e organizações internacionais para propor políticas públicas e reformas legais necessárias para proteger direitos e garantir a reparação para vítimas de violações passadas". Disponível em: <https://www.hrw.org/pt/sobre-human-rights-watch>. Acesso em: 1 nov. 2016.

136 Brasil: Execuções Extrajudiciais Comprometem a Segurança Pública no Rio. Disponível em: <https://www.hrw.org/pt/news/2016/07/07/291657>. Acesso em: 1 nov. 2016.
} 
primeiras horas da prisão e que 23 desses casos foram praticados somente no estado de São Paulo ${ }^{137}$.

Em 2016 o relator especial sobre tortura da ONU Juan E. Méndez, em visita ao Brasil denunciou em seu relatório ${ }^{138}$ que a prática de tortura e maus tratos são práticas frequentes no Brasil e ocorrem, com mais evidência, durante o momento da prisão.

O paradigma de aceitação da prática de tortura contra os presos é, muitas vezes, aplaudido pela sociedade. Este quadro social "legitima" a pratica corriqueira de violência por meio dos agentes estatais e a inobservância de punições aos policias que praticam estes crimes.

A Audiência de Custodia é um mecanismo de combate à violência praticada contra os presos em sede policial, através da fiscalização do Poder Judiciário. Motivo pelo o qual, esta deve ser realizada o mais rápido possível para que o juiz possa verificar a ocorrência de abusos por parte dos agentes estatais.

Na audiência, o juiz indagará ${ }^{139}$ sobre possíveis ocorrências de tortura e maus tratos contra o preso em sede policial, devendo o magistrado tomar providências cabíveis, determinando a realização de corpo de delito. Além disso, deve o magistrado encaminhar os relatos de maus tratos para os órgãos responsáveis pela apuração das denúncias e responsabilização desses policias.

137 Brasil: Reformas Foram Insuficientes para Coibir Tortura. Disponível em: <https://www.hrw.org/pt/news/2014/07/28/254675>. Acesso em: 1 nov. 2016.

138 Disponível em: <http://www.global.org.br/wp-content/uploads/2016/03/Relatorio-JuanMendez-Espanhol-3.pdf>. Acesso em: 1 nov. 2016.

${ }^{139}$ Art. $8^{\circ}$ Resolução no 213 CNJ - Na Audiência de Custódia, a autoridade judicial entrevistará a pessoa presa em flagrante, devendo:

VII - verificar se houve a realização de exame de corpo de delito, determinando sua realização nos casos em que:

a) não tiver sido realizado;

b) os registros se mostrarem insuficientes;

c) a alegação de tortura e maus tratos referir-se a momento posterior ao exame realizado;

d) o exame tiver sido realizado na presença de agente policial, observando-se a Recomendação CNJ 49/2014 quanto à formulação de quesitos ao perito. 


\subsubsection{Analisar a legalidade da prisão}

A prisão em flagrante é efetuada sem o crivo do Judiciário e por isso, está mais propensa a abusos e ilegalidades. A exigência do cumprimento das suas formalidades, conforme dita o código processual penal, é uma maneira de evitar descomedimento por parte do Estado.

É essencial que a prisão em flagrante seja prontamente comunicada para que o juiz possa averiguar se foram cumpridos os requisitos previstos na lei para a decretação da prisão. A forma mais eficiente para que o magistrado possa certificar-se dessa situação, não é com a simplória remessa do auto de prisão em flagrante e sim, mediante a apresentação pessoal do preso.

O magistrado deverá questionar o custodiado acerca das circunstâncias em que se efetuou a prisão. Assim, a apresentação pessoal proporciona que o preso forneça a sua versão sobre os fatos. $\mathrm{O}$ contato pessoal com o detido, permite uma melhor averiguação se a prisão foi efetuada conforme os ditames da lei, segundo o princípio da legalidade. A celeridade que a apresentação do preso ao magistrado deve ocorrer, é justificada como uma maneira de salvaguardar os direitos do custodiado.

A apresentação pessoal dever ser realizada de maneira mais breve possível pois, diante um eventual abuso do Estado, é possível reduzir os efeitos maléficos oriundos da decretação ilegal da prisão como por exemplo a inserção de um indivíduo em um presídio vivendo sob condições degradantes e o seu contato com presos perigosos.

Conforme leciona Douglas Fischer acerca da temática:

Por este contato pessoal e mediante o questionamento específico, será possível reduzir - e muito - eventuais dissensos que existam entre o contido nos documentos legais exigidos e a narrativa apresentada pelo preso. Ainda: não se pode olvidar que, em alguns casos, a prisão em flagrante poderá ser realizada por 
qualquer pessoa, nos termos do Art. $301 \mathrm{CPP}$, justificando, mais ainda, a cautela de deixar bem claras as circunstâncias em que se deu o ato de prisão ${ }^{140}$.

\subsubsection{Medidas cautelares de ordem pessoal}

Desde a implementação do rol das medidas cautelares no Art. 319 CPP pela Lei $\mathrm{n}^{\circ} 12.403 / 2011$, estas se demonstraram eficientes para manter o indivíduo sob vigilância do Estado sem que seja necessário decretar a sua prisão, reduzindo assim o contingente carcerário.

Pesquisas $^{141}$ demonstram que uma das principais causas da superlotação dos presídios são os presos provisórios. Muitos destes tratamse de presos que, na maioria das vezes, são primários, de bons antecedentes e que cometeram crimes de baixo/médio potencial ofensivo (sem violência, como furto por exemplo).

Estes se encaixam perfeitamente nas condições previstas pela lei para responderem ao processo em liberdade pois, a sentença para esses crimes pode ser substituída por medidas restritivas de direitos diversas da prisão, por exemplo. A realidade demonstra que mesmo nesses casos, os detidos passam anos em prisões superlotadas, com condições precárias e convivendo com presos perigosos, antes de terem o seu primeiro contato com o juiz.

A Audiência de Custodia visa, principalmente, "beneficiar" esses indivíduos que cumprem os requisitos para responder ao processo em liberdade, com ou sem a imposição de medidas cautelares diversas do encarceramento, no entanto, na prática, têm a sua prisão preventiva decretada e são esquecidos nas celas dos presídios.

É ilusório acreditar que diante uma demanda diária e cada vez mais crescente de autos de prisão em flagrante, ser oportuno ao magistrado

\footnotetext{
140 PAIVA, 2016, p. 99.

${ }^{141}$ INFOPEN, Levantamento Nacional de Informações Penitenciária. Acesso em: 15 ago. 2016.
} 
analisar minuciosamente as circunstâncias pessoais de cada detido para deliberar acera da imposição de alguma medida provisória pertinente ao caso concreto. $\mathrm{Na}$ prática, percebe-se que a prisão provisória é ainda a primeira medida cautelar a ser considerada pelos magistrados, mesmo quando o detido cumpre os requisitos para responder ao processo/investigação criminal em liberdade.

A humanização da relação juiz-detido proporcionada pela Audiência de Custodia, visa oportunizar ao magistrado o conhecimento, mais eficaz, de todas as circunstâncias pessoais do detido (como por exemplo questionamentos sobre residência fixa, trabalho fixo, ocupações) de modo que o juiz possa deliberar, da melhor forma possível, acerca da concessão da liberdade provisória do detido com, ou sem a concessão de medidas cautelares adequadas.

A Audiência de Custódia não possui o fim de abrandar os requisitos para a decretação da prisão provisória, uma vez que estes permanecem os mesmos. Objetiva apenas proporcionar ao magistrado melhores possibilidade para analisar as condições pessoais do detido (através de questionamentos sobre a ocupação do preso, se o preso possui residência fixa ou trabalho fixo por exemplo) e aplicar, aos que fizerem jus ao benefício, medidas cautelares diversas da prisão.

Desta maneira, além de se estar salvaguardando os direitos do detido (responder ao processo criminal e a investigação criminal em liberdade é a regra de acordo com o princípio da presunção de inocência) estar-se-á reduzindo o quadro de superlotação dos presídios.

\subsubsection{Princípios assegurados na Audiência de Custódia}

\subsubsection{Presunção de inocência}


O princípio da presunção inocência comporta a premissa de que ninguém será considerado culpado antes do trânsito em julgado da sentença penal. Corolário do Estado Democrático de Direito e princípio basilar do sistema acusatório, garante, como regra geral, a liberdade do réu durante a instrução e o processo criminal arquitetando, por consequência, o caráter excepcional da prisão cautelar.

O princípio da presunção de inocência garante, rigorosamente, a decretação da prisão preventiva em casos excepcionais e somente como ultima ratio uma vez que, vigora no sistema acusatório a proteção do réu (possível inocente) contra arbítrios de um Estado punitivo.

Infelizmente, na sociedade na qual vivemos hoje o princípio da presunção de inocência vem sendo denegrido na seara do direito processual penal, principalmente no que se refere as excessivas decisões que decretam prisões preventivas.

A Audiência de Custódia reforça a garantia da presunção de inocência do custodiado ao idealizar, através da humanização da relação juiz-preso, a diminuição da decretação das prisões preventivas sem necessidade.

\subsubsection{Dignidade da Pessoa Humana}

A Audiência de Custódia permite um controle mais efetivo do Poder Judiciário em relação aos casos de violência praticados contra os detidos em sede policial.

Além disso, a apresentação pessoal ao magistrado possibilita que o juiz recolha elementos de convicção mais eficientes que identifique prisões ilegais e arbitrárias relaxando o mais rápido possível a prisão e concedendo a liberdade provisória para os indivíduos que demonstrem condições favoráveis ao exercício desse direito. Evita-se que, nesses casos, um 
indivíduo seja ilegalmente submetido às condições precárias dos presídios e ao contato com presos perigosos.

\subsubsection{Ampla Defesa}

Diante a posição hipossuficiente do réu frente a força Estatal na relação jurídica processual, o princípio da ampla defesa garante todos os meios para que a parte mais fraca exerça sua defesa das acusações.

A defesa técnica é realizada por um defensor e a autodefesa, por sua vez, é aquele realizada pelo próprio indivíduo.

É direito do preso de ser apresentado à um juiz o mais breve possível após a sua prisão em flagrante, para que ele possa contar a sua versão dos fatos. Como se vislumbra na prática, a simples comunicação da prisão ao juiz pelo APF não é suficiente para que o magistrado reúna elementos suficientes para deliberar acerca do relaxamento, manutenção da prisão ou concessão da liberdade provisória.

Quando a prisão em flagrante é convolada em prisão preventiva pelo auto de prisão em flagrante delito, o preso, principalmente os que não que possuem recursos financeiros, são esquecidos nas celas das cadeias, e somente possuem o seu primeiro contato com o magistrado na audiência de instrução em julgamento, mas especificamente no ato do interrogatório (último ato da fase da instrução). O interrogatório é a única possibilidade que o réu possui de ter contato pessoal com o juiz e contar a sua versão sobre os fatos.

Com a Audiência de Custódia, há uma extensão do direito à ampla defesa pois o detido passa a ter o direito de ser ouvido pelo juiz logo após ter o seu direito de liberdade cerceado e contato com o seu defensor (Defensor Público ou advogado) antes da audiência. O magistrado, diante questionamentos pertinentes feitos ao detido, obtém informações 
necessárias para cessar violações de direitos como prisões ilegais e práticas de maus-tratos.

\subsubsection{Contraditório}

A presença do Ministério Púbico, representando os interesses da sociedade, e a da Defensoria Pública, representando os interesses do detido, na Audiência de Custódia, asseguram o princípio do Contraditório.

\subsubsection{Prazo}

Conforme leciona Mauro Fonseca Andrade e Pablo Rodrigo Alflen sobre o tema abordado:

\footnotetext{
Para que os objetivos da Audiência de Custódia possam ser atingidos, a apresentação da pessoa ou detida não pode levar muito tempo. Só assim poder-seia evitar a incidência ou agravamento de possíveis agressões a quem for preso ou detido (...). Da mesma forma, evitar-se-ia o prolongamento de uma prisão que, já na origem ou ao longo de sua formalização, configurou-se ilegal ${ }^{142}$
}

Segundo os estudos já demonstrados anteriormente, o direito do preso de ser apresentado a uma autoridade competente o mais breve possível após o cerceamento de sua liberdade, é uma prática corriqueira no cenário internacional. Trata-se, portanto, de um princípio fundamental já inserido no ordenamento jurídico interno de muitos países. O que difere entre os países é a interpretação do termo "sem demora".

Pelo fato de não haver menção delimitativa quanto ao prazo de apresentação nos textos internacionais que instituem as diretrizes da Audiência de Custódia, cada país estabeleceu a sua interpretação legislativa quanto ao referido prazo.

${ }^{142}$ ANDRADE; ALFLEN, 2016, p. 66. 
Não há no código de processo penal nenhuma menção ao procedimento da Audiência de Custódia, quiçá quanto ao prazo para o encaminhamento do detido ao juiz.

$\mathrm{O}$ entendimento da jurisprudência da Corte Interamericana de Direitos Humanos é no sentido de que o prazo fixado em até 48 horas é razoável ${ }^{143}$.

A Resolução n 213/2015 do CNJ estabeleceu, administrativamente, que em até 24 horas da prisão em flagrante, deve ser realizada a Audiência de Custódia.

Questiona-se, porém, quanto a possibilidade de todas as regiões dos estados da Federação Brasileira possuírem condições e estruturas para se aterem a este prazo.

\subsubsection{Pessoa presa}

A liberdade, direito individual inviolável pilar que sustenta todo o Estado Democrático de Direito, é o bem jurídico basilar a ser tutelado pela a Audiência de Custodia. A apresentação pessoal do preso ao juiz, o mais breve possível após o cometimento de um delito, consiste no meio mais oportuno para salvaguardar a liberdade individual contra abusos e arbitrariedades do poder estatal.

Como já exaurido incessantemente (e propositalmente) no presente trabalho, a liberdade trata-se da regra e a prisão a exceção, de acordo com os padrões democráticos constitucionais brasileiros.

Partindo-se da premissa de que a prisão, escrita e fundamentada por uma autoridade competente é a regra, a prisão em flagrante, podendo ser

${ }^{143}$ ANDRADE; ALFLEN, 2016, p. 71. 
efetuada por qualquer um do povo, detém um caráter mais excepcional e peculiar.

A prisão em flagrante, conforme já explicitado no presente trabalho, por ser efetuada sem o crivo judicial prévio, a torna mais vulnerável a arbitrariedades e abusos do Estado.

Por esta razão, os atos administrativos emitidos pelos Tribunais dos Estados para regulamentar o procedimento da Audiência de Custodia, restringem a beneficiar com a apresentação imediata ao juiz, os detidos em flagrante.

A Resolução $n^{\circ} 213^{144}$, que regulamenta as Audiências de Custodias em âmbito nacional, amplia seu âmbito de atuação também as prisões cautelares e definitivas. Considerando que, nesses casos a prisão foi emanada pelo judiciário, não se questionaria a legalidade dessa segregação ou a aplicabilidade de medidas cautelares e sim, a integridade psíquica e física do conduzido/acusado de modo a fiscalizar possíveis ocorrências de violências praticadas pelos policias.

Nesta temática, complementa os juristas Mauro Fonseca Andrade e Pablo Rodrigo Alfen no que se refere o escopo da Audiência de Custodia do preso em decorrência de mandado:

(..) se poderá averiguar: a correta identidade do sujeito apresentado, de modo a confirmar que ele é realmente a pessoa contra quem foi expedida a ordem de prisão, e se ao se encontra extinta a punibilidade do sujeito ${ }^{145}$.

\footnotetext{
${ }^{144}$ Art. 13. A apresentação à autoridade judicial no prazo de 24 horas também será assegurada às pessoas presas em decorrência de cumprimento de mandados de prisão cautelar ou definitiva, aplicando-se, no que couber, os procedimentos previstos nesta Resolução. Parágrafo único. Todos os mandados de prisão deverão conter, expressamente, a determinação para que, no momento de seu cumprimento, a pessoa presa seja imediatamente apresentada à autoridade judicial que determinou a expedição da ordem de custódia ou, nos casos em que forem cumpridos fora da jurisdição do juiz processante, à autoridade judicial competente, conforme lei de organização judiciária local.

${ }_{145}$ ANDRADE; ALFLEN, 2016, p. 59.
} 
Contrariamente à resolução, as Audiências de Custódia somente alcançam os presos em flagrante na prática.

\subsubsection{Apresentação pessoal}

A Audiência de Custódia é a apresentação do detido, de forma mais célere possível, a autoridade competente após a prisão.

$\mathrm{O}$ código de processo penal brasileiro, em seu Art. $306 \S 1^{\circ} \mathrm{CPP}$ institui corretamente que o auto de prisão em flagrante deve ser remetido ao juiz em até 24 horas. Todavia falha ao normatizar que a comunicação da prisão deve ser feita por meio deste mero documento escrito.

É exatamente neste ponto em que consiste a principal característica da Audiência de Custódia: a apresentação pessoal do preso ao juiz. A humanização desta relação juiz-detido visa possibilitar que o magistrado realize uma entrevista com o preso reunindo todos os elementos possíveis para averiguar, primeiramente, (a) a legalidade da prisão, se viável a (b) liberdade provisória (acumulada ou não de alguma medida cautelar) e a (c) real proporcionalidade, adequação e necessidade da conversão da prisão em flagrante em prisão cautelar.

Por meio de um mero documento, torna-se obscura a análise do juiz quanto às condições pessoais do detido, minimizando assim as possibilidades da concessão da liberdade provisória sem ou com a imposição de medidas cautelares diversas do cárcere.

Dito isso em um raciocínio não muito árduo conclui-se que a ausência de elementos suficientes de convicção a respeito das condições pessoais do detido associada a cultura do encarceramento no qual a sociedade está inserida, é mais conveniente manter o indivíduo privado de sua liberdade em um cárcere do que libertá-lo e "colocar em risco a ordem pública". 
A Audiência de Custódia proporciona um aumento substancial das chances de averiguação das condições pessoais do preso para a decretação de medidas cautelares diversas da prisão. Além de reduzir o quadro de superlotação dos presídios, evita o contato do detido com presos mais perigosos e, obviamente, respeita os direitos fundamentais inerentes ao ser humano.

Não se trata de aumentar as chances da concessão da liberdade provisória do indivíduo e sim as chances de melhor se averiguar a possibilidade da aplicação de medidas que supram a necessidade de manutenção dos presos cautelares na cadeia, principalmente no que se diz respeito aos presos primários, de bons antecedentes e que cometeram seu primeiro crime considerado de baixo/médio potencial ofensivo.

Além de possível ruptura da cultura do encarceramento na qual não só o Poder Judiciário, mas toda a sociedade está inserida, a apresentação pessoal do preso é fundamental para que o juiz exerça a fiscalização da violência praticada contra os presos em sede policial.

Conforme leciona o jurista Rodrigo da Silva Brandalise:

Durante o interrogatório do preso em audiência de custodia, será ele perguntado sobre o tratamento recebido em todos os locais por onde passou antes da apresentação a audiência, assim como questionado sobre a ocorrência de tortura e maus-tratos, com adoção das providências cabíveis, como a realização de exame de corpo de delito para averiguação de sua materialidade ${ }^{146}$.

\subsubsection{Procedimento}

\subsubsection{Na teoria}

${ }^{146}$ PAIVA, 2016, p. 129. 
Segundo da Resolução $n^{\circ} 213$ proferida pelo CNJ, a Audiência de Custódia é, portanto, a apresentação ${ }^{147}$ do custodiado preso em flagrante ao juiz, obrigatoriamente no prazo de 24 horas após a prisão. A comunicação da prisão realizada por meio do auto de prisão em flagrante não supre ${ }^{148}$ a apresentação pessoal do detido ao juiz.

O deslocamento ${ }^{149}$ do preso em flagrante até ao local da audiência será responsabilidade da SEAP (Secretaria de Administração Penitenciaria ou da Secretaria de Segurança Pública), conforme a normatização de cada estado.

A Audiência de Custódia será presidida por um juiz sob o crivo do contraditório $^{150}$ na presença do Ministério Público e do defensor do detido, podendo ser representado pela Defensoria Pública ou por um advogado constituído. Será assegurado o atendimento ${ }^{151}$ prévio e em particular da defesa com o conduzido antes da audiência.

Na Audiência de Custódia, o juiz vai realizar uma entrevista com o conduzido, esclarecendo o que é152 essa audiência e instruindo o conduzido

\footnotetext{
${ }^{147}$ Art $1^{\circ}$ - Determinar que toda pessoa presa em flagrante delito, independentemente da motivação ou natureza do ato, seja obrigatoriamente apresentada, em até 24 horas da comunicação do flagrante, à autoridade judicial competente, e ouvida sobre as circunstâncias em que se realizou sua prisão ou apreensão.

${ }^{148}$ Art $1^{\circ}, \S 1^{\circ}$ - A comunicação da prisão em flagrante à autoridade judicial, que se dará por meio do encaminhamento do auto de prisão em flagrante, de acordo com as rotinas previstas em cada Estado da Federação, não supre a apresentação pessoal determinada no caput.

149 Art. $2^{\circ} \mathrm{O}$ deslocamento da pessoa presa em flagrante delito ao local da audiência e desse, eventualmente, para alguma unidade prisional específica, no caso de aplicação da prisão preventiva, será de responsabilidade da Secretaria de Administração Penitenciária ou da Secretaria de Segurança Pública, conforme os regramentos locais.

150 Art. $4^{\circ}$ A Audiência de Custódia será realizada na presença do Ministério Público e da Defensoria Pública, caso a pessoa detida não possua defensor constituído no momento da lavratura do flagrante.

${ }^{151}$ Art. $6^{\circ}$ Antes da apresentação da pessoa presa ao juiz, será assegurado seu atendimento prévio e reservado por advogado por ela constituído ou defensor público, sem a presença de agentes policiais, sendo esclarecidos por funcionário credenciado os motivos, fundamentos e ritos que versam a Audiência de Custódia.

${ }^{152}$ Art. $8^{\circ} \mathrm{Na}$ Audiência de Custódia, a autoridade judicial entrevistará a pessoa presa em flagrante, devendo:

I - esclarecer o que é a Audiência de Custódia, ressaltando as questões a serem analisadas pela autoridade judicial;
} 
acerca dos seus direitos constitucionais (como por exemplo o seu direito de permanecer em silencio ${ }^{153}$ durante a entrevista).

O juiz questionará o detido acerca das circunstâncias ${ }^{154}$ da prisão e se houve algum episódio de pratica de tortura ${ }^{155}$ e maus tratos em sede policial contra o mesmo, determinando inclusive que a materialidade da violência praticada seja obtida através da realização do exame de corpo de delito ${ }^{156}$.

A apresentação breve do preso ao juiz competente, como já dito anteriormente, possui três finalidades especificas: averiguação da ocorrência de tortura e maus-tratos praticados contra os detidos em sede policial, constatar prisões ilegais advindas das arbitrariedades e abusos do Estado e apurar as condições pessoais do detido para conceder a liberdade provisória com ou sem a acumulação de medidas cautelares.

Em suma, o objetivo da Audiência de Custodia não é acerca do mérito do fato criminoso que resultou a prisão e sim a averiguação da possibilidade de conceder ao réu, que possui condições favoráveis, o seu direito constitucional e democrático de aguardar a investigação criminal e o processo criminal em liberdade.

A regra é a liberdade e a prisão a exceção. O juiz deve decretar a prisão preventiva quando se tratar, o caso concreto, de uma hipótese incompatível com a concessão da liberdade provisória ao detido, com ou sem a imposição de alguma medida cautelar diversa do encarceramento. Somente quando o status libertatis do réu, no decorrer do processo ou

\footnotetext{
${ }^{153}$ Art. $8^{\circ}(\ldots)$

III - dar ciência sobre seu direito de permanecer em silêncio;

${ }^{154}$ Art. $8^{\circ}(\ldots)$

V - indagar sobre as circunstâncias de sua prisão ou apreensão;

${ }^{155}$ Art. $8^{\circ}(\ldots)$

VI - perguntar sobre o tratamento recebido em todos os locais por onde passou antes da apresentação à audiência, questionando sobre a ocorrência de tortura e maus tratos e adotando as providências cabíveis;

${ }^{156}$ Art. $8^{\circ}(\ldots)$

VII - verificar se houve a realização de exame de corpo de delito, determinando sua realização nos casos em que:

c) a alegação de tortura e maus tratos referir-se a momento posterior ao exame realizado;
} 
durante a investigação criminal, colocar em risco a ordem pública, ordem econômica, instrução criminal ou a futura aplicação da lei penal, deverá então ser aplicada a prisão cautelar.

Por este motivo, o juiz não deve interrogar o réu com o fim de produzir provas antecipadas para a investigação criminal ou a futura ação penal. Deve o juiz indagar, por exemplo, se o conduzido possui residência fixa, trabalho fixo, dependentes menores pois estas condições pessoais travam o perfil de um indivíduo que não irá evadir-se de modo a impossibilitar, futuramente, a aplicação da lei penal. Questionar, por exemplo, se o conduzido é primário e possui bons antecedentes pois, sendo o suposto crime praticado por ele de baixo/médio potencial ofensivo (sem o uso de violência) a concessão do seu status libertatis, não ameaçaria a ordem pública. Ressalta-se ainda que nessas condições abordadas, o réu dificilmente seria condenado a uma pena de reclusão, não havendo proporcionalidade, por conseguinte, em manter o detido preso cautelarmente durante a investigação ou o processo criminal.

Após essa entrevista realizada pelo juiz, será concedida a palavra para o representante do Ministério Público e da defesa (advogado constituído ou Defensoria Pública) para realizar perguntas ${ }^{157}$ compatíveis com a finalidade da Audiência de Custódia, qual seja a verificação da viabilidade do custodiado responder ao processo em liberdade, com/sem a acumulação de medidas cautelares ou, se necessário, adequado e proporcional, a convolação da prisão em flagrante em prisão preventiva. $O$ magistrado deverá indeferir, portanto, questionamentos que visam

\footnotetext{
${ }^{157}$ Art. $8^{\circ}-(\ldots)$

$\S 1^{\circ}$ Após a oitiva da pessoa presa em flagrante delito, o juiz deferirá ao Ministério Público e à defesa técnica, nesta ordem, reperguntas compatíveis com a natureza do ato, devendo indeferir as perguntas relativas ao mérito dos fatos que possam constituir eventual imputação, permitindo-lhes, em seguida, requerer:

I - o relaxamento da prisão em flagrante;

II - a concessão da liberdade provisória sem ou com aplicação de medida cautelar diversa da prisão;

III - a decretação de prisão preventiva;

IV - a adoção de outras medidas necessárias à preservação de direitos da pessoa presa.
} 
exclusivamente indagar o conduzido sobre o mérito do fato, como por exemplo: "você cometeu o crime?".

Ressalta-se, mais uma vez, que o objetivo da Audiência de Custódia não é a produção de provas para a investigação e para embasar a futura ação penal e sim, a averiguação mais detalhada acerca da possibilidade da concessão do status libertatis do conduzido durante a investigação criminal e o decorrer do processo.

Após este procedimento, o juiz deverá deliberar acerca do relaxamento da prisão, da concessão da liberdade provisória (com/sem a acumulação de medidas cautelares ${ }^{158}$ distintas da prisão), decretação da prisão preventiva ou adoção de outras medidas necessárias a preservação do direito da pessoa presa (como no caso em que o detido declare ter sido vítima de violências em sede policial, o juiz determinará ${ }^{159}$ o registo dessas informações e encaminhamento do detido para o atendimento médico e psicológico).

O termo da Audiência de Custódia será apensado ${ }^{160}$ ao inquérito ou a ação penal.

\footnotetext{
158 Art. 10. A aplicação da medida cautelar diversa da prisão prevista no art. 319, inciso IX, do Código de Processo Penal, será excepcional e determinada apenas quando demonstrada a impossibilidade de concessão da liberdade provisória sem cautelar ou de aplicação de outra medida cautelar menos gravosa, sujeitando-se à reavaliação periódica quanto à necessidade e adequação de sua manutenção, sendo destinada exclusivamente a pessoas presas em flagrante delito por crimes dolosos puníveis com pena privativa de liberdade máxima superior a 4 (quatro) anos ou condenadas por outro crime doloso, em sentença transitada em julgado, ressalvado o disposto no inciso I do caput do art. 64 do Código Penal, bem como pessoas em cumprimento de medidas protetivas de urgência acusadas por crimes que envolvam violência doméstica e familiar contra a mulher, criança, adolescente, idoso, enfermo ou pessoa com deficiência, quando não couber outra medida menos gravosa.

Parágrafo único. Por abranger dados que pressupõem sigilo, a utilização de informações coletadas durante a monitoração eletrônica de pessoas dependerá de autorização judicial, em atenção ao art. $5^{\circ}$, XII, da Constituição Federal.

${ }^{159}$ Art. 11. Havendo declaração da pessoa presa em flagrante delito de que foi vítima de tortura e maus tratos ou entendimento da autoridade judicial de que há indícios da prática de tortura, será determinado o registro das informações, adotadas as providências cabíveis para a investigação da denúncia e preservação da segurança física e psicológica da vítima, que será encaminhada para atendimento médico e psicossocial especializado.

${ }^{160}$ Art. 12. O termo da Audiência de Custódia será apensado ao inquérito ou à ação penal.
} 
A aplicação de medidas cautelares ${ }^{161}$ distintas da prisão será decretada pelo juiz da Audiência de Custódia e o seu acompanhamento será realizado regularmente pelo juízo a qual for distribuído o APF, após a realização da audiência.

\subsubsection{Na prática}

O Rio de Janeiro foi o vigésimo estado da Federação a aderir ao Projeto da Audiência de Custódia de iniciativa do CNJ. O lançamento ocorreu no dia 18 de setembro de 2015 e através da Resolução TJ/OE N 29, publicada em 26/8/2015 (alterada pela Resolução TJ/OE/RJ n 32/2015, de 09/09/2015), o Tribunal de Justiça do Rio de Janeiro disciplinou o procedimento da Audiência de Custódia a ser adotado no Estado e criou a Central de Audiência de Custódia.

\footnotetext{
${ }^{161}$ Art. $9^{\circ}$ A aplicação de medidas cautelares diversas da prisão previstas no art. 319 do CPP deverá compreender a avaliação da real adequação e necessidade das medidas, com estipulação de prazos para seu cumprimento e para a reavaliação de sua manutenção, observando se o Protocolo I desta Resolução.

$\S 1^{\circ} \mathrm{O}$ acompanhamento das medidas cautelares diversas da prisão determinadas judicialmente ficará a cargo dos serviços de acompanhamento de alternativas penais, denominados Centrais Integradas de Alternativas Penais, estruturados preferencialmente no âmbito do Poder Executivo estadual, contando com equipes multidisciplinares, responsáveis, ainda, pela realização dos encaminhamentos necessários à Rede de Atenção à Saúde do Sistema Único de Saúde (SUS) e à rede de assistência social do Sistema Único de Assistência Social (SUAS), bem como a outras políticas e programas ofertados pelo Poder Público, sendo os resultados do atendimento e do acompanhamento comunicados regularmente ao juízo ao qual for distribuído o auto de prisão em flagrante após a realização da Audiência de Custódia.

$\S 2^{\circ}$ Identificadas demandas abrangidas por políticas de proteção ou de inclusão social implementadas pelo Poder Público, caberá ao juiz encaminhar a pessoa presa em flagrante delito ao serviço de acompanhamento de alternativas penais, ao qual cabe a articulação com a rede de proteção social e a identificação das políticas e dos programas adequados a cada caso ou, nas Comarcas em que inexistirem serviços de acompanhamento de alternativas penais, indicar o encaminhamento direto às políticas de proteção ou inclusão social existentes, sensibilizando a pessoa presa em flagrante delito para o comparecimento de forma não obrigatória.

$\S 3^{\circ} \mathrm{O}$ juiz deve buscar garantir às pessoas presas em flagrante delito o direito à atenção médica $\mathrm{e}$ psicossocial eventualmente necessária, resguardada a natureza voluntária desses serviços, a partir do encaminhamento ao serviço de acompanhamento de alternativas penais, não sendo cabível a aplicação de medidas cautelares para tratamento ou internação compulsória de pessoas autuadas em flagrante que apresentem quadro de transtorno mental ou de dependência química, em desconformidade com o previsto no art. $4^{\circ}$ da Lei 10.216, de 6 de abril de 2001, e no art. 319, inciso VII, do CPP.
} 
A Resolução $n^{\circ} 29$ emanada pelo TJ/RJ não previa um prazo especifico $^{162}$ para que o detido fosse apresentado ao magistrado, somente condicionava a Audiência de Custódia, ao preso em flagrante e não obrigava $^{163}$ a presença do Ministério Público e do defensor/advogado na audiência.

Em $1^{\circ}$ de fevereiro de 2016, entrou em vigor a Resolução n 213 emanada pelo CNJ, que estabeleceu o prazo de 90 dias para que os Tribunais de Justiça e os Tribunais Regionais Federais ${ }^{164}$ implantassem a Audiência de Custódia conforme o disposto na referida Resolução.

162 Art. $2^{\circ}$ - Toda pessoa presa em flagrante delito será apresentada, sem demora, ao juiz competente, a fim de realizar se Audiência de Custódia.

Parágrafo único - Por decisão judicial, devidamente fundamentada, será dispensada a apresentação do preso quando forem reconhecidas circunstâncias pessoais que a inviabilizem.

163 Art. $6^{\circ}$ - Aberta a audiência, o preso será ouvido a respeito das circunstâncias da prisão e suas condições pessoais, manifestando se, em seguida, o MP e defesa, se presentes ao ato.

Parágrafo único - As declarações do preso colhidas, preferencialmente, por meio digital, serão lacradas e mantidas em separado.

${ }^{164}$ A Resolução TRF2-RSP-2015/00031 de 18 de dezembro de 2015 regulamenta o procedimento da Audiência de Custódia no âmbito da jurisdição da Seção - Judiciária do Rio de Janeiro e da Seção Judiciária do Espírito Santo:

Seção Judiciária do Rio de Janeiro.

Art. $7^{\circ}$. Fica criada na Sede da Seção Judiciária do Rio de Janeiro a Central de Audiências de Custódia - CAC -, que terá competência para a análise de autos de prisão em flagrante e para a realização das audiências de custódia, concernentes a fatos de competência das Varas Federais da Seção Judiciária da Capital do Estado.

Parágrafo único. As audiências de custódia nas subseções judiciárias do Rio de Janeiro serão realizadas pelas Varas Federais respectivamente competentes para a apreciação da prisão em flagrante.

Art. $8^{\circ}$. As atividades inerentes à Central de Audiências de Custódia serão realizadas pelas Varas Federais Criminais da Capital, que atuarão em regime de rodízio, com escala de 15 dias, e sem prejuízo do funcionamento regular da respectiva unidade judiciária.

$\S 1^{\circ}$. A Central de Audiências de Custódia funcionará na respectiva vara, conforme rodízio, contando com a estrutura física e de pessoal desta, enquanto não disponibilizados, pela Direção do Foro, os recursos necessários para instalação própria.

$\S 2^{\circ}$. A atuação do magistrado na Central de Audiências de Custódia dar-se- á sem prejuízo do exercício de sua jurisdição na Vara Federal em que tiver competência.

$\S 3^{\circ}$. A escala de rodízio será elaborada e divulgada, anualmente, pela Corregedoria-Regional da Justiça Federal da $2^{\text {a }}$ Região, observada, preferencialmente, a ordem numérica crescente das Varas Federais Criminais.

$\S 4^{\circ}$. Caberá à Corregedoria, quando da comunicação da escala anual, solicitar a designação de membros do Ministério Público Federal e da Defensoria Pública da União para atuarem na Central de Audiências de Custódia.

$\S 5^{\circ}$. A Direção do Foro encaminhará à Superintendência Regional da Polícia Federal no Rio de Janeiro e à Secretaria de Estado de Segurança Pública do Estado do Rio de Janeiro - SESEG -, a escala de rodízio das unidades judiciárias que atuarão como Central de Audiências de Custódia. Art. $9^{\circ}$. Durante o expediente forense normal, definido nos termos do parágrafo $2^{\circ}$, do art. 117 , do Provimento n. 11, de 04.04.2011 (Consolidação de Normas da Corregedoria-Regional da Justiça 
Entre as disposições previstas pela Resolução do CNJ divergentes da Resolução emanada pelo TJ/RJ, tem-se a determinação do prazo máximo de 24 horas para que ocorra a apresentação do detido a autoridade competente, a presença obrigatória do MP e da Defensoria (ou advogado constituído) na audiência e a ampliação do instituto a todas as pessoas presas, não só as presas em flagrante, mas em decorrência de mandado de prisão cautelar e definitivo.

Na prática ${ }^{165}$ vislumbra-se que o procedimento adotado na realização das Audiências de Custódias na Comarca da Capital, adere conjuntamente às diretrizes previstas tanto na Resolução $\mathrm{n}^{\circ} 213$ do CNJ quanto na Resolução n²9 emitida pelo TJ/RJ.

Atualmente a Audiência de Custódia no Estado do Rio de Janeiro é realizada na sala 907 do TJ/RJ e são feitas cerca de 30 a 40 audiências por dia.

Somente quem é preso no Município do Rio de Janeiro tem direito à realização da Audiência de Custódia. O TJ/RJ não cumpriu o prazo previsto na Resolução do CNJ de tornar as Audiências de Custódia uma realidade em todas as comarcas do estado, e infelizmente não há previsão concreta para que se inicie a interiorização do projeto. Deve-se considerar que a

Federal), os autos da Comunicação de Prisão em Flagrante serão distribuídos à Central de Audiências de Custódia.

Parágrafo único. Enquanto não implantado o peticionamento eletrônico, a Seção de Distribuição Criminal fará o registro, a autuação, a digitalização dos autos da Comunicação de Prisão em Flagrante e, em qualquer caso, os encaminhará, imediatamente, à Vara Federal Criminal que estiver responsável pela Central de Audiências de Custódia.

Art. 10. Recebidos os autos da Comunicação da Prisão em Flagrante na Central de Audiências de Custódia, será providenciada a juntada da Folha de Antecedentes Criminais, extraída da base de dados do IFP/SSP/RJ, e das certidões de antecedentes criminais dos arquivos do SINIC e do INFOSEG, caso já não instruam os referidos autos.

Art. 11. A autoridade policial, logo após a realização do exame de perícia de integridade física do preso pelo Instituto Médico Legal, o encaminhará, imediatamente, ao Juízo que estiver atuando como Central de Audiências de Custódia, juntamente com o laudo pericial oficial.

Art. 12. Terminada a Audiência de Custódia, os autos serão remetidos à Seção de Distribuição Criminal -SEDCR - para imediata distribuição a uma das Varas Federais Criminais da Seção Judiciária da Capital do Estado.

${ }^{165}$ Todas as informações descritas neste subcapítulo foram adquiridas através de uma entrevista exclusiva com os operadores de justiça e com a equipe multidisciplinar que atuam na Central da Audiência de Custódia, localizada no Tribunal de Justiça do Estado do Rio de Janeiro. 
realidade das comarcas situadas em locais mais longínquos da capital, apresentam restrições quanto ao número de servidores públicos, policiais, magistrados, fatores que dificultam a difusão do instituto por todo o Rio.

Existem 5 juízes e 1 juíza coordenadora atuando na Central da Audiência de Custódia, durante o prazo de 4 meses (que podem ser renovados por mais 4 meses). Após este período, abre-se um edital e um novo rodízio de juízes é feito. O juiz que realiza a Audiência de Custódia é diferente do juiz que presidirá a AIJ.

No interior, alguns (poucos) juízes realizam Audiências de Custódia na própria vara. Acaba por coincidir na figura do mesmo magistrado o juiz que preside ambas as Audiências (de custódia e de instrução e julgamento) porém, diante a inercia do TJ/RJ quanto a expansão do projeto, esta acaba sendo a única alternativa para o cumprimento da Resolução do CNJ e dos tratados internacionais ratificados pelo Brasil.

Hoje, todas as delegacias do Município do Rio de Janeiro são afetadas e fazem parte do projeto das Audiência de Custódia.

O preso em flagrante é conduzido a presença do juiz sem demora (em regra, o TJ/RJ está cumprindo o prazo de 24 horas) para que, através de uma entrevista pessoal, o magistrado possa obter mais elementos de convicção para deliberar acerca da legalidade da prisão, manutenção do cárcere ou da concessão da liberdade provisória (com ou sem a imposição de medidas cautelares) além de constatar a ocorrência de possíveis maustratos contra o detido em sede policial.

$\mathrm{O}$ TJ/RJ construiu duas salas de audiência, uma sala para uma equipe médica e uma sala para a equipe psicossocial especializada. Os presos em flagrante, quando chegam ao TJ/RJ, primeiramente passam por um atendimento médico (alguns detidos apresentam ferimentos oriundos da perseguição policial, da própria população ou são vítimas de maus-tratos 
praticados pelos agentes do estado no ato da prisão). Depois, são atendidos pela Defensoria Pública (existem cabines individuais na carceragem do Fórum onde ocorrem os atendimentos) e em seguida são conduzidos para a apresentação pessoal com o juiz. Após a Audiência de Custódia, os detidos que tiveram a liberdade provisória concedida, são encaminhados para a equipe técnica/psicossocial/multidisciplinar onde são avaliados por uma psicóloga e uma assistente social.

O primeiro procedimento realizado pelo juiz na entrevista com o detido é o questionamento acerca da sua qualificação. Pergunta-se: nome completo, nome dos pais, data de nascimento, estado civil, local em que reside, com quem reside, se possui filhos menores e se alguns deles possui deficiência, grau de escolaridade, se possui ocupação profissional lícita, onde exerce seu trabalho, qual a sua renda mensal. Indaga-se também se o detido sofreu alguma agressão por parte dos policias no ato da prisão e se é usuário de drogas/bebida alcoólica. Caso o detido afirme ter sido vítima de alguma violência no ato da prisão, o juiz questiona se há marcas aparentes no corpo da vítima e o nome do policial que o agrediu. Após a entrevista, o detido violentado é encaminhado para o IML para a materialização da alegação dos maus-tratos sofridos.

Após a oitiva do custodiado, o Ministério Público profere o seu parecer requerendo o relaxamento da prisão em flagrante, a concessão da liberdade provisória (com ou sem a imposição de cautelares) ou a decretação da prisão preventiva. Em seguida, é concedida a palavra ao Defensor Público (ou advogado) em defesa do detido.

Assegurado o contraditório, o juiz prefere a decisão.

A audiência é registrada em mídia e a ata futuramente será anexada aos autos do processo. Esta ata contém um breve resumo sobre a audiência, o veredito do juiz quanto a legalidade, concessão da liberdade provisória 
(com ou sem a imposição de medida cautelar) ou manutenção da prisão e a constatação de eventuais indícios de tortura.

Caso o juiz decida pela liberdade provisória do preso em flagrante (com ou sem a imposição de medida cautelar), ele será encaminhado para o atendimento com a equipe técnica/psicossocial/multidisciplinar da Central da Audiência de Custódia. Neste "acolhimento social”, a psicóloga e a assistente social, através de uma "entrevista" informal acerca dos motivos que levaram o detido a cometer o suposto crime, avaliam qual a medida necessária a ser tomada para evitar que o indivíduo retorne a delinquir. Através desta abordagem social, os presos (que muitas vezes não possuem documentos, se encontram desempregados, são dependentes químicos, moradores de rua) são encaminhados a uma rede de proteção, tratamento e assistência social do Município e do estado, como por exemplo o CREAS $^{166}$. Ressalta-se que os detidos submetidos a assistência multidisciplinar possuem uma abordagem social diferenciada no estado do Rio de Janeiro pois além de serem encaminhados para tratamento especializado conforme suas necessidades, recebem amparo psicológico, um vale-transporte (FETRANSPOR) para voltar para a casa e vestimentas (blusa e chinelo) caso necessitem.

Após esta abordagem, os presos que foram beneficiados com a liberdade provisória são liberados desde logo no próprio Fórum. Na prática, observa-se que a liberdade provisória é concedida com a imposição das medidas cautelares de comparecimento periódico em juízo e a proibição de acesso a determinados lugares. Já, nos casos em que seja decretada a prisão preventiva pelo juiz, será expedido o mandado de prisão preventiva e eles retornam a carceragem sem o atendimento psicossocial.

Faz-se mister ressaltar o fato de que as Audiências de Custódias no TJ/RJ não são públicas para os familiares, sendo somente autorizada a

${ }^{166}$ Centro de Referência Especializado de Assistência Social. 
presença de estudantes e acadêmicos de Direito para assisti-las com a permissão do juiz que preside a audiência.

As Audiências de Custódia no TJ/RJ são realizadas, na prática, de segunda a sexta, das $13 \mathrm{~h}$ às $17 \mathrm{~h}$ e o preso em flagrante delito deve ser apresentado ao magistrado dentro do período máximo 24 horas. Acerca da temática faz-se mister nos atermos a questão de que as prisões efetuadas após às $17 \mathrm{~h}$ na sexta-feira, sábado ou domingo (ou feriados) são comunicadas, através do APF, ao Plantão Judiciário. Se, o juiz plantonista deliberar acerca da manutenção da prisão, o preso será apresentado a um juiz, através da Audiência de Custódia, e a decisão será reanalisada na segunda feira. Caso o juiz plantonista conceda o status libertatis do detido, não será marcada Audiência de Custódia.

Os custodiados que são presos em flagrante após as $17 \mathrm{~h}$ nos dias em que não há Audiência de Custódia (sexta-feira, sábado, domingo e feriados) são encaminhados para uma carceragem especifica em Bangu (não possuem contato com outros presos), onde aguardam até segunda-feira (ou o próximo dia útil) para a realização audiência ficando sob responsabilidade da SEAP (Secretaria de Estado de Administração Penitenciária). Já os custodiados que são presos durante a semana após as $17 \mathrm{~h}$ aguardam a realização da próxima Audiência de Custódia no dia seguinte (útil) nas próprias carceragens da delegacia ou na Cidade da Polícia.

O Tribunal de Justiça do Estado do Rio de Janeiro, divulgou ${ }^{167}$ que 5.105 Audiências de Custódias foram realizadas no estado entre o período de 18/08/2015 a 22/07/2016. Deste total, 59.69\% (3.047) resultaram na conversão da prisão em flagrante em prisão preventiva; 40.31\% (2.058) deliberaram favoravelmente a concessão da liberdade provisória aos detidos; $58.69 \%$ (2.996) dos presos em flagrante foram encaminhados para

\footnotetext{
${ }^{167}$ CNJ. Dados Estatísticos. Disponível em: <http://www.cnj.jus.br/sistema-carcerario-e-execucaopenal/audiencia-de-custodia/mapa-da-implantacao-da-audiencia-de-custodia-no-brasil $>$ Acesso em: 2 set. 2016.
} 
o serviço social (à rede de proteção e assistência social do município e do estado); e em 2\% das audiências (101), os detidos discorreram sobre a pratica de violência realizada pelos agentes do Estado no ato da prisão.

Em suma, na prática não só do Rio de Janeiro mas em todos os Estados da Federação, observa-se que a Resolução no 213 do CNJ é uma orientação/instrução para nortear os operadores da Audiência de Custódia e não um regramento obrigatório.

Nota-se com o "projeto inicial" da Capital localizado no Tribunal de Justiça do Estado do Rio de Janeiro, que a presença do Ministério Público e da Defensoria Pública na Audiência de Custódia é obrigatória para assegurar o Princípio do Contraditório. Além disso, o projeto da Capital demonstra o seu viés social e humanitário com os presos ao disponibilizar uma assistência psicossocial, através da equipe multidisciplinar na Central da Audiência de Custódia (nas próprias dependências do TJ/RJ) que, a partir da abordagem feita através de uma "entrevista social" com o detido, encaminha-o para uma rede de tratamento específico visando a sua reinserção na sociedade e evitando a sua reincidência. Observa-se ainda que somente beneficia os presos em flagrante e a regra é que a Audiência de Custódia seja efetuada no prazo máximo de 24 horas. Trata-se, porém, de um "prazo impróprio" pois nem sempre é possível obedece-lo (prisões efetuadas após as $17 \mathrm{~h}$ na sexta, sábado, domingo ou feriados) e o seu descumprimento não condicionar o caráter ilegal da prisão preventiva convertida através do APF.

O Projeto da Audiência de Custódia no Estado do Rio de Janeiro precisa ser aperfeiçoado em muitos pontos principalmente no tocante a realização diária das audiências (inclusive nos finais de semana e feriados) e na expansão do projeto para todas as regiões Estado, não só na Capital. Nas Comarcas em que não são realizadas Audiências de Custódias os Defensores Públicos lutam através de HC e Reclamações no Supremo para 
exigir que estas sejam realizadas em casos específicos, até o momento em que Tribunal estenda esse direito a todos os cidadãos do Rio de Janeiro, independente de espaço territorial.

Apesar do icônico acordão proferido em 04/01/2016 pela Sexta Câmara Criminal do TJ/RJ, em sede de HC (HC - 006491046.2014.8.19.0000) $)^{168}$, ter concedido a ordem de relaxamento da prisão preventiva uma vez que esta foi decretada sem a realização da Audiência de Custódia, este não é o entendimento majoritário do Tribunal.

A jurisprudência do TJ/RJ mais recente consolida o entendimento de que a impossibilidade da realização da Audiência de Custódia não é suficiente para gerar a nulidade da prisão preventiva convertida a partir do flagrante. A justificava utilizada é a de que apesar da orientação do CNJ, dos tratados internacionais e da própria resolução do TJ/RJ que disciplina o procedimento da Audiência de Custódia, a comunicação da prisão em flagrante ao juiz pelo APF está em consonância com a Constituição (Art. 5º, LXII) e com o código de processo penal (Art. 306\$1 $1^{\circ}$ ).

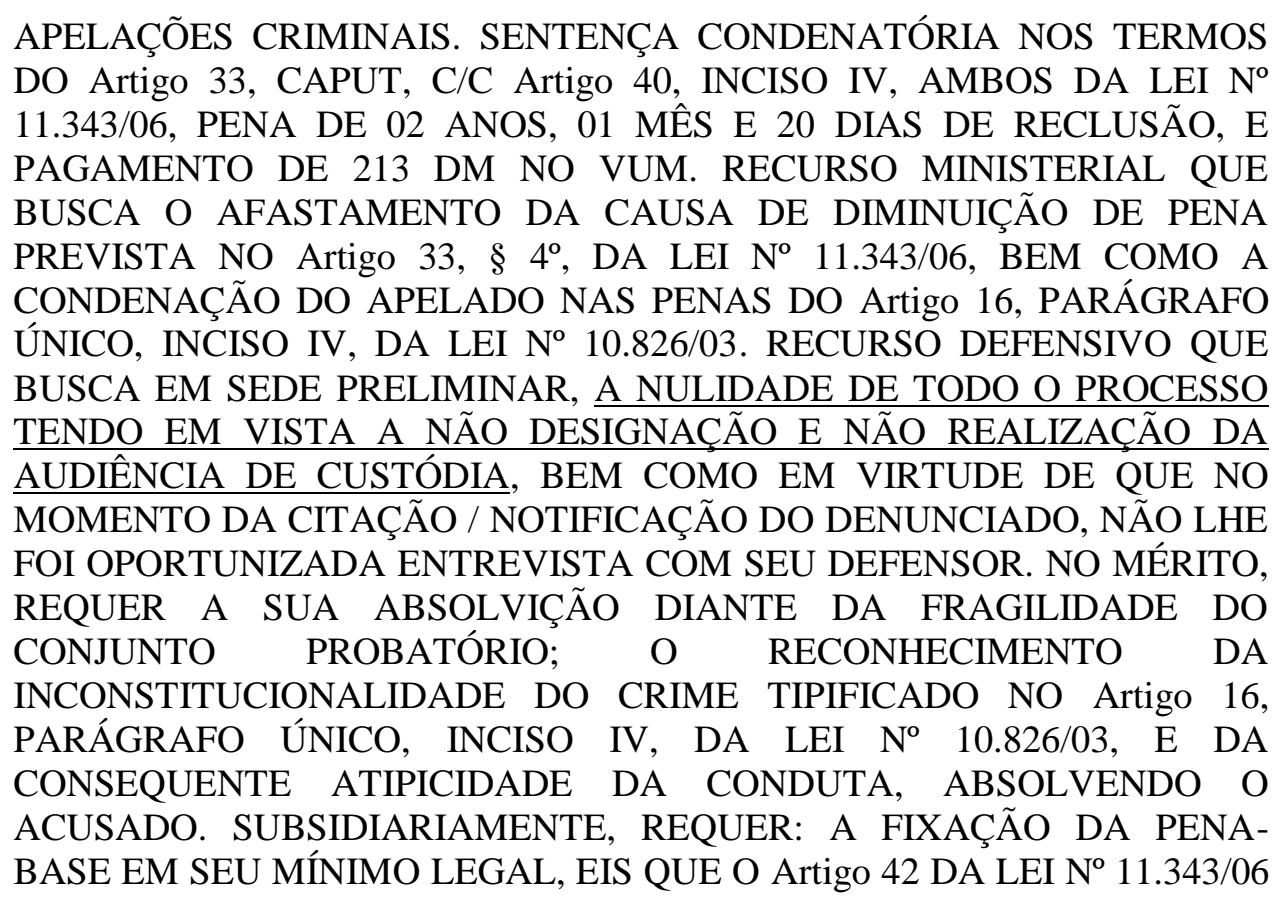

168 TJ/RJ, HC n. 0064910-46.2014.8.19.0001, Rel. Luiz Noronha Dantas, Sexta Câmara Criminal, Rio de Janeiro, 25 jan. 2016. 
AINDA NÃO FOI REGULAMENTADO; A SUBSTITUIÇÃO DA PENA CORPORAL POR RESTRITIVA DE DIREITOS; A APLICAÇÃO DO REGIME ABERTO; A CONCESSÃO DO SURSIS E DA GRATUIDADE DE JUSTIÇA. RECURSO MINISTERIAL AO QUAL SE DÁ PARCIAL PROVIMENTO. RECURSO DEFENSIVO A QUE SE NEGA PROVIMENTO, REJEITANDO-SE AS PRELIMINARES SUSCITADAS. 1. PRELIMINARES que se rejeitam. Quanto ao alegado prejuízo oriundo da não designação e não realização da Audiência de Custódia, verifica-se dos autos que a prisão em flagrante foi devidamente analisada pelo magistrado de piso, que teve por convertê-la em prisão preventiva, sendo certo que no Estado do Rio de Janeiro, através da Resolução TJ/OE N $\mathrm{N}^{\circ} 29$, publicada em 26/8/2015, com as alterações advindas pela Resolução TJ/OE/RJ n ${ }^{\circ}$ 32/2015, de 09/09/2015, ficou disciplinado que: "Toda pessoa presa em flagrante delito será apresentada, sem demora, ao juiz competente, a fim de realizar se Audiência de Custódia ". 2. No entanto, referida Resolução criou o sistema de Audiência de Custódia na Comarca da Capital, estando em vias de expandi-lo para todo o Estado, pelo que, não se encontra abrangida a comarca originária do presente feito. 3. Outrossim, quanto ao reconhecimento da nulidade do feito em razão da ausência de Entrevista Prévia com seu Defensor, violando-se assim o princípio da ampla defesa, tem-se por se ressaltar que referido pleito não possui amparo legal na medida em que, como se depreende do artigo $185, \S 5^{\circ}$, do CPP, ao acusado é garantido o direito de entrevistar-se com seu Defensor, pessoalmente, antes da realização do seu Interrogatório, nada aduzindo referido dispositivo quanto á entrevista em momento anterior à apresentação da defesa prévia 4. MÉRITO. Autoria e materialidade bem definidas em relação ao crime de tráfico de entorpecentes. Aplicação da súmula $\mathrm{n}^{\circ} 70$ do Egrégio TJ/RJ. Depoimentos prestados pelas testemunhas de acusação que se mostram harmônicos com as demais provas dos autos. 5. Manutenção da exasperação da pena-base em razão da elevada quantidade de droga apreendida, assim como de sua qualidade, tendo em vista o permissivo legal aposto no artigo 42 da Lei de Drogas, restando inalterada a fração de 1/10 aplicada em sede monocrática. 6. Quanto ao pleito defensivo referente à absolvição do delito de porte de arma de fogo, tem-se que o mesmo restou prejudicado, eis que em sentença o magistrado de piso teve por aplicar a causa de aumento de pena prevista no artigo 40, inciso IV, da Lei $\mathrm{n}^{\circ} 11.343 / 06$, absolvendo o acusado da imputação relativa ao artigo 16, parágrafo único, inciso IV, da Lei $n^{\circ} 10.826 / 03$. 7. Manutenção da aplicação do princípio da consunção quanto ao delito inserto no artigo 16 da Lei $n^{\circ} 10.826 / 03$, para que o mesmo seja absorvido pelo crime de Tráfico de Entorpecentes, procedendo-se à desclassificação do delito tipificado para fazer incidir a causa de aumento de pena prevista no inciso IV do artigo 40 da Lei $\mathrm{n}^{\circ} 11.343 / 06$, restando prejudicado o pleito ministerial. 8. Acolhimento do pleito ministerial para afastamento da minorante inserta no artigo $33, \S 4^{\circ}$, da Lei $n^{\circ} 11.343 / 06$, eis que dos depoimentos prestados pelas testemunhas de acusação, verifica-se que o acusado Perlison foi detido com uma arma na mão, de posse ainda de 32 (trinta e duas) munições, enquanto mexia em uma mochila que continha material entorpecente, no quantitativo de 180,9g (cento e oitenta gramas e nove decigramas) da substância conhecida como Cocaína, acompanhado de um terceiro elemento que conseguiu se evadir quando da ação policial, pelo que se vislumbra que o mesmo não faz jus à minorante prevista no artigo $33, \S 4^{\circ}$, da Lei $n^{\circ} 11.343 / 06$. 9. Em razão do acima exposto, verifica-se que o acusado Perlison não atende aos requisitos do $\S$ $4^{\circ}$ do artigo 33 da Lei $n^{\circ} 11.343 / 06$, diante da sua dedicação à atividade criminosa, restando assim, prejudicados os pleitos defensivos de substituição da pena corporal por restritiva de direitos; concessão do regime aberto para cumprimento de pena, e aplicação do sursis. 10. Pleito de isenção de custas que deve ser analisado pelo Juízo da Execução, conforme Art. 804 do CPP e Súm. nº 
74 deste E. TJ/RJ. 11. Pena final que restou estabelecida no patamar de 06 anos e 05 meses, e pagamento de 641 DM no VUM. 12. Quanto ao regime inicial para cumprimento de pena, tem-se por se aplicar o fechado, eis que amoldo minha convicção no sentido de que o mesmo é o que melhor se impõe ao caso concreto, observando-se todo o contexto histórico e comprobatório do caso ${ }^{169}$.

Habeas corpus. Conversão de APF em preventiva. Imputação do delito de tráfico de drogas com majorante do envolvimento de menor (Arts. $33 \mathrm{c} / \mathrm{c} 40$, VI, ambos da Lei 11.343/06). Writ que questiona a legalidade da prisão, face a não realização de Audiência de Custódia, bem como a fundamentação do decreto prisional e o binômio necessidade-conveniência da custódia cautelar. Feito redistribuído, na forma regimental, pela superveniência de férias da Desembargadora-Relatora originária, por decisão da $2^{\text {a }}$ Vice-Presidência da Corte, a pedido do Impetrante. Mérito que se resolve parcialmente em favor do Paciente. Primeiro questionamento, recaindo sobre o exame da legalidade da situação de flagrância, que se apresenta prejudicado face à regular conversão do APF em preventiva - precedente do STJ. Conteúdo da postulação defensiva que, de qualquer modo, se mostra inviável. Tratado que, internalizado no Direito Pátrio antes da EC 45/04, ostenta a natureza de regra supralegal, mas tem interpretação subordinada aos princípios constitucionais vigentes, por intermédio dos quais, ao lado da proteção dos direitos fundamentais (individuais e coletivos), se tutela também, proporcionalmente, os deveres fundamentais do Estado e da sociedade, depurando-se, a partir dessa ponderação, o necessário equilíbrio que se almeja na vida em sociedade. Projeção dos postulados da duração razoável do processo (CF, Art. $5^{\circ}$, LXXVIII) e da efetividade de proteção da segurança pública (CF, Art. 144) que reforçam a necessidade de prévia regulamentação do referido Tratado, sob o signo da responsabilidade e razoabilidade interpretativas. Pacto que, a despeito da proeminência normativa, ostenta eficácia limitada e cunho programático quanto à extensão e alcance materiais dos seus preceitos, a depender de regulamento integrador futuro, que preveja, pormenorizadamente, a forma, o exato momento e o procedimento específico de sua materialização prática. "Audiência de Custódia " que carece, assim, de regulamentação legal específica, tanto que ainda é objeto de projeto de lei no âmbito do Parlamento Federal, a despeito de certos experimentos pioneiros por parte do CNJ e TJERJ (Resolução n. 29/2015), cuja eventual inaplicabilidade não é suficiente para gerar consequências nulificadoras automáticas. Código de Processo Penal que não prevê esse tipo de providência, limitando-se a preceituar que, "em até 24 horas após a realização da prisão, será encaminhado ao juiz competente o auto de prisão em flagrante e, caso o autuado não informe o nome de seu advogado, cópia integral para a Defensoria Pública" (\$ 10 do Art. 306). Exame de legalidade preambular do flagrante feito pelo Juiz na sequência, segundo o preceptivo do Art. 310 do CPP, suficiente a depurar a regularidade e a conveniência da custódia imposta, independentemente de qualquer audiência, já que ressonante nos incisos LXXVIII, XXXV, LIV, LXI, LXII, LXV e LXVI, do Art. $5^{\circ}$, da Lex Legum. Precedentes jurisprudenciais que sedimentam a ausência de regularidade presente, mesmo porque não geraram qualquer prejuízo concreto à Defesa, sobretudo quando "atualmente, até em casos de nulidade absoluta, doutrina e jurisprudência têm exigido a comprovação de prejuízo para que a mácula possa ser reconhecida". Arguição inicial que se rejeita. Segunda articulação do Writ, veiculando alegação de desnecessidade da prisão que, no entanto, merece acolhida. Provimento monocrático liberatório que foi antecipado pelo novo

169 TJ/RJ, APL n. 00126122520158190006, Rel. Sidney Rosa da Silva, Sétima Câmara Criminal, Rio de Janeiro, 9 set. 2016 - Grifos Nossos. 
Desembargador-Relator, em caráter superveniente ao exame da liminar, considerando não apenas as razões jurídico-factuais dispostas no presente voto, mas também os entraves registrados no e-doc 044. Crime (supostamente) praticado sem o viés da violência ou da grave ameaça, com arrecadação de pouca quantidade de entorpecente ( $32 \mathrm{~g}$ de maconha) e sem evidências, sérias e seguras, de vinculação do agente a qualquer facção criminosa. Paciente tecnicamente primário e de bons antecedentes. Ausência dos requisitos do Art. 312 do CPP. Substrato jurídico-factual da espécie concreta que, à míngua de qualquer peculiaridade concreta, não reclama a providência excepcional da segregação cautelar. Princípio da homogeneidade que, como regra, modula responsavelmente o cabimento da custódia preventiva. Orientação do STJ enaltecendo que "a prisão provisória é medida odiosa, reservada para os casos de absoluta imprescindibilidade, demonstrados os pressupostos da cautelaridade, respeitada a homogeneidade, proporcionalidade e adequação". Constrangimento ilegal que se remedia, sem prejuízo da adoção de eventuais cautelares alternativas, desde que cabíveis e necessárias, a cargo do Juízo a quo. Concessão parcial da ordem, consolidando-se o provimento liberatório expedido no e-doc $044^{170}$.

\subsubsection{Consequência jurídica da não realização da Audiência de Custódia}

A discussão sobre a consequência da não realização da apresentação do preso se destaca na temática da Audiência de Custódia.

A Resolução $n^{\circ} 213$ emanada pelo CNJ confere o caráter obrigatório da realização da audiência, contudo, não prevê nenhuma sansão para a não realização da apresentação do preso ao juiz competente.

Segundo as sábias palavras do jurista Orlando Faccini Neto:

(...) se disser que a não realização da audiência de custodia nenhum efeito produz, estar-se-á a compactuar com o risco de que simplesmente não ocorra; se se disser que a audiência implicará uma qualquer nulidade, ou a potencial determinação de soltura do preso, então isso é inegavelmente uma matéria de Direito Processual, que como tal, submete-se à reserva legislativa ${ }^{171}$.

Diante a inexistência de uma lei regulamentando o tema, recorre-se a jurisprudência para esclarecer qual a consequência jurídica vem sendo aplicada nos casos em que não se observa a realização da Audiência de Custódia.

170 TJ/RJ, HC n. 0008099-95.2016.8.19.0000, Rel. Carlos Eduardo Freire Roboredo, Terceira Câmara Criminal, Rio de Janeiro, 19 abr. 2016 - Grifos Nossos.

${ }^{171}$ PAIVA, 2016, p. 170. 
Apesar de não ser ponto pacífico na jurisprudência, os Tribunais de Justiça do Rio de Janeiro ${ }^{172}$, do Rio Grande do Sul ${ }^{173}$ e Goiás ${ }^{174}$, em decisões recentes, se manifestaram no sentido de que a não realização da Audiência de Custódia não tem condão para tornar ilegal a prisão preventiva convertida a partir do Auto de Prisão em Flagrante.

O entendimento de que a inobservância da Audiência de Custódia não torna ilegal a prisão cautelar é consolidada também em decisões recentes do STJ.

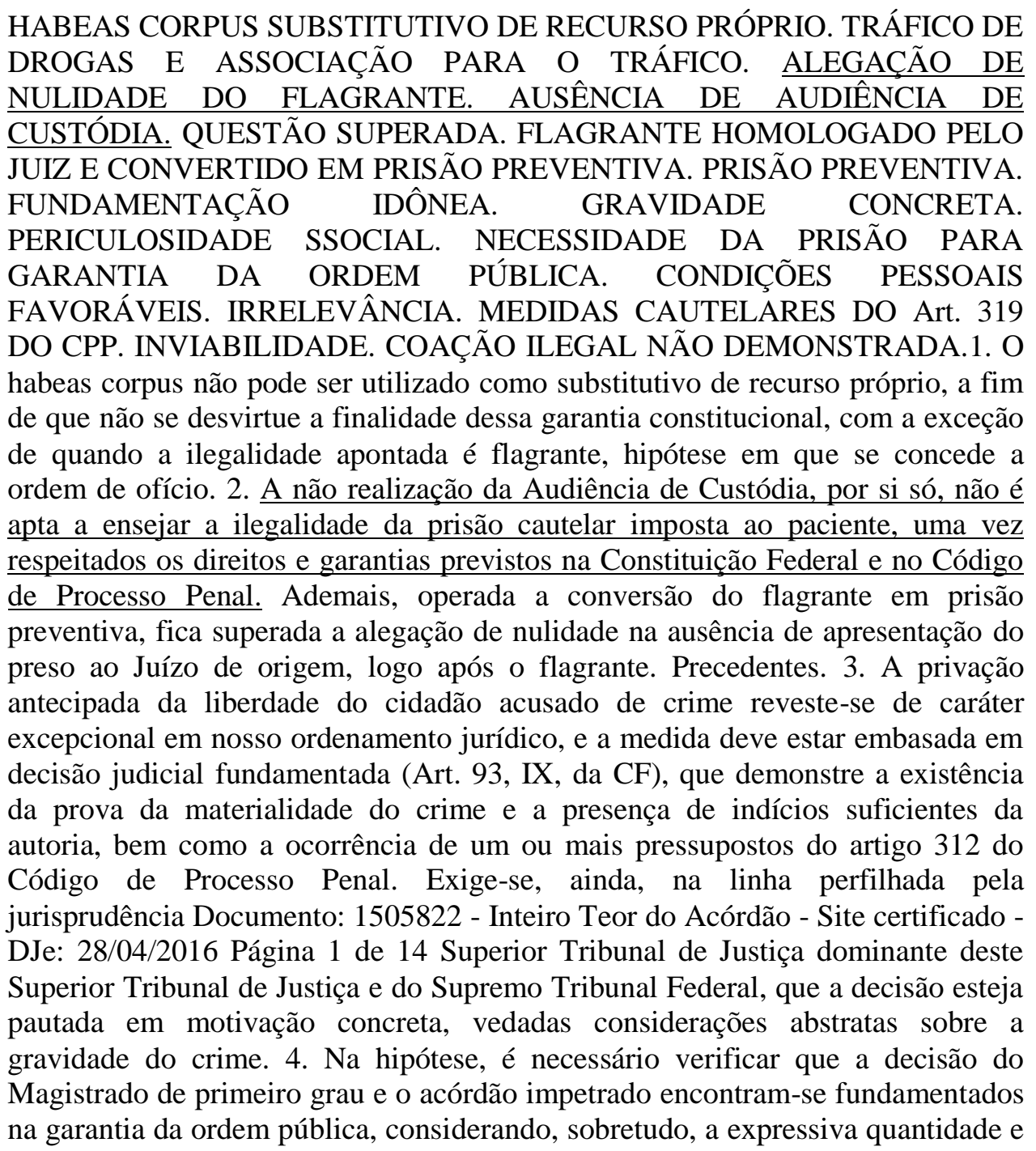

172 TJ/RJ, HC n. 00259955420168190000, Rel. Adriana Lopes Moutinho, Oitava Câmara Criminal, Rio de Janeiro, 22 jun. 2016.

${ }^{173}$ TJ/RS, HC n. 70069397685, Rel. Naele Ochoa Piazzeta, Oitava Câmara Criminal, Rio Grande do Sul, 25 mai.2016.

${ }^{174}$ TJ/GO, HC n. 02120603920168090000, Rel. Fernando de Castro Mesquita, Segunda Câmara Criminal, Goiás, 7 jul.2016. 
variedade das drogas apreendidas - 321,8 g de maconha, distribuídas em 253 sacos plásticos, 570,85 gramas de cocaína, acondicionados em 640 frascos do tipo eppendorf e 130,5 g de crack, divididos em 435 invólucros plásticos -, circunstâncias essas que evidenciam a gravidade da conduta perpetrada e a periculosidade social do acusado, justificando-se, nesse contexto, a segregação cautelar como forma de resguardar a ordem pública. 5. Eventuais condições subjetivas favoráveis ao paciente, tais como primariedade, bons antecedentes e residência fixa, por si sós, não obstam a segregação cautelar, quando presentes os requisitos legais para a decretação da prisão preventiva. Precedentes. 6. Mostra-se indevida a aplicação de medidas cautelares diversas da prisão, quando a segregação encontra-se fundada na gravidade concreta do delito, indicando que as providências menos gravosas seriam insuficientes para acautelar a ordem pública 7. Habeas corpus não conhecido. ${ }^{175}$

RECURSO EM HABEAS CORPUS. TRÁFICO, ASSOCIAÇÃO PARA O TRÁFICO E POSSE ILEGAL DE ARMA DE FOGO DE USO RESTRITO. AUDIÊNCIA DE CUSTÓDIA NÃO REALIZADA. AUSÊNCIA DE ILEGALIDADE. PRISÃO PREVENTIVA. FUNDAMENTAÇÃO IDÔNEA. CONSTRANGIMENTO ILEGAL NÃO CONFIGURADO. 1. A não realização de Audiência de Custódia não é suficiente, por si só, para ensejar a nulidade da prisão preventiva, quando evidenciada a observância das garantias processuais e constitucionais. Precedentes 2 . É legítima a prisão cautelar decretada com o fim de garantir a ordem pública, dada a gravidade concreta da ação. 3. Na espécie, a manutenção da prisão preventiva do recorrente justifica-se ante as circunstâncias em que ocorreu o flagrante dos três envolvidos, com a apreensão de duas variedades de entorpecentes (maconha e cocaína) e de artefatos bélicos de alto poder letal (4 fuzis, acessórios e munições), além de 2 rádios de comunicação, 13 baterias para os citados rádios e 3 cadernos de anotações. Tudo a revelar a periculosidade real do recorrente e a intensa ligação com a atividade ilícita de narcotraficância. 4. Recurso em habeas corpus improvido ${ }^{176}$.

Em suma, por tratar-se de tema ainda recente e oscilante na jurisprudência, evidencia-se o caráter emergencial da aprovação de uma lei que regulamente o procedimento da Audiência de Custódia e a consequência jurídica a ser aplicada diante a não realização da audiência.

\subsection{Críticas e dificuldades de implementação}

Por inexistir padronização no procedimento da Audiência de Custódia entre os estados brasileiros, abordaremos ${ }^{177}$ as críticas e as

\footnotetext{
175 STJ, HC n. 344989/RJ, Rel. Ministro Reynaldo Soares da Fonseca, Quinta Turma, Brasília, 19 abr. 2016 - Grifos Nossos.

${ }^{176}$ STJ, HC n. 69680/RJ, Rel. Ministro Sebastião Reis Junior, Sexta Turma, Brasília, 16 ago. 2016 - Grifos Nossos.

177 Todas as informações descritas no presente subcapítulo foram obtidas nas Palestras realizadas pela Defensoria Pública do Estado do Rio de Janeiro no dia 20 de outubro às 14 horas denominada
} 
dificuldade de implementação do instituto a partir de um panorama global acerca da realidade prática das referidas audiências no Brasil.

\subsubsection{Interiorização do projeto}

Segundo as informações ${ }^{178}$ do $\mathrm{CNJ}$, o projeto da Audiência de Custódia se encontra implantado nas capitais dos 27 estados da Federação, tanto no âmbito estadual quanto no federal.

Apesar do previsto no Art. $14^{179}$ e Art. $15^{180}$ da Resolução no 213 do CNJ, a interiorização do projeto não é uma realidade e poucos são os estados que realizam as Audiências de Custódia em outras comarcas distintas da Capital. Na maioria dos casos, a realização das audiências nas outras regiões parte da iniciativa de alguns (raros) juízes individualmente.

O estado da Bahia, por exemplo, é uma exceção à regra uma vez que opera as audiências em outras comarcas além da Capital.

Panorama Nacional das Audiências de Custódias - dinâmica com representantes das Defensorias Públicas Estaduais e da União que atuam na Audiência de Custódia mediada pelo Coordenador Criminal e de Execução Penal da DP/BA Maurício Saporito e pela Coordenadora do Núcleo de Audiência de Custódia da DP/RJ; no dia 21 de outubro às 10 horas denominada Audiências de Custódia: Olhar da Sociedade Civil presidida pelo Coordenador de Defesa Criminal Emanuel Queiroz Rangel e que possuía como palestrantes a Delegada no Brasil da Associação para Prevenção da Tortura Sylvia Dias, o Diretor para a América Latina da Open Society Foundations Pedro Abramovay e a Professora de Direito Constitucional e Teoria Geral do Processo da PUC/RJ autora da obra Discursos Negros: legislação penal, política criminal e racismo Thula Pires; no dia 21 de outubro as 14:30 horas a palestra denomina Um Ano de Audiências de Custódia no Rio de Janeiro - apresentação do relatório da Defensoria Pública presidida pelo Defensor Público Geral do Estado do Rio de Janeiro, André Castro, pelo Ministro do Supremo Tribunal Federal, idealizador do Projeto Audiencia de Custódia enquanto Presidente do Conselho Nacional de Justiça Enrique Ricardo Lewandowski, Juíza auxiliar da Presidencia do Tribunal de Justiça do Estado do Rio de Janeiro Maria Tereza Donatti e Diretora de Pesquisa da Defensoria Pública do Estado do Rio de Janeiro Carolina Dzimidas Haber.

${ }^{178}$ CNJ. Dados Estatísticos / Mapa de Implantação. Disponível em:

<http://www.cnj.jus.br/noticias/cnj/80804-primeira-audiencia-de-custodia-da-justica-federal-seraem-foz-do-iguacu-2>. Acesso em: 29 out. 2016.

${ }^{179}$ Art. 14. Os tribunais expedirão os atos necessários e auxiliarão os juízes no cumprimento desta Resolução, em consideração à realidade local, podendo realizar os convênios e gestões necessárias ao seu pleno cumprimento.

${ }^{180}$ Art. 15. Os Tribunais de Justiça e os Tribunais Regionais Federais terão o prazo de 90 dias, contados a partir da entrada em vigor desta Resolução, para implantar a Audiência de Custódia no âmbito de suas respectivas jurisdições. 
De fato, as comarcas interioranas enfrentam dificuldades com o número reduzido de servidores públicos, juízes, policiais e menores orçamentos, que se tornam obstáculos para a plenitude da implantação do projeto conforme almeja a Resolução.

Além disso, não podemos ignorar a realidade geográfica brasileira quanto a sua extensão territorial. No Amazonas por exemplo, somente é realizada Audiência de Custódia na comarca da Capital e a extensão do projeto para o interior é uma questão delicada pois o acesso a muitas regiões interioranas é restrito, somente sendo viável através de barcos o que dificulta o deslocamento de juízes, defensores e promotores para a realização diária dessas audiências.

\subsubsection{Realização diária das Audiências de Custódia}

Como já dito anteriormente, somente há a realização das Audiência de Custódia no Rio de Janeiro nos dias úteis até às $17 \mathrm{~h}$. Se o indivíduo é preso após às $17 \mathrm{~h}$ de uma sexta-feira, o seu auto de prisão em flagrante é analisado pelo Plantão Judiciário, e, se o juiz plantonista deliberar pela manutenção da prisão, o custodiado deverá aguardar até o próximo dia útil. Caso no plantão seja concedida a sua liberdade provisória, o custodiado é posto em liberdade e não participará da Audiência de Custódia.

A Audiência de Custódia consiste na apresentação do preso a uma autoridade judiciaria o mais rápido possível. A não realização das audiências nos dias não-uteis é incompatível com sua finalidade, além de atentar contra a dignidade da pessoa humana e contrariar a Resolução $n^{\circ}$ 213 do $\mathrm{CNJ}$ e os tratados internacionais que preveem as suas diretrizes. Feriados prolongados como o Carnaval, por exemplo, importam o confinamento dos custodiados por dias enquanto aguardam a condução para o seu primeiro contato com a autoridade judiciaria. 
É de suma importância que os Tribunais de Justiça dos Estados que não realizam as Audiências de Custódias diariamente tomem as providências necessárias para que tais medidas sejam cumpridas.

Os estados da Paraíba, Rondônia e Goiás, por exemplo, não cumprem o prazo para a realização da Audiência de Custódia em 24 horas após a prisão em flagrante de um custodiado, se esta ocorrer em dias não uteis. Já no Rio Grande do Norte, na Bahia e no Amazonas há a realização das Audiências de Custódia, na capital dos estados, todos os dias.

\subsubsection{Algemas}

Contrariamente ao previsto no Art 8, II $^{181}$ da Resolução do CNJ e da Súmula Vinculante $11^{182}$ do STF, no Rio de Janeiro os custodiados se encontram algemados durante a apresentação física com o juiz, independente de haver resistência ou fundado receio de perigo.

Infelizmente o uso das algemas durante a Audiência de Custódia não são a excepcionalidade e sim, a regra.

O uso de algemas associada a presença de um policial na sala de audiência propiciam um ambiente intimidador e, em razão disso, muitos presos se sentem inibidos e não relatam os maus tratos que sofreram em sede policial.

\footnotetext{
181 Art. $8^{\circ} \mathrm{Na}$ Audiência de Custódia, a autoridade judicial entrevistará a pessoa presa em flagrante, devendo:

II - assegurar que a pessoa presa não esteja algemada, salvo em casos de resistência e de fundado receio de fuga ou de perigo à integridade física própria ou alheia, devendo a excepcionalidade ser justificada por escrito;

${ }^{182}$ Súmula Vinculante 11:

Só é lícito o uso de algemas em casos de resistência e de fundado receio de fuga ou de perigo à integridade física própria ou alheia, por parte do preso ou de terceiros, justificada a excepcionalidade por escrito, sob pena de responsabilidade disciplinar, civil e penal do agente ou da autoridade e de nulidade da prisão ou do ato processual a que se refere, sem prejuízo da responsabilidade civil do Estado.
} 
Esta pratica corriqueira do uso de algemas deve ser aniquilada e somente deverá ser utilizada nos casos em que se demonstre fundado perigo de fuga ou perigo a integridade física própria ou alheia.

\subsubsection{Estrutura médica e multidisciplinar}

Nem todos os Tribunais de Justiça que aderiram ao Projeto da Audiências de Custódia disponibilizaram uma equipe médica prévia e multidisciplinar aos custodiados.

Como já dito anteriormente, a Central de Audiência de Custódia do Estado do Rio de Janeiro conta com o auxílio de uma psicóloga e de uma assistente social que atendem os custodiados que foram postos em liberdade encaminhando-os para uma rede de tratamento especializado de acordo com suas necessidades. Muitos custodiados são pessoas moradoras de rua, dependentes químicos, portadores de doenças mentais que precisam de ajuda.

Além disso, a Central de Audiência de Custodia localizada no Tribunal de Justiça do Estado do Rio de Janeiro disponibiliza uma equipe médica os custodiados que chegam lesionados ao local, seja em razão dos maus-tratos praticados pela população ou pelos próprios policiais.

O viés humanitário e social da Central da Audiência de Custódia no Rio de Janeiro materializa o fim a que propõem o Projeto idealizado pelo CNJ, que são a redução do encarceramento em massa e a reinserção daqueles que cometem pequenos delitos na sociedade.

\subsubsection{Inércia do Poder Legislativo}

Não há mais o que se discutir acerca da incorporação das diretrizes da Audiência de Custódia na legislação interna brasileira com a ratificação dos tratados internacionais pelo país em 1992. Isso, porém, não exime o 
Poder Legislativo de editar uma lei que padronize o procedimento da apresentação pessoal do preso em todo o território nacional.

A ausência de uma lei que padronize o procedimento da Audiência de Custódia gera tratamento e condições diferenciadas para os presos em flagrante de acordo com o estado da Federação em que a prisão é efetuada.

A jurisprudência vem se manifestando no sentindo de que a não realização da Audiência de Custódia não tem condão para tornar ilegal a prisão preventiva convertida a partir do APF, em razão da inexistência de uma lei regulamentando o instituto (princípio da legalidade). O código de processo penal apenas prevê que em até 24 horas será encaminhado o auto de prisão em flagrante para o juiz logo, basta que seja cumprida esta formalidade para que a convolação em prisão preventiva seja considerada legal, independente da realização da Audiência de Custódia.

Além disso, conforme leciona o jurista Orlando Faccini Neto ${ }^{183}$ :

Quanto mais padronizados os procedimentos, melhor fluidez encontrará o andamento das audiências, e mais segurança, para a sua atuação, terão os diversos profissionais envolvidos, como sejam policias, servidores da administração penitenciaria e funcionários do Poder Judiciário.

\subsubsection{Deficiência na apuração dos relatos de tortura}

A Audiência de Custódia possui um grande potencial inibidor da pratica de tortura e maus tratos, sendo um instrumento importante para mudar um paradigma cultural de aceitação de atos de violência na atuação policial.

O Relatório Anual Sobre o Perfil dos Réus Atendidos na Audiência de Custódia ${ }^{184}$ realizado pela Defensoria Pública do Estado do Rio de

\footnotetext{
183 PAIVA, 2016, p. 177.

${ }^{184}$ Defensoria Pública do Estado do Rio de Janeiro. Relatório sobre o perfil dos réus atendidos nas audiências de custódias. Disponível em:
} 
Janeiro demonstra que das 5.302 audiências realizadas, apenas 134 (4,37\%) custodiados alegaram terem sido vítimas de tortura.

Há, porém, uma grande dificuldade em se chegar a um número real dos casos de custodiados que sofreram violências em sede policial por vários motivos, entre eles o temor dos custodiados de sofrerem retaliações por parte dos policias em razão das denúncias, da dificuldade em se definir o que de fato seria "tortura" e a não relevância dada a estas apurações por parte dos magistrados.

A Audiência de Custódia é o momento propício para que sejam apurados eventuais indícios de prática de tortura e maus-tratos por parte dos policias desde o momento da prisão até o encaminhamento dos custodiados a audiência. Além da tortura, relatos de tratamentos cruéis como violência psicológica, ameaça, lesão corporal, extorsão também devem ser apurados.

O Protocolo II da Resolução 213 do CNJ prevê que o relato de maus tratos deve ser registrado em ata, deve haver o registro fotográfico das lesões evidentes, deve o custodiado ser encaminhado para exame de corpo de delito e que sejam enviados ofícios dos relatos para os órgãos responsáveis pela apuração de responsabilidades como o Ministério Público. Além disso, deve o juiz da instrução e julgamento ser notificado sobre os encaminhamentos e as informações advindas deste procedimento.

A Audiência de Custódia é o meio de se apurar os indícios de tortura e maus tratos e encaminhar os relatos aos órgãos competentes para investigar e aplicar as sanções de responsabilização dos policias. Uma das grandes dificuldades enfrentadas hoje em dia é com relação a inexistência de um instrumento que monitore estes órgãos e acompanhe o procedimento de investigação após os relatos.

<http://www.defensoria.rj.def.br/uploads/arquivos/dd58e4893bff4e7bbe1d862c6f06805a.pdf>. Acesso em 22 out. 2016. 
Partindo-se da premissa de que o juiz da Audiência de Custódia envie para o órgão competente um documento que contenha o relato do custodio acerca de violências sofridas em sede policial, é necessário que este órgão apure as denúncias e tome providências contra estes policias.

Não se pode permitir que os relatos de tortura apenas constem na ata da Audiência de Custódia. É necessário que ocorra de fato uma investigação e uma possível responsabilização dos "maus policiais" para que se possa aniquilar, de uma vez por todas, a cultura da aceitação dos atos de violência por parte dos policias.

\subsubsection{Perfil social dos custodiados}

O Relatório Anula Sobre o Perfil dos Réus Atendidos na Audiência de Custódia ${ }^{185}$ realizado pela Defensoria Pública do Estado do Rio de Janeiro demonstra que do total de 199 custodiados entrevistados, 138 se consideravam negros/pardos, 150 estavam na faixa etária entre 18 e 31 anos, apenas 38 presos declaram que possuíam ensino médio completo e 164 custodiados afirmaram que trabalhavam antes de terem sido presos (na maioria trabalhos informais como ambulantes e frentistas).

Os dados fornecidos desmistificam o discurso da impunidade. $\mathrm{O}$ rigor punitivo estatal está direcionado rigorosamente aos assistidos da Defensoria Pública por exemplo (negro, pobre, de baixa escolaridade).

O discurso da impunidade que sustenta a cultura do encarceramento e legitima o recrudescimento do Poder Punitivo, oculta uma política odiosa voltada contra uma origem social e racial específica.

185 Relatório sobre o perfil dos réus atendidos nas audiências de custódias. Acesso em 22 out. 2016. 
Mais uma vez ressalta-se que prisão não pode ser confundida com política pública. Em uma década, o Brasil dobrou ${ }^{186}$ o número de pessoas encarceradas alcançando o quarto lugar dos países que mais prende no mundo e mesmo assim possui índices altíssimos de violência.

\subsubsection{Resistência social e midiática quanto a implementação da Audiência de Custódia}

Apesar da Audiência de Custódia estar presente em tratados internacionais de direitos humanos ratificados pelo Brasil, de maneira voluntária e a mais de duas décadas, ainda existe muita resistência quanto a implementação dessas audiências no país.

Em defesa do discurso da impunidade que legitima o Poder Punitivo Estatal, críticas severas foram feitas às Audiência de Custódia por parte da mídia. Aqueles que associam o recrudescimento do Poder de Polícia Estatal como a única solução para os altos índices de violência urbana, sustentam que as Audiências de Custódia são prejudiciais à sociedade pois objetivam "colocar nas ruas os bandidos perigosos".

Com relação ao discurso incorporado pela mídia, os dados fornecidos pela Defensoria Pública do Estado do Rio de Janeiro através do Relatório $^{187}$ Anual Sobre o Perfil dos Réus Atendidos na Audiência de Custódia constam que das 5302 audiências realizadas no estado, apenas $2,8 \%$ dos custodiados retornaram a reincidir. Ou seja, o índice de reincidência dos custodiados que foram beneficiados com o instituto da liberdade provisória na audiência é ínfimo, o que desmistifica a ideia, equivocada, de que as Audiências de Custódia são maléficas a população

\footnotetext{
${ }^{186}$ Disponível em: <http://www.cnj.jus.br/files/conteudo/arquivo/2016/02/b948337bc7690673a39cb5cdb10994f8.pdf $>$. Acesso em 22 out. 2016.

${ }^{187}$ Relatório sobre o perfil dos réus atendidos nas audiências de custódias. Acesso em 22 out. 2016.
} 
uma vez que a põem em risco concedendo a liberdade aos "bandidos perigosos".

\subsubsection{O papel do juiz}

A Audiência de Custódia , como já dito anteriormente, obedece a uma tripla finalidade: a) analise da legalidade da prisão, de modo a evitar detenções arbitrárias; b) detectar eventuais ocorrências da pratica de tortura e maus tratos contra os detidos em sede policial, com o fito de evitar a ocorrência de violências realizadas por agentes do estado e c) apreciação sobre a possibilidade do conduzido responder ao processo criminal em liberdade, com ou sem medidas cautelares, ou da real necessidade/adequação/proporcionalidade da decretação da prisão preventiva.

O papel do juiz que preside a Audiência de Custódia é de suma importância para o combate a tortura. É necessário que o juiz tenha em mente que o preso se encontra em um estado de vulnerabilidade naquele momento e o ambiente de uma sala de audiência com um policial presente, já é intimidador por si só. Por este motivo, é preciso que o magistrado questione precisamente o custodiado sobre todos os fatos ocorridos desde a apreensão policial até o encaminhamento para a audiência, para que se verifique eventuais ocorrências de tortura ou maus tratos por parte dos policias.

Outro grande obstáculo que se busca romper com a implementação deste instituto é a cultura do encarceramento na qual o Poder Judiciário e a sociedade se encontram inseridos. Por este motivo, afirma-se que o sucesso ou o fracasso da Audiência de Custódia dependerá da efetiva adequação do juiz ao propósito do instituto, qual seja a decretação da prisão cautelar somente como última ratio. 
Em contradição com os padrões democráticos instituídos pela Constituição Federal, a prisão cautelar não é mais considerada uma medida excepcional ao passo em que qualquer motivo é suficiente para cercear o direito à liberdade de um indivíduo. O princípio da presunção de inocência é depreciado na chamada cultura da prisão compulsória na qual vivemos hoje.

Independente do fato de que possíveis medidas cautelares diversas ao cárcere se encontrem adequadas e eficientes ao caso concreto, os juízes optam pelo encarceramento, degenerando ainda mais o falido sistema carcerário no que tange a sua superlotação e falta de estrutura. Adeptos da cultura do encarceramento os magistrados, erroneamente, adotam a prisão cautelar como a primeira (e única) ratio a ser tomada, apesar das circunstâncias pessoais favoráveis ao caso concreto, como por exemplo o indivíduo primário de bons antecedentes que possui residência fixa e ocupação lícita.

A entrevista pessoal do juiz com o detido, ou seja, o "olhar no olho" do custodiado, "humaniza" a relação entre o magistrado e preso de modo a tornar a decisão mais eficiente quanto a concessão da liberdade provisória (quando presentes os requisitos), vez que exercer essa averiguação com base em um mero documento torna a decisão, na maioria das vezes, tendenciosa ao encarceramento.

Os questionamentos realizados nessa entrevista devem ater-se restritivamente a condições pessoais do indivíduo que demonstrem ser favoráveis a concessão da sua liberdade provisória, com ou sem a imposição de alguma medida cautelar diversa a prisão, como por exemplo a indagação da existência de residência fixa do detido em flagrante. A residência fixa, por exemplo, certifica que o indivíduo poderá ser encontrado neste local sempre que necessário para o processo ou para a instrução criminal, tornando, neste caso, a possibilidade de evasão genérica 
do réu como um argumento incoerente e arbitrário para a decretação da prisão preventiva.

Não se busca, na Audiência de Custódia, a produção antecipada de provas em desfavor do réu para a investigação criminal ou para a futura propositura da ação penal. $O$ magistrado deve impedir qualquer questionamento proferido pelo Ministério Público que vise este escopo como por exemplo, a indagação ao detido se ele praticou o delito.

Entretanto, conforme alerta o jurista Alexandre Rosa acerca da temática:

Parcela da magistratura está de "má vontade" na realização de ato exigido pela normativa internacional e, para tanto, tem se utilizado da Audiência de Custódia para finalidades em desconformidade com sua razão de ser (...) é a manipulação da finalidade da audiência, fazendo verdadeiro interrogatório, sem acusação formalizada. Confundem o ato de Audiência de Custódia com a produção antecipada de provas, em que se busca, não raras vezes, a confissão do conduzido. É a inversão da lógica do devido processo legal. Munidos de mentalidade inquisitória, buscam facilitar a instrução e eventual condenação, mediante perguntas sobre a conduta (...). Nesse caso, o material da audiência viola diversas garantias constitucionais e deveria ser declarado nulo (... $)^{188}$.

O instituto da Audiência de Custódia é de extrema importância para a reversão do quadro de superlotação do sistema carcerário contudo, somente terá eficácia se os magistrados romperem a cultura do encarceramento solidificando os preceitos democrático constitucionais. Assim, a liberdade do indivíduo será resguardada como a regra e a prisão cautelar, será vista como uma contingência excepcional aplicável somente quando se demonstrarem insuficientes a imposição de medidas cautelares diversas ao cárcere.

Em suma, o movimento de mudança cultural, partindo dos magistrados, é necessário para o sucesso da Audiência de Custódia. Nada

\footnotetext{
${ }^{188}$ ROSA, Alexandre Morais da. Quando o juiz manipula a Audiência de Custódia. Disponível em: $\quad<$ http://www.conjur.com.br/2016-jul-08/limite-penal-quando-juiz-manipula-audienciacustodia>. Acesso em: 22 out. 2016.
} 
adianta romper a chamada "fronteira do papel"189 por Ary Lopes Junior e Caio Paiva, se os juízes continuarem vinculando a prisão não como última ratio, mas sim como regra no sistema processual penal.

${ }^{189}$ LOPES; PAIVA, Audiência de Custódia e a imediata apresentação do preso ao juiz: Rumo à evolução civilizatória do processo penal. Acesso em: 28 out. 2016. 


\section{CONCLUSÃO}

Objetivou-se com o presente trabalho estimular o debate acerca do instituto jurídico da Audiência de Custódia em sua essência. Somente assim, explorando o instituto, ponderando as críticas e investigando as suas dificuldades de implementação, será possível identificar soluções futuras para que a apresentação pessoal do custodiado ao magistrado no prazo máximo de 24 horas seja uma realidade e um direito efetivo à todos os brasileiros.

O caráter democrático que a Audiência de Custódia intenta, advém da sua finalidade de trazer a pessoa do preso para o cenário do processo penal, humanizando a relação processual e proporcionando mais subsídios para que o juiz possa deliberar acerca da legalidade da prisão efetuada, da manutenção desta ou da liberdade da pessoa presa em flagrante. Antigamente esta deliberação ocorria com base, exclusivamente, através de um mero documento (APF).

A ideia advinda da Audiência de Custódia é substituir o sistema unidirecionado no qual o juiz deliberava sobre a liberdade de uma pessoa com base em um simples papel, tendendo a decisão ser favorável à manutenção da prisão em razão da cultura do encarceramento na qual a sociedade está inserida, para um sistema mais democrático e humano no qual o juiz toma esta decisão diante a pessoa presa sendo-lhe concedido o direito de ser ouvida.

Questões morais, sociológicas e a empatia do juiz com o custodiado diante a sua presença física no momento da decisão, são elementos que, segundo os idealizadores do Projeto da Audiência de Custódia, podem ajudar a reduzir o problema do grande encarceramento que o Brasil vive hoje muito em função da decretação imprópria da prisão preventiva. 
A cultura do encarceramento engrandecida pelo discurso da impunidade, associada ao desvio de finalidade do instituto da prisão preventiva e intimamente ligada a superlotação carcerária, reflete na posição que o Brasil assume como o $4^{\circ}$ país com a maior contingente de pessoas privadas de liberdade do mundo sendo que $41 \%$ dos presos são provisórios $^{190}$.

Assim, apesar da Audiência de Custódia ser idealizada pela doutrina como uma estratégia de combate ao crescimento da superpopulação carcerária a partir da humanização da relação juiz-custodiado, esta somente conseguirá atingir o seu propósito se houver uma mudança na ótica dos magistrados quanto ao rigor punitivista do Poder Judiciário.

Somente quando os juízes passarem a decretar a prisão cautelar nas ocasiões que efetivamente forem autorizadas pelas leis vigentes, respeitando os direitos constitucionais e fundamentais dos presos como o princípio da presunção de inocência, contraditório, ampla defesa e dignidade da pessoa humana e, principalmente, aniquilarem o inverídico e ilusório entendimento de que prisão é sinônimo de política pública de combate à violência, será possível que a Audiência de Custódia atinja o seu propósito de combate ao encarceramento em massa que vem ocorrendo no país.

Além disso, a Audiência de Custódia tem potencial para ser um recurso de combate eficaz e inibidor das práticas de tortura, maus-tratos e todos os tipos de violências praticados contra o preso na atuação policial. Pelo simples fato do policial saber que em 24 horas o custodiado vai ser apresentado fisicamente a uma autoridade judicial, já o intimida de praticar atos violentos contra o preso. Contudo, a Audiência de Custódia não será capaz de atingir a finalidade de combate a cultura da aceitação de práticas

\footnotetext{
190 INFOPEN, Levantamento Nacional de Informações Penitenciária. jun. 2014. Disponível em: <https://www.justica.gov.br/noticias/mj-divulgara-novo-relatorio-do-infopen-nesta-tercafeira/relatorio-depen-versao-web.pdf>. Acesso em: 15 ago. 2016.
} 
de violência contra o preso se os magistrados não se aprofundarem nas denúncias dos custodiados encaminhando-as para os órgãos competentes de verificação e responsabilização desses atos. Deve haver, inclusive, uma fiscalização mais rígida desses órgãos de modo a tornar efetiva a apuração e a responsabilização dos policiais infratores.

O Projeto da Audiência de Custódia trata-se de uma iniciativa que em 1 ano de implantação demonstrou grande êxito. Segundo dados ${ }^{191}$ fornecidos pelo CNJ foram realizadas em entorno de 93,4 mil Audiências de Custódias em todo o Brasil e 47,46\% destas resultaram na concessão da liberdade provisória dos custodiados. Isso significa que aproximadamente 44 mil custodiados deixaram de ingressar no sistema prisional desnecessariamente.

A Audiência de Custódia é uma conquista democrática que vem se demonstrando, segundo os resultados, triunfante quanto aos objetivos a que ela se propõe. Entretanto, é de suma importância que se identifique, se debata e que se analise as dificuldades de implementação das audiências na prática para que se possa cada vez mais aprimorá-las e atingir resultados mais notáveis e com maior efetividade.

Como já exposto no presente trabalho, o comprometimento dos juízes que presidem as Audiências de Custódia é primordial para que o Projeto logre com as suas finalidades. Todavia, deve haver mais eficiência quanto às fiscalizações dos meios de apuração e responsabilização dos policiais após os relatos da tortura, a expansão do Projeto para todas as regiões dos estados além da capital, as suas realizações diárias e o investimento em equipes multidisciplinares destinadas a realizar o acolhimento social quando necessário.

191 Disponível em: <http://www.cnj.jus.br/sistema-carcerario-e-execucao-penal/audiencia-decustodia/mapa-da-implantacao-da-audiencia-de-custodia-no-brasil>. Acesso em: 15 ago. 2016. 
Nem mesmo a visão mais otimista e próspera da implantação das Audiências de Custódias por todo o Brasil é capaz de afirmar que elas, unicamente, serão a solução para as mazelas do nosso sistema de justiça criminal quanto ao encarceramento em massa que vem ocorrendo no país. Todavia a iniciativa do Projeto da Audiência de Custódia advinda do próprio Poder Judiciário ( $\mathrm{CNJ})$, ao reconhecer a responsabilidade dos magistrados no cenário da superlotação do sistema penitenciário, demonstra ser um movimento louvável de esperança, otimismo e sensibilidade a partir do momento em que a pessoa presa passa ser vista, através do olhar do juiz, como um ser humano de direitos e não mais como um mero papel, em defesa dos direitos fundamentais constitucionais dos indivíduos que são (ou deveriam ser) os pilares de um Estado Democrático de Direito. 


\section{REFERÊNCIAS BIBLIOGRÁFICAS}

ABRAMOVAY, Pedro. Banalidade do réu: um dia de observação das audiências de custódia. Disponível em: <http://jota.info/banalidade-reuum-dia-de-observacao-das-audiencias-de-custodia>. Acesso em: 1 nov. 2016.

ANDRADE, Mauro Fonseca; ALFLEN, Pablo Rodrigo. Audiência de Custódia no Processo Penal Brasileiro. $2^{\mathrm{a}}$ ed. Porto Alegre: Livraria do Advogado, 2016.

CINTRA, Araújo, PELlEGRINI, Ada e DINAMARCO, Cândido. Teoria Geral do Processo. $3^{\mathrm{a}}$ ed. São Paulo: Revista dos Tribunais, 1981.

BECCARIA, Cesare. Dos delitos e das penas. $7^{\mathrm{a}}$ ed. Editora Martin Claret., 2003

BRASIL. Código 3 Em 1 Conjugados - Penal, Processo Penal e Constituição Federal. 12a ed., São Paulo: Editora Saraiva, 2016.

CANOTILHO, J.J.G. Direito constitucional. $6^{\mathbf{a}}$ ed. 1993.

Caso Acosta Calderón Vs. Ecuador. p. 26. Disponível em: <http://www.corteidh.or.cr/docs/casos/articulos/seriec_129_esp1.pdf>.

Acesso em: 20 ago.2016.

CNJ. Dados Estatísticos / Mapa de Implantação. Disponível em: $<$ http://www.cnj.jus.br/noticias/cnj/80804-primeira-audiencia-de-custodiada-justica-federal-sera-em-foz-do-iguacu-2>. Acesso em: 29 out. 2016.

COELHO, Edmundo Campos. A Oficina do Diabo: crise e conflitos no sistema penitenciário do Rio de Janeiro . Rio de Janeiro: Editora Espaço e Tempo LTDA; IUPERJ, 1987.

Constitución de Guatemala, Art. $6^{\circ}$. Disponível em: $<$ https://es.wikisource.org/wiki/Constituci\%C3\%B3n_de_Guatemala>. Acesso em: 22 ago.2016.

Defensoria Pública do Estado do Rio de Janeiro. Relatório sobre o perfil dos réus atendidos nas audiências de custódias. Disponível em: $<$ http://www.defensoria.rj.def.br/uploads/arquivos/dd58e4893bff4e7bbe1d8 62c6f06805a.pdf>. Acesso em: 22 out. 2016. 
Disponível em:

$<$ http://juris.cjcplp.org/portal/processo/verProcessoAndamento.asp?numero $=5448 \&$ classe $=$ ADI \&origem $=$ AP\&recurso $=0 \&$ tipoJulgamento $=\mathrm{M} />$. Acesso em: 2 set.2016.

Disponível em: <http://s.conjur.com.br/dl/adi-anamages-audienciascustodia.pdf $>$. Acesso em: 25 ago. 2016

Disponível em: <http://www.cnj.jus.br/noticias/cnj/82713-audiencias-decustodia-ja-evitaram-45-mil-prisoes-desnecessarias-2>. Acesso em: 25 ago. 2016

Disponível em: <http://www.cnj.jus.br/sistema-carcerario-e-execucaopenal/audiencia-de-custodia/mapa-da-implantacao-da-audiencia-decustodia-no-brasil>. Acesso em: 25 ago. 2016

Disponível em: <http://www.cnj.jus.br/sistema-carcerario-e-execucaopenal/contatos-dmf $>$. Acesso em: 2 set.2016.

Disponível em: <http://www.global.org.br/wpcontent/uploads/2016/03/Relatorio-Juan-Mendez-Espanhol-3.pdf>. Acesso em: 1 nov. 2016.

Disponível em: <http://www.gov.za/documents/constitution/ConstitutionRepublic-South-Africa-1996-1>. Acesso em: 22 ago. 2016.

Disponível em: <http://www.leychile.cl/Navegar?idNorma=176595>. Acesso em: 20 ago. 2016

Disponível em: <https://www.hrw.org/pt/news/2014/02/03/252627>. Acesso em: 1 nov. 2016.

Disponível em: <https://www.hrw.org/pt/news/2014/07/28/254675>. Acesso em: 1 nov. 2016.

Disponível em: <https://www.hrw.org/pt/news/2016/07/07/291657>. Acesso em: 1 nov. 2016.

Disponível em: <https://www.hrw.org/pt/sobre-human-rights-watch>. Acesso em: 1 nov. 2016.

Disponível em:

<http://www.cnj.jus.br/files/conteudo/arquivo/2016/02/b948337bc7690673 a39cb5cdb10994f8.pdf>. Acesso em: 22 out.2016 
Disponível em:

<http://www.parlamento.pt/Legislacao/Paginas/ConstituicaoRepublicaPortu guesa.aspx>. Acesso em: 25 ago. 2016

Disponível em:

<http://www.secretariasenado.gov.co/senado/basedoc/ley_0906_2004_pr00

7.html\#297>. Acesso em: 25 ago. 2016

Disponível em:

$<$ http://www.senado.leg.br/atividade/rotinas/materia/getPDF.asp?t=172861

$\& \mathrm{tp}=1 \#$ Emenda10>. Acesso em: 25 ago. 2016

Disponível em:

<https://www.cidh.oas.org/basicos/portugues/d.Convencao_Americana_Rat if..htm>. Acesso em: 20 ago. 2016

Disponível em:

<https://www25.senado.leg.br/web/atividade/materias/-/materia/102115)>. Acesso em: 25 ago. 2016.

FERNANDES, Antonio Scarance. Processo Penal Constitucional. $3^{\text {a }}$ ed. Editora Revista dos Tribunais. 1999.

GASPARINI, Diógenes. Direito administrativo. São Paulo: Saraiva, 1995.

GOMES, Décio Alonso. (Des)Acelaração Processual: Abordagens sobre dromologia na busca do tempo razoável do Processo Penal. Rio de Janeiro: Editora Lumen Juris, 2007.

GRECO, Rogério. Curso de Direito Penal Parte e Geral. v. I. $15^{\mathrm{a}}$ ed. Niterói, Rio de Janeiro: Editora Impetus, 2013.

INFOPEN, Levantamento Nacional de Informações Penitenciária. jun. 2014. Disponível em: <https://www.justica.gov.br/noticias/mj-divulgaranovo-relatorio-do-infopen-nesta-terca-feira/relatorio-depen-versaoweb.pdf >. Acesso em: 15 ago.2016.

IPEA, Instituto de Pesquisa Econômica Aplicada. Relatório de Pesquisa: Reincidência no Brasil. 2015. Disponível em:

<http://www.cnj.jus.br/files/conteudo/destaques/arquivo/2015/07/572bba38 5357003379ffeb4c9aa1f0d9.pdf>. Acesso em: 24 ago. 2016.

JARDIM, Afranio Silva. Direito Processual Penal. $7^{\mathrm{a}}$ ed. Rio de Janeiro: Editora Forense, 1999. 
JESUS, Damásio E. de. Código de Processo Penal Anotado. $9^{\mathrm{a}}$ ed. v. tb. RT, 1995.

LENZA, Pedro. Direito Constitucional Esquematizado. 12a ed. Editora Saraiva, 2008.

LOPES, Aury Jr.; PAIVA, Caio. Audiência de Custódia e a imediata apresentação do preso ao juiz: Rumo à evolução civilizatória do processo penal. Disponível em:

<http://www.revistaliberdades.org.br/site/outrasEdicoes/outrasEdicoesExibi r.php?rcon_id=209>. Acesso em: 25 ago. 2016.

MAZZUOLI, Valerio de Oliveira. Curso de Direito Internacional Público. $4^{\mathrm{a}}$ ed. Editora Revista dos Tribunais, 2010.

NUCCI, Guilherme de Souza. Prisão e Liberdade. $4^{\mathrm{a}}$ ed. Rio de Janeiro: Editora Forense, 2014.

PAIVA, Caio et al.. Audiência de Custódia Comentários à Resolução 213 do Conselho Nacional de Justiça. $1^{\text {a }}$ ed. Porto Alegre: Livraria do Advogado, 2016.

PIMENTEL, Manoel Pedro. O crime e a pena na atualidade. 1983.

RANGEL, Paulo. Direito Processual Penal. $7^{\mathrm{a}}$ ed. Rio de Janeiro: Editora Lumen Juris, 2003.

ROSA, Alexandre Morais da. Quando o juiz manipula a Audiência de Custódia. Disponível em: <http://www.conjur.com.br/2016-jul-08/limitepenal-quando-juiz-manipula-audiencia-custodia>. Acesso em: 22 out. 2016.

SCHMIDT, Paulo Luiz et al.. Livro Digital - CNJ 10 Anos. 2015. p. 12. Disponível em:

<http://www.cnj.jus.br/files/conteudo/arquivo/2016/02/09dc279833367882

0c2c7d6ba61fc067.pdf>. Acesso em: 22 out. 2016

STF, ADI n. 5240/SP, Rel. Ministro Luiz Fux, Brasília, 20 ago. 2015.

STF, ADPF n. 347, Rel. Ministro Marco Aurélio, Brasília, 27 ago. 2015.

STF, HC n. 126.292. Rel. Ministro Teori Zavascki, Brasília, 17 fev. 2016.

STF, RE 466.343-1/SP, Rel. Ministro Gilmar Mendes, Brasília, 31 dez. 2008. 
STJ, HC n. 344989, Rel Ministro Reynaldo Soares da Fonseca, Brasília, 19 abr. 2016.

STJ, HC n. 69680, Rel Ministro Sebastião Reis Junior, Brasília, 16 ago. 2016.

TJ/GO, HC n. 02120603920168090000, Rel Fernando de Castro Mesquita, Goiás, 7 jul.2016.

TJ/RJ, APL n. 00126122520158190006, Rel. Sidney Rosa da Silva, Rio de Janeiro, 9 set. 2016.

TJ/RJ, HC n. 00080999520168190000, Rel. Carlos Eduardo Freire Roboredo, Rio de Janeiro, 19 abr. 2016.

TJ/RJ, HC n. 00259955420168190000, Rel. Adriana Lopes Moutinho, Rio de Janeiro, 22 jun. 2016.

TJ/RJ, HC n. 0064910-46.2014.8.19.0001, Rel. Luiz Noronha Dantas, Rio de Janeiro, 25 jan. 2016.

TJ/RS, HC n. 70069397685, Rel. Naele Ochoa Piazzeta, Rio Grande do Sul, 25 mai. 2016.

TORNAGHI, Hélio. Curso de Processo Penal. $7^{\text {a }}$ ed. v. 2. Saraiva, 1990.

TORNAGHI, Hélio. Instituições de Direito Processual Penal. $2^{\mathrm{a}}$ ed. v. II, São Paulo: Saraiva, 1997.

TRF2-RSP-2015/00031, 18 dez. 2015. 